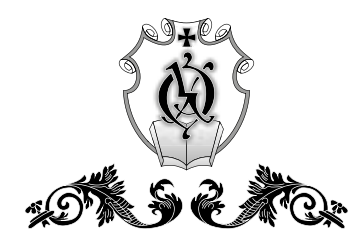

факультет міжнародних відносин

Кафедра країнознавства

\title{
МІЖНАРОДНІ \\ ВІДНОСИНИ І ТУРИЗМ: \\ СУЧАСНІСТЬ ТА РЕТРОСПЕКТИВА
}

Збірник матеріалів Десятої всеукраїнської науково-практичної конференџії студентів

та молодих учених

28 травня 2020 р., м. Острог

Випуск 10

Острог

Видавниџтво Наџіонального університету «Острозька академія» 2020 
Рекомендовано до друку радою факультету міжнародних відносин

Національного університету "Острозька академія"

(протокол № 13 від 24 червня 2020 року)

\section{Редакційна колегія:}

Олександра Фомін, Анастасія Заруцька, Олександра Януль.

\section{Рецензенти:}

Рудько С. О., кандидат історичних наук, доцент, завідувач кафедри країнознавства Національного університету «Острозька академія»;

Шишкін І. Г., кандидат історичних наук, доцент кафедри країнознавства Національного університету «Острозька академія».

Міжнародні відносини і туризм: сучасність та ретроспектива: збірник матеріалів Десятої всеукраїнської науково-практичної конференції студентів та молодих учених / ред. колегія: О. Фомін, А. Заруцька, О. Януль. Острог: Видавництво Національного університету «Острозька академія», 2020. Вип. 10. $98 \mathrm{c}$.

DOI $10.25264 / 24.06 .2020$

У збірнику розміщено матеріали Десятої всеукраїнської науково-практичної конференції студентів та молодих учених «Міжнародні відносини і туризм: сучасність та ретроспектива», що відбулася 28 травня 2020 року на базі Національного університету «Острозька академія».

Для науковців, аспірантів та студентів.

\section{УДК 001:327+379.5}

ББК 66

Роботи опубліковано в авторській редакиії.

Організачійний комітет не несе відповідальність за достовірність

статистичної інформації та інформаиії, щзо подана в рукописах.

(C) Видавництво Національного університету «Острозька академія», 2020

(C) Автори статей, 2020
СЕКція 1

АКТУАЛЬНІ ПРОБЛЕМИ ЗАРУБІંЖНОГО РЕГİОНОЗНАВСТВА 


\section{Анастасія Мартинюк,}

студентка 4 курсу

Національний університет «Острозька академія»

\section{БОРОТЬБА ЗА ГЕНАЕРНУ РІВНІСТЬ У ШВЕЦІЇ}

Королівство Швеція - одна з перших країн світу, що почала проводити свою зовнішню політику, як політику, що підтримує фемінізм. Основною метою цієї політики є сприяння рівності та повне забезпечення прав людини для всіх жінок. Виконання основних прав жінок є як обов'язком у рамках міжнародних зобов'язань, так і необхідною умовою досягнення ширших зовнішньополітичних цілей Швеції - миру, безпеки та сталого розвитку.

Вже тривалий період часу Швеція є видатним поборником за гендерну рівність як у країні, так і у світі в цілому, незалежно від політичної партії в уряді. Шведський закон про гендерну рівність було прийнято ще у 1979 році, для створення рівного ринку праці, вільного від дискримінації, а вже з 1994 року стало нормою, що половина міністрів є жінками. У 2020 році буде відзначатися 20-та річниця першої Резолюції Ради Безпеки щодо «Жінок, миру та безпеки», де Швеція планує заохочувати жінок брати участь у виборах у всьому світі - як голосувати, так і балотуватися на посаду. Жіноче підприємництво отримає підтримку, і Швеція працюватиме над тим, щоб міжнародна торгівля була вигідною для жінок як виробників, підприємців, працівників та споживачів так само, як і чоловіків. У Міністерстві закордонних справ Швеції та урядових відомствах застосовуються також рекомендації щодо гендерної рівності. Все, починаючи зі звітування до найняття, повинно враховувати гендерну рівність. Як наслідок, у Швеції сьогодні понад 40 відсотків жінокглав представництв за кордоном, число яких було 10 відсотків 20 років тому [5].

Після загальних виборів 2014 року, коли соціал-демократичний прем'єр-міністр Стефан Левен визнав свій новоутворений уряд «феміністським», він підкреслив свій намір прискорити порядок денний гендерної рівності. Заявляючи про феміністичний уряд, Левен підкреслив, що гендерна рівність - це питання не до жінки, а до суспільства в цілому, в тому числі фінансово [3]. Відносини між чо- ловіками та жінками будуються соціально, і різноманітні бар'єри, які можуть заважати жінкам реалізувати свої права та потенціал, повинні бути максимально усунені. Таким чином в результаті можна досягти процвітання економіки, коли реалізується весь потенціал країни.

Перша «феміністська» зовнішня політика у світі народилася менше десятиліття назад. Задум МЗС Швеції Маргота Уальстрема «феміністська» зовнішня політика, була озвучена негайно на першій зустрічі новопризначеного міністра 3 дипломатичними працівниками Міністерства закордонних справ. Хоча визнання гендерної рівності було вже знайоме для Королівства Швеції, але політика була новою та сміливою. І невдовзі після цього формально була розпочата «феміністська» зовнішня політика, що існує й діє і до сьогодні [2].

Варто зазначити, що така зовнішня політика фемінізму не є заміною чи доповненням до зовнішньої політики. Йдеться про застосування перспективи гендерної рівності у всіх питаннях зовнішньої політики. Вона має просте обгрунтування: чоловіки та жінки разом становлять населення світу, і для досягнення стабільного миру, безпеки, розвитку та економічного зростання у світі, і чоловіки, і жінки повинні брати участь у формуванні світу, який ми поділяємо, також разом. Гендерна рівність і є ціллю та засобом досягнення інших загальних цілей, таких як мир, безпека та стійкий розвиток. На жаль, сьогодні досі існує ця дискримінація жінок на різних рівнях у всіх країнах світу. Сюди входить і Швеція, тому феміністська зовнішня політика також має внутрішню сестринську політику. Вони випливають із того, що шведський уряд також $є$ феміністським урядом, виходячи з мети, що і чоловіки, і жінки повинні мати однакові можливості для формування власного життя, а також свого суспільства [1].

Зовнішня політика феміністів - $\epsilon$ перспективою і методом, що спирається на «три стовпи», що починаються 3 літери R: Rights (права), Representation (представництво), Resources (ресурси):

Права: Шведська Служба закордонних справ сприятиме повному виконанню прав людини всіх жінок та дівчат шляхом боротьби 3 усіма формами насильства та дискримінації, що обмежують їхню свободу дій;

Представництво: Шведська Служба закордонних справ сприятиме участі та впливу жінок у процесах прийняття рішень на всіх рівнях та в усіх сферах та шукатиме діалогу з представниками жінок на всіх рівнях, включаючи громадянське суспільство.

(C) Анастасія Мартинюк,, 2020 
Ресурси: Шведська служба закордонних справ працює над тим, щоб розподіляти ресурси для сприяння гендерній рівності та рівним можливостям для всіх жінок та дівчат користуватися правами людини.

Існує також четвертий $\mathrm{R}$, який позначає, що дія повинна базуватися на Reality (реальності).

Реальність полягає в тому, що, попри незліченну кількість домовленостей, резолюцій та планів дій протягом останніх десятиліть, рівності жінок не досягнуто. Для ілюстрації, минуло понад 70 років 3 часу прийняття Загальної декларації прав людини, 40 років 3 часу прийняття Конвенції про ліквідацію всіх форм дискримінації щодо жінок (CEDAW), майже 25 років $з$ часу прийняття акції План Всесвітньої конференції $з$ питань жінок у Пекіні та майже 20 років 3 моменту прийняття першої резолюції Ради Безпеки ООН щодо жінок, миру та безпеки, та жінки досі не користуються рівними правами 3 чоловіками. Жінкам не дозволено представляти себе чи бачення майбутнього своїх країн у місцях, де приймаються такі рішення, i, нарешті, не виділяються ресурси для забезпечення прогресу жінок та дівчат. Це шкодить стійкому миру, безпеці та розвитку. Тому «феміністська» зовнішня політика є ключовою для більш інклюзивного та гендерно-рівного майбутнього [4].

\section{Список використаних джерел та літератури:}

1. Життя європейців: гендерна рівність в Швеції. Повага. 2014. URL: https://povaha.org.ua/amp/zhyttya-jevropejtsiv-henderna-rivnist-v-shvetsiji/

2. Feminism Comes to the Forefront of Swedish Politics. Time. 2014 URL: https://time.com/3319652/feminism-comes-to-the-forefront-ofswedish-politics/

3. Feministisk regering. Regeringskansliet. 2018. URL: https://www. regeringen.se/regeringens-politik/feministisk-regering/

4. SWEDEN'S FEMINIST FOREIGN POLICY ILLUSTRATED. TPQ 2019. URL: http://turkishpolicy.com/article/952/swedens-feminist-foreignpolicy-illustrated

5. The Swedish Foreign Service action plan for feminist foreign policy 2019-2022, including direction and measures for 2019. Government Offices of Sweden. 2018. URL: https://www.government.se/informationmaterial/2018/03/swedish-foreign-service-action-plan-for-feminist-foreignpolicy-20192022-including-indicative-measures-for-2019/

\section{Віктор Лазарчук,}

студент 4 курсу

Національний університет «Острозька академія»

\section{ВІАНОСИНИ ЄВРОПЕЙСЬКОГО СОЮЗУ ТА ШВЕЙЦАРСЬКОЇ КОНФЕАЕРАЦІї B YMOBAX BREXIT}

Відносини Європейського Союзу та Швейцарії є унікальними й специфічними, адже хоч Швейцарія не належить до Свросоюзу, відносини між обома сторонами є максимально інтегрованими. Вони передбачають свободу переміщення громадян, антидемпінгові заходи на ринку праці та доступ швейцарських товарів і компаній на європейський ринок без дискримінацій.

Дослідженням європейсько-швейцарських відносин займається низка закордонних вчених. Проте дослідженням відносин ЄС та Швейцарії Шарлотта Зібер-Гассер (Charlotte Sieber-Gasser) «Handels beziehungen Schweiz - EU im globalen Kontext» описує не тільки зміни, які принесе рамкова угода, а й чинники які впливають на відносини між Швейцарською Конфедерацією та ЄС, серед яких торгова війна між ЄС та США і та вихід Британії з Європейського Союзу (Brexit).

Та попри тісні зв'язки у відносинах між ними $є$ певні розбіжності. Особливо це стосується проблем підписання угоди InstA, що оновлює механізми їхніх відносин та проведення Швейцарією референдуму про обмеження трудової міграції для громадян Свросоюзу.

Процес Brexit тісно переплітається $з$ відносинами Швейцарії 3 Євросоюзом. Рішення Великобританії про вихід з СС має певні наслідки для Швейцарії, враховуючи те, що відносини між британцями та швейцарцями в основному будуються на двосторонніх угодах між Швейцарією та ЄС.

Великобританія є важливим партнером для Швейцарії з економічної, політичної та міграційної точки зору. Тому уряд Швейцарії уважно стежить за подіями навколо виходу Великобританії з Свропейського Союзу. Також країни об'єднує тиск з боку Свропейського Союзу стосовно подальших відносин. Для збереження стабільних відносин 3 Великобританією та їх можливого розширення феде-

(C) Віктор Лазарчук, 2020 
ральний уряд Швейцарії прийняв особливу стратегію під назвою «Mind the gap».

В рамках цієї стратегії Швейцарія ініціювала підписання перехідної угоди, що гарантує збереження ідентичних прав для громадян Великобританії, які були до виходу з СС. У 2019 році між країнами було підписано ще низку договорів, що зможуть регулювати відносини.

Вихід Великої Британії з Свропейського Союзу викликає значну стурбованість у швейцарських підприємців, адже Brexit безпосередньо впливає на сферу торгівлі у Швейцарії й деякі швейцарські компанії висловили свою позицію. Наприклад, представники найбільшого швейцарського та світового харчового концерну «Nestle» заявили, що сценарій «жорсткого Brexit» здатний створити низку ризиків для харчової промисловості. «Ми робимо ставку на подальший позитивний розвиток традиційних тісних зв'язків 3 партнерами не тільки з Великобританії, а й з СС. Така співпраця вигідна для всіх сторін, особливо в умовах вільної торгівлі. Для нас дуже важливо забезпечити нашим споживачам з Великобританії та інших європейських країн вільний доступ до нашої продукції, незалежно від того як будуть врегульовані політичні проблеми (Brexit)»- стверджують в компанії. А швейцарський банк Credit Suisse наголосив, що їх експерти проводять постійні консультації для того, щоб опрацювати всі можливі підходи розв'язання проблем. Як альтернативні центри концентрації європейської діяльності будуть розглядатися Мадрид, Франкфурт-на-Майні та Люксембург, проте Лондон все ж залишатиметься важливим центром для швейцарських фінансових інституцій навіть після Brexit.

Відносини Швейцарії та Євросоюзу безпосередньо впливали і на переговори стосовно Brexit. Як відомо, завдяки особливим білатеральним відносинам Швейцарія без безпосередньої інтеграції може безперешкодно користуватися усіма перевагами членства в $\mathrm{CC}$ і на переговорах щодо Brexit з Великобританією Брюссель відчайдушно уникав надання такої можливості для Великої Британії.

Біржова суперечка між Швейцарією та ЄС теж певним чином мала вплив на переговори стосовно виходу Великої Британії з Свросоюзу. В 1995 році у Швейцарії шляхом об'єднання женевської, цюрихської та базельської бірж створилася біржа SIX Swiss Exchange. Після визнання iii еквівалентності вона отримала спрощений доступ до європейських фінансових ринків. Швейцарський фондовий ринок є четвертим за величиною в Свропі після Великобританії, Франції та Німеччини. Але у 2017 році Європейський Союз поси- лив тиск на Берн стосовно підписання рамкової угоди, що регулює ïx двосторонні відносини. Тому він заявив, що буде визнавати еквівалентність швейцарського біржового права лише рік. Уряд Швейцарії вважає, що ЄС намагається послабити позиції Конфедерації як фінансового центру і тому у відповідь на «незрозумілі» дії щодо закінчення терміну еквівалентності з першого липня 2019 року заборонив торгівлю швейцарськими акціями на європейських біржах.

Через це серед громадян Швейцарії почала поширюватися думка, що уже і так напружені відносини з Свросоюзом почали погіршуватися саме через Brexit. Вони вважають, що СС спеціально тисне на Швейцарію, аби показати Великій Британії, що отримати особливі відносини та переваги від членства в Європейському Союзі не являючись його членом дуже важко через принциповість СС. В самому Євросоюзі таку думку, відкидають. Канцлерка ФРН навіть заявила, що переговори зі швейцарцями повинні вестися так, ніби питання Великобританії ніколи не існувало.

Велика Британія пильно спостерігала за цим процесом, адже іiі уряд вважав, що СС цілком реально може використовувати еквівалентність як об'єкт маніпуляції в переговорах. Колишній прем'єрміністр Великої Британії Тереза Мей запропонувала розв'язання цієї проблеми створюючи режим співпраці з СС під назвою «еквівалентність плюс», що дозволив би біржам функціонувати в нормальному режимі протягом двох років після Brexit. Але в уряді цю ініціативу не підтримали й відклали ії прийняття на невідомий термін.

Швейцарія також планує взяти певні вигоди від виходу Великої Британії з Євросоюзу. Враховуючи складні відносини з Європейським Союзом після референдуму у 2014 році стосовно введення квот для трудових мігрантів і тимчасового зупинення Сврокомісією участі Швейцарії в наукових дослідженнях, уряд зацікавився в можливості спільного науково-технічного співробітництва $3 \mathrm{Be}-$ ликобританією. Також в уряді з'явилася ініціатива про заклики повторного вступу Британії до Європейської асоціації вільної торгівлі, яка об’єднує Швейцарію, Ісландію, Ліхтенштейн та Норвегію і була створена саме для конкуренції з Європейським економічним простором, аргументуючи це тим, що організація здобуде колишню силу і в Свропі знову з'явиться спілка, що прагне співпрацювати лише на економічному рівні. Проте британці впевнені, що можуть отримати більше можливостей, коли вони будуть діяти самостійно. ЄС теж висловив свою позицію стосовно перспектив приєднання Великобританії до САВТ. Представники Європейської Комісії з питань Brexit заявили, що Великобританія може тимчасово стати чле- 
ном САВТ під час перехідного періоду британсько-європейських відносин. Такий варіант часто називають «норвезькою моделлю», що дозволяє зберегти поточні торговельні зв'язки з Свропейським Союзом.

Отже, можна зробити висновок, що процес виходу Великобританії з Європейського Союзу мав вплив на відносини між Швейцарією та ЄС. Особливо це стосується питання рамкової угоди, що на думку самих швейцарців ускладнюється через прагнення Євросоюзу показати Британії свою принциповість і що дня них $є$ пріоритетом, а також це має безпосередній вплив на розвиток торговельних відносин.

Список використаних джерел та літератури:

1. Brexit. Segreteriadi Stato della migrazione. 2019. URL: https://www. sem.admin.ch/sem/it/home/themen/fza_schweiz-eu-efta/brexit.html

2. EU-Swiss trading dispute has Brexit implications, says Swiss stock exchange boss. CNBC. 2019. URL: https://www.cnbc.com/2019/09/09/euswiss-trading-dispute-could-repeat-for-brexit-britain-says-stock-exchangeboss.html

Свгеній Чопа,

студент 4 курсу

Національний університет «Острозька академія»

\section{ВПЛИВ АЕЗІНТЕГРАЦІЙНИХ ПРОЦЕСІВ В КАТАЛОНIÏ НА ВНУТРІШНЬОПОАІТИЧНУ СИТУАЦІЮ В КОРОАІВСТВІ ІСПАНІЯ}

На сучасній політичній карті світу все частіше можна спостерігати таке явище як динамічність інтеграційних та дезінтеграційних процесів у різних регіонах світу, що робить дослідження цієї теми актуальним у всьому геополітичному просторі.

Так як складовою теми наукової роботи $є$ вплив дезінтеграційних процесів в автономній області Каталонія, що знаходиться у Королівстві Іспанія, то коротко розглянемо поняття дезінтеграційних процесів у світі загалом та у даному макрорегіоні зокрема.

Оцінюючи стан наукових джерел та публікацій, що присвячені проблематиці дослідження, можемо зробити висновок про те, що стосовно дезінтеграції Каталонії теоретичних напрацювань відносно небагато, адже референдум про незалежність Каталонії відбувся лише 4 місяці тому. За цей час з'являлись публікації на різних новинних ресурсах України та всього світу. Для прикладу, для ознайомлення із ситуацією я використовував новинний ресурс «Deutsche Welle» та публікацію авторів Віктора Черецького та Наталії Мехед, новинні ресурси «Гордон» та «Еспресо TV». Також, досліджувати дану тему допомагали офіційні документи Женералітету Каталонії, що містять статистичні дані щодо економічної ситуації регіону, результатів проведення референдуму 1 вересня 2017 року та виборів в Каталонії 21 грудня 2017 року.

Термін «дезінтеграція» означає розпад цілого на частини. Для прикладу дезінтеграційні процеси стосуються як міжурядових організацій (ЄC та проведення Brexit), так і федеративних держав (Югославія, Чехословаччина), держав, які мають у своєму складі автономії (Сербія, Велика Британія, Італія) або є об'єктами територіальної експансії з боку сусідів (АР Крим). Наслідками дезінтеграційних процесів є припинення існування СФРЮ та СРСР, утворення нових незалежних держав - Словаччина, Чеська Республіка,

(с) Євгеній Чола, 2020 
Чорногорія або ж таких, незалежність яких визнано тільки невеликою кількістю суб'єктів міжнародних відносин (Північний Кіпр, Абхазія, Південна Осетія).

Фактори та передумови, що призводять до дезінтеграції певного регіону мають досить розгалужену класифікацію: етнічний, релігійний, економічний, політичний та інші. Що ж спонукає каталонців відокремитись від Королівства Іспанія? Насправді, передумов для цього $є$ достатня кількість. До політичних можна віднести репресії проти Каталонії в часи правління Філіпа V. 11 вересня 1714 року Іспанський король взяв штурмом та спалив Барселону, зруйнувавши половину торговельного кварталу. Також, було страчено значну кількість населення, заборонена каталанська мова, а вольності місцевої знаті разом із автономією Каталонії були анульовані [6].

Подібна ситуація мала місце в історії Каталонії за правління диктатора Франко. Знову ж таки, місто Барселона було зруйноване, з'явились репресії проти місцевої інтелігенції, а каталанська мова вкотре була заборонена.

Лише у 1979 році після демократизації режиму Каталонія отримує автономію, а згодом і визнання каталанської мови, що стало ключем до розгортання у майбутньому дезінтеграційних настроїв у цьому регіоні.

Якщо брати до уваги етнонаціональний чинник, то тут все доволі просто: наявність давньої історії, власної самостійної мови та специфічної культури, етнонаціональна ідентичність громадян та історичні конфлікти між іспанцями і каталонцями. Це є одні з найголовніших факторів, що дозволяють представникам цього народу об'єднатись для досягнення своєї цілі.

Але слід звернути увагу і на економічний чинник. За даними влади Каталонії цей регіон щорічно створює близько 19\% ВВП всієї країни, а частка Каталонії в іспанському експорті становить близько 26\%, що вказує на високий економічний розвиток цього регіону. Для того, щоб ще більше зрозуміти економічну міць регіону, варто вказати, що Каталонія - це лише 6,3\% всієї території Королівства Іспанія [2]. Перш за все, основний прибуток Каталонії приносить сфера послуг. Основним щаблем доходу є туризм. Щорічно Каталонія приймає майже 18 млн туристів зі всього світу, що приносить близько 16 млрд доларів до бюджету регіону. В столиці Каталонії Барселоні розташовані офіси всесвітньо-відомих компаній, таких як Microsoft, IBM, Nestle та інші. Також, щорічно у місті проводиться світовий форум - Mobile World Congress [5]. Зрозуміло, що регіон $\epsilon$ привабливим для світової спільноти і цей факт приносить Каталонії величезні прибутки. Але таку картину ми спостерігаємо, коли регіон $є$ частиною Іспанії. А що ж трапиться, коли автономія (на момент написання Каталонія зберігає статус автономії) перетвориться на самостійну державу?

Логічним буде висновок, що в перші роки після проголошення незалежності Каталонії, регіон втратить немало і стабілізувати економічну ситуацію виявиться нелегким завданням. Адже цілком ймовірно, що уже самостійний регіон перестане бути членом Світової організації торгівлі, що зіткне Каталонію зі значними економічними бар'єрами, що були відсутні до цього.

CNN Money пишуть, що навіть при збереженні Каталонією євро, як валюти, вона втрачає місце в Центральному європейському банку. Подорожчають товари, як імпортні, так і ті, що йдуть на експорт. Система накопичення пенсійного забезпечення дасть збій і громадяни можуть втратити свої накопичені пенсії.

Потік туристів в перші роки суттєво зменшиться, що напряму буде пов’ язано з валютою та можливою забороною Мадридом здійснювати рейси до барселонського аеропорту Ель-Прат, який щороку приймає 40 млн пасажирів [8].

Втрати Каталонії, насамперед економічні, дуже чітко зрозумілі. Але слід розібратись у тому, що чекає на Королівство Іспанія після здобуття автономією незалежності. Так, економічна ситуація в країні значно погіршиться, але зараз нас цікавить внутрішньополітична складова.

Там, де є дезінтеграційні процеси, виникає нестабільність, що зачіпає всі сфери життя країни: політичну, економічну, соціальну тощо. Хоча Мадрид і не визнає результатів референдуму 1 жовтня 2017 року та взагалі вважає його незаконним, це не завадить розгорнути подібні рухи в Андалусії та у Країні Басків. Слід розуміти, що у динамічному світі достатньо лише прецеденту, аби розгортання подібних ситуацій набирало обертів.

Варто зазначити, що жовтневий референдум 2017 року викликав резонанс у світової спільноти. Стрічки новин більшості ресурсів були заповнені новинами про Каталонію ще не один день після проведення запланованого голосування.

1 жовтня під час народного волевиявлення постраждало близько 844 осіб внаслідок жорсткого характеру дій з боку іспанської поліції, що виконувала вказівки Мадриду: блокувати виборчі округи, штучно знизити явку виборців, конфіскувати урни з бюлетенями. Переглядаючи відеоматеріали того дня, чітко видно, що поліція за- 
стосовувала дубинки, гумові кулі проти бажаючих висловити свою позицію.

Подібна поведінка Мадрида визвала осуд не тільки у президента Женералітету Каталонії Карлеса Пучдемона, а й з боку Бельгії в лиці прем’єр-міністра Шарля Мішеля, який вказав на те, що його країна засуджує усі види насилля і найкращим способом вирішити те чи інше питання - $є$ політичний діалог.

Засновник компанії WikiLeaks, Джуліан Асанж, взагалі призвав голову Єврокомісії призупинити членство Іспанії в ЄС, саме через ситуацію з референдумом, посилаючись на 2 статтю Лісабонського договору про дотримання прав людини, включаючи права осіб, які $\epsilon$ представниками національних меншин. Та на статтю 7, яка говорить про те, що до порушника статті 2 можуть бути прийняті міри [3].

При явці 43,03\% бажання відокремитись було присутнє у 90,18\% виборців [1]. Після чого парламент Каталонії 27 жовтня 2017 проголошує незалежність Республіки Каталонія. Це при тому фактові, що декількома днями раніше, а саме 21 жовтня влада Каталонії була відправлена у відставку. А 19 жовтня Мадрид почав процес анулювання статусу автономії згідно Конституції (1978), стаття 155.

Цілком прогнозованим було те, що Королівство Іспанія буде категорично не згідне з результатами референдуму, про що і заявив на офіційному рівні прем'єр-міністр Іспанії Маріано Рахой. Єврокомісія теж дала свій коментар з приводу цієї ситуації, заявивши, що питання про статус регіону - це внутрішньодержавне питання, що повинно вирішуватись згідно діючої конституції Королівства Іспанія [4].

Так як парламент Каталонії був розпущений, то Мадрид назначив дострокові вибори в Парламент на 21 грудня 2017 року [9]. Більшість голосів $(25,4 \%)$ отримала партія, яка підтримує статус Каталонії, як автономії, в складі єдиної Іспанії на чолі з Інес Арімадас. Але в цілому партії, що виступають за незалежність регіону набрали 47,5\% голосів, а виступаючі проти - 43,5\% голосів. Варто зазначити, що партія Карлеса Пучдемона зайняла друге місце на виборах 21 грудня, [7] незважаючи на те, що лідер на даний момент переховується у Бельгії.

Загальна ситуація показує нам, що уряд Королівства Іспанія побоюється можливого проголошення незалежності Каталонії і це небезпідставно. Страхи опинитись у нестабільній ситуації в економічній, політичній, соціальній сферах, та страхи «ефекту доміно», що стосується дезінтеграційних процесів в інших регіонах Іспанії спонукатимуть уряд робити конституційні зміни, що стосується централізації влади і можливого зменшення прав автономій або ж взагалі їх анулювання.

Але слід розуміти, що подібні кроки повинні бути зваженими i досить добре продуманими, адже для того, щоб активізувались певні радикальні групи в тому чи іншому регіоні, достатньо лише іскри. А масові заворушення на більшості території Іспанії зведуть нанівець всі намагання стабілізувати ситуацію, що стосується цілісності держави.

Варто розуміти, що ситуація, яка виникає в Іспанії $є$ не схожою, наприклад, з проголошенням незалежності Косово, що було автономним краєм Сербії, якщо вже шукати певні аналогії для того, щоб вирішити проблему. Адже ще з 988 року основною часткою населення Каталонії є саме каталонці, в той час як у Косово ще на початку другої половини XX століття частка сербського населення переважала над албанським, а на збільшення албанського населення вплинуло ряд причин, однією з яких є біженці з Албанії. Економічна ситуація в обох регіонах теж значно відрізняється і Сербія не $\epsilon$ членом таких організацій як НАТО та СС, в той час як ним є Королівство Іспанія.

Мадриду слід звернути увагу на ті помилки, яких він припустився у жовтні 2017 року під час проведення референдуму за незалежність. Це стосується саме поведінки поліцейських, дії яких були неправомірними стосовно тих громадян, які намагались висловити свою позицію на голосуванні. Адже, як ми бачимо, осуду з боку певних держав, або ж поважних осіб не оминути. I, головне, не оминути осуду з боку місцевого населення. Така поведінка руйнує імідж держави. А в добу інформаційних технологій це є досить негативним явищем.

Якщо акцентувати увагу на правильних діях Мадриду (з точки зору збереження цілісності держави), то доцільним буде сказати, що Королівство Іспанія приймало свої рішення досить зважено, що стосується подій після так званого референдуму. Головним результатом яких є збереження Каталонії у своєму складі та поступове врегулювання відносин між центром та автономією.

\section{Список використаних джерел та літератури:}

1. Resultats definitius. Generalitat de Catalunya. 2017.

2. The Catalan economy. Generalitat de Catalunya. 2016.

3. Ассанж закликав Юнкера призупинити членство Іспанії в Свросоюзі. Гордон. 2017. URL: http://gordonua.com/ukr/news/worldnews/-assanzhzaklikav-junkera-prizupiniti-chlenstvo-ispaniji-v-jevrosojuzi-209948.html 
4. Каталонія. Гордон. 2017. URL: http:/gordonua.com/tags/katalonija/ p11.html

5. Каталонія - багатий регіон Іспанії. Та чи зможе її економіка існувати самостійно. Еспресо. 2018. URL: https://espreso.tv/article/2017/10/04/ chy_vytrymaye_ekonomika_kataloniyi_rozluchennya_z_ispaniyeyu

6. Сепаратизм по-испански: какую цепную реакцию может запустить отделение Каталонии. Канал 24. 2017. URL: https://24tv.ua/ separatizm_po_ispanski_kakuyu_tsepnuyu_reaktsiyu_mozhet_zapustit otdelenie katalonii n864026

7. Catalonia election: full results. The Guardian. 2017. URL: https:// www.theguardian.com/world/ng-interactive/2017/dec/21/catalonia-electionfull-results

8. General Information. Barcelona Airport. 2015. URL: http://www. aeropuertobarcelona-elprat.com/ingl/aeropuerto_de_barcelona.htm

9. Rajoy assume la présidence de la Catalogne et convoque des élections le 21 décembre. Le Monde. URL: http://www.lemonde.fr/ europe/article/2017/10/28/rajoy-assume-la-presidence-de-la-catalogne-etconvoque-des-elections-le-21-decembre_5207264_3214.html

\section{Нікіма Беляєв, \\ студент 4 курсу}

Національний університет «Острозька академія»

\section{ІНІЦІАТИВА «ОАИН ПОЯС, ОАИН ШАЯХ » ЯК НОВІТНЯ ФОРМА ЕКОНОМІЧНОЇ ВЗАСМОАІї KHP TA EC}

На початку 2020 року ініціатива Китаю «Один пояс, один шлях» $\epsilon$ найважливішим інфраструктурним проєктом у світі. Вона має об'єднати приблизно 100 країн, в яких проживає 55\% світового населення та які формують $65 \%$ світового ВВП, в тому числі й Україну. Метою цього проєкту є поєднання Китаю із країнами Євросоюзу та Африки мережею транспортних магістралей, що будуть сприяти розвитку торгівлі.

3 початку XXI століття європейський ринок став ключовим напрямом для торгівлі Китаю, однак повноцінному розвитку цього виміру взаємовідносин перешкоджала відсутність якісних транспортних магістралей. Про запуск інфраструктурної ініціативи Китаю «Один пояс, один шлях», інша назва якої Новий шовковий шлях, було оголошено у два етапи. У ході державного візиту нового Глави КНР Сі Цзіньпіня до Казахстану у вересні 2013 було запропоноване співробітництво Китаю із державами Центральної Азії задля створення економічного поясу Шовкового шляху - сухопутної гілки проєкту. В ході візиту до Індонезії Глава Сі наголосив на важливості співпраці КНР та держав-членів АСЕАН для процвітання регіону й запропонував взаємодіяти разом задля реалізації нового морського транспортного коридору до Європи - морської гілки проєкту. В Джакарті ж він оголосив про створення Азійського банку інфраструктурних інвестицій, що передбачав фінансування реалізації обох частин проєкту.

Ініціатива «Один пояс, один шлях» фактично $є$ головним геополітичним інструментом Пекіна для поширення його впливу на міжнародній арені, перш за все на близькі до нього регіони Центральної та Південно-Східної Азії. Також сферою зацікавлення КНР в рамках цього проєкту є держави Африки, багаті на корисні копалини. 
Співпраця між Китаєм та Свропейським Союзом у рамках реалізації цього проєкту розвивається у двох напрямах: двосторонньому, між КНР та СС, та на рівні співпраці Китаю із кожною державоючленом окремо. Пріоритетним напрямом для керівництва Китаю $є$ розвиток саме міждержавних відносин. Така позиція КНР не влаштовує інституції ЄС та держави «великої трійки», адже це підриває внутрішню єдність Союзу та ставить під сумнів основоположні принципи об'єднання - солідарність та спільність.

Проявом такого підходу можна вважати створення у 2012 році Китаєм економічного форуму «Формат 16+1», який у 2019 році було розширено до 18 держав внаслідок приєднання Греції. Він об'єднує держави Центральної та Східної Свропи з одного боку та Китай 3 іншого. Членами цього форуму є такі держави-члени СС як Болгарія, Хорватія, Чеська республіка, Естонія, Угорщина, Литва, Латвія, Польща, Румунія, Словаччина, Словенія та Греція, тобто переважна більшість учасників. Під час першої зустрічі глав держав та урядів, що відбулася у рамках Формату у 2012 році у Варшаві було заявлено, що основна мета співпраці направлена на розширення взаємодії в економічній сфері, насамперед у торгівлі.

Жозе-Мануел Баррозу та лідери держав «великої трійки» під час Саміту Свропейської Ради в Брюселлі у 2012 році висловили глибоку стурбованість та занепокоєння активністю Китаю у Східній та Центральній Європі, що порушує внутрішню цілісність Євросоюзу. Активізація співпраці окремих держав $С С$ йшла у розріз із загальною парадигмою відносин Союзу із Китаєм, тому викликала різку критику серед провідних держав ЄС та очільників інституцій. Реакцією на значне посилення ролі КНР в Європі стало ухвалення 2016 році Європарламентом нового рамкового документа «Елементи нової стратегії Європейського Союзу до Китаю». Цей документ встановив нові, більш жорсткі правила для держав-членів СС щодо двосторонніх та багатосторонніх контактів із Китаєм. Було зазначено, що усі двосторонні угоди, які держави укладають з КНР, мають бути схвалені в Брюсселі, як ті «що сприяють загальному благу країн-членів Свропейського Союзу».

Загалом політику СС щодо цього проєкту у 2013-2017 роках можна характеризувати як доволі невизначену. Процес кристалізації позиції ЄС розпочався лише, тільки після обрання на посаду Президента Франції Еманюеля Макрона. Так, у своїй першій промові після обрання на посаду Е. Макрон заявив, що Європа потребує якісного партнерства з Китаєм та немає права втратити можливос- ті задля економічного зростання, які пропонує китайська ініціатива «Один пояс, один шлях».

У 2019 році відбулося європейське турне Сі Цзіньпіня, у ході якого він відвідав ряд країн Південної Європи: Італію, Іспанію, Португалію та Францію. У ході візит до Парижу відбулася зустріч з Еманюелем Макроном, на яку також були запрошені Ангела Меркель, Дональд Туск та Жан-Клод Юнкер. Ці переговори були значно складнішими для Глави КНР. Так, Сі був готовий до жорсткої позиції Макрона, який на саміті Свропейської Ради в Брюсселі в лютому 2019 року заявив, що «епоха європейської наївності до Китаю закінчилася, тепер настав час єдності».

Співпраця між Європейським Союзом та Китаєм у рамках ініціативи “Один пояс, один шлях" розвивається за характерним для акторів синусоїдним типом, тобто із почерговими періодами потепління та похолодання у відносинах. Проте взаємодія в рамках цього проєкту має ряд специфічних особливостей. Насамперед, це домінування ролі двосторонніх міждержавних відносин КНР із державами-членами Союзу. По-друге, Китай намагається мінімізувати вплив інституцій ЄС на реалізації проєкту. Проте, така політика, направлена на підрив внутрішньої єдності Європи, викликала серйозне занепокоєння провідних лідерів СС, насамперед Франції та Німеччини, що спонукало їх до пошуку оптимального варіанту розвитку взаємодії з Китаєм у цьому питанні. Фактично в СС за період від 2016 до 2020 року відбулася зміна бачення ролі Європи в ініціативі «Один пояс, один шлях» від несприйняття та критики, до активної співпраці, однак тільки за умови дотримання їхніх вимог.

\section{Список використаних джерел та літератури:}

1. 16+1' mechanism set to bolster China-Europe ties. Secretariat for Cooperation between China and Central and Eastern European Countries : веб-сайт. URL: http://www.china-ceec.org/eng/zdogjhz 1/t1575579.htm

2. Elements for a new EU strategy on China : Joint communication to the European Parliament and the Council від 22 червня 2016 p. URL: http:// eeas.europa.eu/archives/docs/china/docs/joint communication to the european_parliament_and_the_council_elements_for_a_new_eu_strategy_ on_china.pdf

3. Lily Kuo. What is China's Belt and Road Initiative? The Guardian. 2015. URL: https://www.theguardian.com/cities/ng-interactive/2018/jul/30/ what-china-belt-road-initiative-silk-road-explainer

4. Macron, Europe and the BRI. OBOReurope : веб-сайт. URL: https:// www.oboreurope.com/en/macron-europe-bri/ 
5. Philippe Le Corre. Europe's mixed views on China's One Belt, One Road initiative. The Brookings. 2017. URL: https://www.brookings.edu/ blog/order-from-chaos/2017/05/23/europes-mixed-views-on-chinas-onebelt-one-road-initiative/

6. Shobhit Seth. One Belt One Road. Investopedia. 2020. URL: https:// www.investopedia.com/terms/o/one-belt-one-road-obor.asp

7. What Does the Belt and Road Initiative Mean for Austria and the Region of Central East and Southeast Europe? Imfino : веб-сайт. URL: https://imfino.com/en/pages/news/what-does-the-belt-and-road-initiativebri-mean-for-austria-and-the-region-of-central-east-and-southeast-europecesee-part-2/

\section{Олександр Шама,}

дочент, кандидат історичних наук

Тернопільський начіональний педагогічний університет ім. В. Гнатюка

\section{ЗМІНА СУСПІЛЬНОГО СТАНОВИЩА ГААИЦЬКОЇ ШАЯХТИ У ХІХ - НА ПОЧАТКУ XX СТ.}

У широкій картині еволюції суспільних верств і груп у XIX - на поч. XX ст. безсумнівний інтерес викликає зміна становища шляхти - привілейованого військового стану старої Речі Посполитої. За деякими даними, в кінці XVIII ст. шляхтичів нараховувалось 1-1,3 млн. осіб, що становило 10-13\% загалу населення, яке тоді нараховувало близько 10 млн. (Д. Бовуа вважає, що з 8,8 млн. населення шляхти було 700-800 тис., тобто 10\% населення). Для порівняння: у країні «класичного феодалізму» - Франції з 20 млн. жителів тільки 140 тис. були дворянами (за іншими даними - 400 тис. 323 млн.; 100-120 тис., або 25 тис. сімей), тобто бл. 0,75\% населення. Отже, шляхетський стан у Речі Посполитій не був «тонкою вищою верствою як деінде», а складав «величезну, надзвичайно чисельну частину народу, настільки чисельну як у жодній іншій країні Європи». Зрозуміло, що далеко не всі представники військового стану були однаково багаті та упривілейовані - якраз навпаки, величезну його більшість становила незлічена маса шляхти дрібної, убогої, званої загоновою, ходачковою, сірячковою, частковою, чиншовою, околичною, застінковою (засцянковою), веретяною, капотовою, дрібною, дрібнопомісною тощо, що володіла заледве кількома моргами землі, яку власноручно обробляла або взагалі землі не мала, змушена працювати «за чинш» на великих і середніх землевласників i, таким чином, в економічному відношенні мало відрізнялась від «хлопів» (селянства). Наприклад, російський військовий і політичний діяч П. Зубов у записці Катерині II від 3.06.1796 р. зазначив, що чиншова шляхта, не володіючи власною нерухомістю, а будучи поневолена 3 давніх часів польськими вельможами, платила чинш і виконувала різні роботи та послуги за розпорядженням власників маєтків. Разом $з$ тим, у політичному, соціальному і культурному житті дрібна шляхта завдяки, серед іншого, своїй «згуртованій і чисельній масі»,

с Олександр Шама, 2020 
займала, за словами польського письменника В. Лозинського, «виняткове в суспільстві нашому становище». Згідно пізніших уявлень, шляхта у XVII-XVIII ст. вела «веселе, безтурботне, шалене i розгульне життя.., коли бенкети, весілля, з'їзди, судові процеси, поєдинки, свари, що часто вирішувались справжніми битвами, i, нарешті, міжусобна війна між різними політичними партіями» були іiі головним заняттям.

Із втратою незалежності Річчю Посполитою, а особливо після «селянської жакерії» 1846 р., коли «хлопи струсили 3 себе феодальні кайдани», і утвердження буржуазних відносин, «виняткове становище» більшості нащадків «польських рицарів» було зведене нанівець: у матеріальному, соціальному і культурному аспектах «хлопи» і «шляхта» остаточно злились у клас дрібних аграрних виробників (помічено, що синхронні джерела не вирізняють дрібну шляхту як окрему верству населення). В цих умовах, як зауважив $\mathrm{H}$. Дейвіс, «тільки чотири сотні родин могли слушно вважати себе за незалежних сільських шляхтичів», решта ж - приголомшлива більшість - була змушена братись до будь-якої роботи. Л. Сливка відмічає наступні, нетипові для шляхти заняття і професії: заготівля, сплавляння і перевезення лісу, млинарство, гуральництво, пасічництво, торгівля, ремесло (ткацтво, шевство, гончарство, кушнірство, чоботарство тощо); більше того, деякі найубогіші «шляхтичі» були змушені батрачити на «хлопів» - можливо навіть кріпаків їх предків. Тим не менше, такий «шляхтич» продовжував «з затятою впертістю» чіплятись за свій спосіб життя на селі, зрозуміло, не маючи до цього жодних реальних підстав. Звідси помітний суспільний інтерес до ходачкової (загродової) шляхти, викликаний, як влучно зауважила Г. Горинь, невідповідністю між іï «реальним станом найнижчої верстви сільської бідноти» $\mathrm{i}$ «манерою поведінки» родовитого панства.

\section{Список використаних джерел та літератури:}

1. Андерсон, Б. Воображаемые сообщества. Размышления об истоках и распространении национализма / Пер. с англ. В. Николаева; Вступ. ст. С. Баньковской. М.: «Канон-пресс-Ц», «Кучково поле», 2001. 288 с.

2. Бовуа Д. Гордиев узел Российской империи: Власть, шляхта и народ на Правобережной Украине (1793-1914) / Авториз. перев. с франц. М. Крисань. М.: Новое литерат. обозр., 2011. 1008 с.

3. Горинь, Г. Громадський побут сільського населення українських Карпат (XIX - 30-і роки XX ст.). К.: Наукова думка, 1993. 199 с.
4. Дейвіс Н. Боже ігрище: історія Польщі. Пер. з англ. П. Таращук. К.: «Основи», 2008. 1080 c.

5. Зашкільняк Л.О., Крикун М.Г. Історія Польщі: Від найдавніших часів до наших днів. Львів: Львів. нац. ун-т ім. І. Франка, 2002. 752 с.

6. История Франции в 3 томах. Отв. ред. А.З. Манфред Т.1. М.: «Наука», 1972. 357 с

7. Комар В.Л. Шляхта загродова. Енциклопедія історії України. T.10. Голова редк. В.А. Смолій. К.: «Наукова думка», 2013. С. 648. URL: http://www.history.org.ua/?termin=Shliakhta_zahrodova (дата звернення: 25.04.2020).

8. [Лось] И.Л. Качковский Сигизмунд. Энциклопедический словарь. T. XIV-а. Изд-ли Ф.А. Брокзауз (Лейпциг), И.А. Ефрон (С.-Петербург) Под ред. И.Е. Андреевского, К.К. Арсеньева, Ф.Ф. Петрушевского. С-Пб: Типо-литогр. И.А. Ефрона, 1895. С. 815.

9. Сливка Л.В. Галицька дрібна шляхта в Австро-Угорщині (17721914 рр.). Івано-Франківськ: Місто НВ, 2009. 220 с

10. Сливка Л. Джерела вивчення культури та побуту дрібної шляхти Галичини XIX - початку XX ст. Науковий часопис Національного педагогічного університету ім. М.П. Драгоманова. Серія 6: Історичні науки: зб. наук. праць. К.: Вид-во НПУ ім. М.П. Драгоманова, 2008. Вип. 6. C. 116-123. URL: http://www.enpuir.npu.edu.ua/ bitstream/123456789/16644/1/Slyvka.pdf (дата звернення: 24.04.2020).

11. Biegeleisen, H. Szlachta drobna w świetle poezyi ludowej. Warszawa: W-two Przeglądu Tygodn., 1887. 25 s.

12. Krasiński, A.S. Słownik synonimów polskich T.2. Kraków: Wyd. Akademii Umiejętności; w druk. «Czasu» F. Kluczyckiego, 1885. 477 s.

13. Łoziński, W. Szlachcic chodaczkowy. Powieść. Lwow: Nakł. K. Wilda, 1857. $249 \mathrm{~s}$.

14. Nowoczesna encyklopedia ilustrowana M. Arcta. Warszawa: Nakł. zakł. wyd. M. Arct. sp. akc. Odb. w druk. wł. Czerniakowa, 1937. [Cz. 2]. Szp. 961-1901.

15. Polska encyklopedja szlachecka. T.1 / Pod. red. S.J. StarykońKasprzyckiego. Warszawa: W-wo inst. kult. hist-nej, 1935. 374 s.

16. Ruppertowa, T. O szlachcie drobnej (inaczej czastkowej). Wisła. Miesięcznik geograficzno-etnograficzny. R. 1888. T. II, z. 4: Październik, Listopad, Grudzień. Warszawa: Skład gł. w księg. M. Arcta, 1888. s. 754-761. 


\section{Ігор Вознюк,}

\section{студент 4 курсу}

Начіональний університет «Острозька академія»

\section{ПРОБАЕМИ ВПРОВААЖЕННЯ ПЛАНУ АОНАЛЬАА ТРАМПА «МИР ЗАРААИ ПРОЦВІТАННЯ»}

Президент США Д. Трамп розкритикував посередницький підхід Б. Обами до вирішення ізраїльсько-палестинського конфлікту, і запропонував свій: команда експертів, на чолі з його зятем - Джаредом Кушнером - розробити мирний план «Мир заради процвітання: Бачення того, як можна поліпшити життя палестинців та ізраїльтян». Документ складається 3 двох частин: економічної та політичної, які були остаточно опубліковані та представлені на обговорення 28 січня 2020 року.

Попри те, що публікація мирного плану Дональдом Трампом відбулася порівняно недавно, все ж іiі дослідження присвячено досить широке коло публікацій, 3 огляду на актуальність таких наукових розвідок. Більшість 3 них характеризуються науковопубліцистичним характером. Вивчення умов плану та можливостей його застосуванням на практиці можна зустріти у дослідженнях I. Куси, В. Федяніна, К. Задираки. Серед іноземних дослідників варто виокремити роботи К. Свєтлової, Д. Мая, С. Фаяда, Д. Ігнатіуса, А. Варда, А. Шарая, Т. Варіка, К. Сетфорд. 3 огляду на активні зміни у ситуації з планом, варто і далі досліджувати дану проблему.

Розглядаючи генезу напрацювання та основні політичні та економічні умови мирного плану Д. Трампа «Мир заради процвітання», можна заявити, що план провалився в той момент, коли Адміністрація Білого Дому вирішила остаточно визнати Єрусалим столицею Ізраїлю та перенести туди своє посольство. Проте, навіть якби цього не сталося, сам план має певні умови та проблеми, які руйнують усі перспективи його втілення. Нижче перелічимо основні проблеми, що зробили неможливою реалізацію плану.

Першою проблемою угоди щодо мирного врегулювання можна вважати те, що вона явно $\epsilon$ неприйнятною та нереалістичною для палестинської сторони. План врегулювання, запропонований Куш- нером, по своїй суті розв'язує усі ключові питання (кордони, столиця, поселення, біженці) в одному напрямку - на користь Ізраїлю. Це сталося через те, що автори плану були зацікавленими та не могли діяти незаангажовано. Зрозуміло, що такі умови плану не сприйме жоден палестинський політичний лідер, оскільки це ознаменувало б його політичне самогубство і означало б, фактично, тотальну капітуляцію. А палестинський народ, який вже понад 70 років бореться з ДІ, ніколи на капітуляцію не згодиться.

Деякі дослідники, оцінюючи умови плану і такому вимірі заявлять, що він був «мертвонароджений». Також можна заявляти, що Дональд Трамп розробляв його радше заради якихось піар цілей, це можна пов' язати з датами випуску складових частин плану. Або ще можна розглядати варіант, що план із самого початку розроблявся таким, що палестинці його відкинули і відповідно можна було цим виправдовувати анексію Йорданської долини, яку активно обіцяе для своїх виборців Б. Нетаньяху.

Крім того, план ще можна схарактеризувати, як однобокий та безкомпромісний. Як вже писалося вище, що палестинцям пропонують відмовитися від усіх базових вимог, які були сенсом їхнього життя і боротьби проти, як вони вважають, «ізраїльських окупантів» протягом майже століття. В обмін на це палестинці повинні отримати гарантії на виплату 50 млрд. доларів протягом наступних 10 років. Зрозуміло, що тут немає жодного рівноцінного компромісу. I план має знак плюсу лише для Ізраїлю. На противагу, інша сторона конфлікту - палестинці - стають обмеженими та загнаними у глухий кут, що може в результаті призвести до радикалізації та до нової інтифади. Оскільки стіл переговорів перестає бути інструментом розв'язання проблем, а залишається лише зброя, як останній аргумент у конфлікті.

Ще іншою проблемою плану стало те, що він, насправді, не має мирного характеру. Дональд Трамп та автори угоди декларують, що це план мирного залагодження та врегулювання тривалого кровопролитного конфлікту, проте на папері ми маємо все навпаки. Так «Угода Століття» санкціонує анексію Ізраїлем чужої території. Мається на увазі Йорданська долина і частини палестинських земель на Західному березі річки Йордан, на яких розташовані ізраїльські поселення. Анексія, навіть схвалена однією з держав-лідерів у світі, сама по собі ніколи не веде до миру і не несе його. Навпаки, вона провокує війну, подальшу дестабілізацію та ескалацію конфлікту. Якщо розглядати ці концепції більш практично, то можна дійти висновку, що одностороння реалізація Ізраїлем цих положень, що зга-

(C) Ігор Вознюк, 2020 
дані вище, може наштовхнутись на войовничий спротив зі сторони місцевого арабського населення. А про це вже можна говорити, як про повноцінну основу для збройного конфлікту і нового повстання палестинців.

Отже, план Дональда Трампа щодо мирного врегулювання ізраїльсько-палестинського конфлікту провалився ще від самого свого початку. На це вплинув чинник активного розвитку Білим Домом відносин лише з однією стороною та повного ігнорування іншої Палестини. Також експертні кадри, які розробляли документ врегулювання були некомпетентними та не брали до уваги століття боротьби між народами, не намагалися розв'язати корінні проблеми, а намагалися за допомогою економічних чинників нав'язати мир для палестинців. Негативна реакція, яка надійшла після публікування плану з Рамалли та зі столиць арабських держав показала основні проблеми плану та основні причини неможливості його реалізації. Подальші дослідження у цій темі, а особливо зміни у прийнятті плану після виборів у Палестині є досить перспективними.

\section{Список використаних джерел та літератури:}

1. Дональд Трамп представил мирный план по израильско-палестинскому конфликту: что в нем особенного и почему об этом все говорят? URL: https://cutt.ly/BrOYbAz.

2. Чи приймуть Ізраїль і Палестина мирний план від Вашингтону? URL: https://dt.ua/international/ugoda-stolittya-imeni-trampa-337169_. html.

3. Should the Palestinians look a gift horse in the mouth? URL: https:// atlanticcouncil.org/blogs/menasource/should-the-palestinians-look-a-gifthorse-in-the-mouth/.

4. The two-state solution comes back. URL: https://www.atlanticcouncil. org/blogs/menasource/the-two-state-solution-comes-back/.

5. Trump's Middle East peace plan: What's there to be upset about? URL: https://www.brookings.edu/blog/order-from-chaos/2020/02/21/trumpsmiddle-east-peace-plan-whats-there-to-be-upset-about/.

6. Trump's peace plan and the Gulf Arab States' reaction. URL: https:// thehill.com/opinion/international/482737-trumps-peace-plan-and-the-gulfarab-states-reaction.

\section{Вікторія Гордійчук,}

студентка 4 курсу

Національний університет «Острозька академія»

\section{РОАЬ ТЕРИТОРІАЛЬНИХ СУПЕРЕЧОК У ВІАНОСИНАХ ЯПОНІЇ ТА ПІВАЕННОЇ КОРЁ̈}

Зважаючи на швидку трансформацію політичних та економічних відносин у регіоні Східної Азії, ключову роль тут починають відігравати взаємини між Японією та Республікою Кореєю. Зокрема, обидві країни після Другої світової війни обрали західний вектор розвитку інституту держави, що включає в себе демократизацію суспільства, ринкову модель економіки, розвиток соціальної бази, дотримання прав та забезпечення свобод людини. Ці суб'єкти міжнародних відносин є стратегічними союзниками Сполучених Штатів Америки у військовій та політичній сферах, також вони зацікавлені у вирішенні проблеми нуклеризації Корейського півострова та виступають близькими партнерами у питанні протидії економічній політиці КНР. Співробітництво між державами розвивається у сферах просування ідеї тісної співпраці на міжнародній арені у політичній та економічній сферах. Але дестабілізацію у взаємини між акторами вносить історична проблема територіального конфлікту за острови Ліанкур, острів Цусіма і протиріччя щодо назви Японського моря.

Розглядаючи проблематику відносин Японії та Республіки Кореї, було сформовано завдання до виконання:

1) дослідити причини конфлікту за острови Ліанкур та острів Цусіма. Визначити роль цього конфлікту у двосторонні відносинах;

2) окреслити позиції та аргументацію позицій обох сторін. Описати протікання конфлікту, загострити увагу на його активних фазах;

3) проаналізувати причини протиріччя довкола назви Японського моря, вказати його витоки, а також навести аргументацію, котрою послуговуються обидві сторони у обгрунтуванні власної позиції.

Метою дослідження $є$ аналіз впливу територіальних суперечок за острови Ліанкур та острів Цусіма, а також протиріч щодо назви Японського моря на відносини Японії та Республіки Кореї.

(C) Вікторія Гордійчук, 2020 
Варто зауважити, що коло доступних матеріалів для опрацювання $\epsilon$ досить обмеженим та не включає в себе праці вітчизняних науковців. У своїх дослідженнях авторка статті користувалася здебільшого інтернет джерелами, офіційними сайтам МЗС Республіки Кореї та Японії й статтями у вітчизняних та закордонних періодичних виданнях. Важливий внесок до напрацювання науково-дослідної бази відносин Японії та Південної Кореї було зроблено Б. Глоссерманом, С. А. Снайдером, та Тхе Хе Кімом, котрі працювали над дослідженням відносин Японії та Південної Кореї, а також проаналізували вплив США на двосторонні відносини. Проблематика історичного контексту відносин Японії та Республіки Кореї розробляється К. Кімурою.

За останнє десятиліття суттєво зросла напруга довкола територіальної суперечки за острови Ліанкур. Це сталося на фоні охолодження відносин між Японією та Південною Кореєю, котре було спричинене несумісними поглядами на спільне минуле, зокрема його трактування. Свою роль у погіршенні відносин зіграла також торгова війна, яка розпочалася на фоні цих непорозумінь. Перш ніж розглядати вплив суперечки на відносини, варто визначити та дати пояснення самого об'єкту суперечки. Острови Ліанкур - це група незаселених скелястих островів, котрі розташовані в Японському морі та підконтрольні Республіці Кореї. Тривалий час велася дискусія щодо їх приналежності, хоча офіційно Японія претензії на цю територію не оголошувала. Варто зазначити, що острови окрім загально прийнятої назви, Ліанкур.

Інтерес Японії та Республіки Кореї до цих островів у більшій мірі стосується не браку територій висловлення протесту іншій стороні, а також підкреслення непорушності кордонів та сили держави на міжнародній арені. Для Південної Кореї ця суперечка є своєрідною можливістю утвердження власних позицій у регіоні. В свою чергу, для Японії перемога Республіки Кореї означатиме втрату впливу у регіоні та буде виявом слабкості, що є неприпустимим для політичних еліт. Окрім геополітичних чинників, інтерес до островів Японії та Південної Кореї стосується також прибережних вод та шельфу. Акваторії довкола островів багаті рибою та водоростями, а також потенційно містять поклади природного газу та, як наслідок, - метанового клатрату.

Події довкола островів розвивалися досить не рівномірно. Періодично дискусії щодо островів затихали, проте ні для Японії, ні для Південної Кореї ця суперечка не втрачала своєї актуальності. Через це відносини Південної Кореї та Японії часто загострювалися, на- приклад у 2008 р. Міністерство освіти та науки Японії затвердило коментар до методичного посібника для вчителів, у якому вперше рекомендувало звертати увагу учнів на територіальну суперечку між Японією та Республікою Кореєю. У відповідь на це Південна Корея виразила протест і вимагала прибрати ці рядки з методичного посібника, на що Японія відповіла різкою відмовою. Як результат, Південна Корея відкликала свого посла з Японії. Згодом ця ситуація дещо втихла, а посол Республіки Кореї повернувся до Японії. В наступні роки напруга довкола островів лише посилилася. Зважаючи на все більше загострення суперечки, японська сторона звернулася до уряду Республіки Корея із пропозицією подати спільний позов до Міжнародного суду для остаточного врегулювання існуючої проблеми. Проте, Південна Корея відмовилася і звинуватила Японію в підігріванні конфлікту. У «Білій книзі з питань оборони» від 2017 р., Японія декларує, що острови Такесіма є споконвічною власністю японського народу і державний уряд не має наміру відмовлятися від претензій на них.

Територіальний конфлікт, створює певне напруження для обох держав, стосується також острова Цусіма, котрий входить до складу Японії. Офіційно Сеул так і не оголосив свої претензії на цю територію, проте громадяни Республіки Кореї часто вимагають від уряду встановити контроль над островом та включити його до складу Південної Кореї. Це створює напруження не лише на рівні сприйняття націй та їх ставлення один до одного. Протиріччя має негативний вплив на формування добросусідських відносин, i, як результат, підігріває вже існуючі суперечки та конфлікти.

Ще одне протиріччя стосується назви моря, котре розташоване між Корейським півостровом та Японським архіпелагом, починаючи 31992 р. на кожній конференції ООН, що стосується уніфікації географічних назв, Південна Корея висуває пропозицію переглянути назву Японського моря і замінити іiі на «Східне море» чи «Східно-корейське море», або затвердити можливість використання обох назв, як Японського моря так і Східного моря.

Найбільш поширеною та загальноприйнятою його назвою $є$ «Японське море». Вона була прийнята на конференції Міжнародної гідрографічної організації, котра стосувалася меж морів та океанів і була проведена під егідою ООН. Сьогодні більше 97 \% карт, якими користуються у всьому світі, за винятком карт у Республіці Кореї та Північній Кореї, використовують саме цю назву. 


\section{Список використаних джерел та літератури:}

1. B. Glosserman S. A. Snyder. The Japan-South Korea Identity Clash: East Asian Security and the United States. New York City: Columbia University Press, 2017. 240 p.

2. J. James Kim, Kang Chungku. South Korean Attitudes about ROKJapan Relations on the Rocks. URL: http://en.asaninst.org/contents/southkorean-attitudes-about-rok-japan-relations-on-the-rocks/\#1

3. Kan Kimura. The Burden of the Past: Problems of Historical Perception in Japan-Korea Relations. Michigan: University of Michigan Press, 2019. p.

4. Андрей Сафронов. Quote.rbc.ru. Почему разругались Япония и Южная Корея 2019. URL: https:/quote.rbc.ru/news/article/5d234b7f9a79 $478 \mathrm{e} 89 \mathrm{a} 122 \mathrm{ad}$

5. Посольство Японії в Україні. Питання «Такешіма» URL: https:// www.ua.emb-japan.go.jp/itprtop_uk/00_000844.html\#\%D0\%A2\%D0\%B0 $\%$ D0\%BA $\%$ D0\%B5\%D1\%88\%D1\%96\%D0\%BC\%D0\%B0:\%20\%D0\%93 $\% \mathrm{D} 0 \% \mathrm{BE} \% \mathrm{D} 0 \% \mathrm{BB} \% \mathrm{D} 0 \% \mathrm{BE} \% \mathrm{D} 0 \% \mathrm{~B} 2 \% \mathrm{D} 0 \% \mathrm{BD} \% \mathrm{D} 0 \% \mathrm{~B} 0$

6. Ministry of Foreign Affairs of Japan. The Issue of Name "Sea of Japan". 2017. URL: https://www.mofa.go.jp/a_o/na/page1we_000109.html

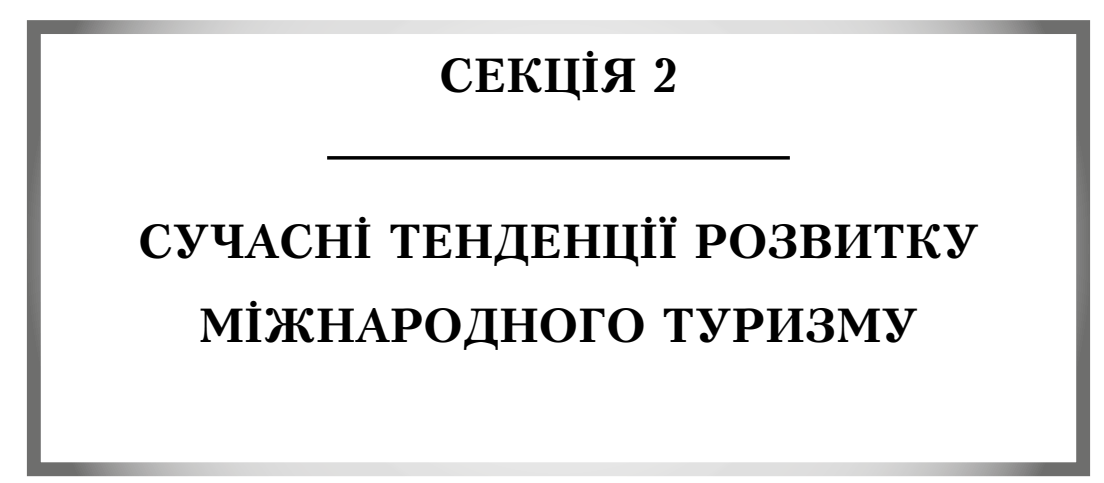




\section{Анастасія Машенцова,}

студентка 4 курсу

Національний університет «Острозька академія»

\section{РОЗВИТОК ТУРИЗМУ АЯЯ РІЗНИХ СОЦІААЬНИХ ГРУП У ПОРТУГААІЇ}

За рейтингом Всесвітньої організації туризму (UNWTO) 2019 року, який укладається на основі міжнародних туристичних відвідувань, Португалія входить у 20-ку найбільш відвідуваних країн світу. За даними UNWTO кількість туристів, які прибули до країни 2019 року, становить 22,8 млн осіб. Радою з туризму Португалії (Turismo de Portugal) передбачалося, що у 2020 році туристів буде значно більше. Але 3 ситуацією, яка склалася на сьогодні у світі, поширення COVID-19 значно погіршились прогнози міжнародних туристичних відвідувань.

Оскільки Португалія є досить відвідуваною країною, то її туристи - це люди різних соціальних груп, наприклад: молодь, сім'ї з дітьми, туристи похилого віку, а також інклюзивні. Усі вони різні між собою, але в країні досить розвинута туристична інфраструктура, яка забезпечує їх максимально комфортним та пізнавальним відпочинком, а саме: якщо молодь віддає перевагу розважальному туризму, нічним розвагам, то сім'ї з дітьми - пізнавальним екскурсіям, пляжному відпочинку. Відпочивальники пенсійного віку та інклюзивні туристи найчастіше надають перевагу спокійному, пізнавальному відпочинку, гастрономічним турам. Після вищезгаданого виникає питання: так чим же особливий туризм Португалії для різних соціальних груп?

Відомо, що молодь $є$ найбільш активною соціальною групою серед населення. Вони обирають різноманітні види відпочинку. Це можуть бути тури вихідного дня, оглядові чи тематичні екскурсії, фестивалі, концерти, а також часто молодь обирає й екстремальний відпочинок, який створює для відпочивальників неповторну атмосферу тощо [1].

Фестивалі - це те, чому молоді туристи надають перевагу. Найбільше їх проходить улітку, а саме в період липень - серпень. Оскільки у Португалії люблять святкування, то фестивалів є чимало

(C) Анастасія Мамениова, 2020 і вони всі різняться між собою тематикою, тривалістю, змістом і навіть формою.

Досить очікуваною подією як серед туристів, так і серед місцевого населення $є$ Винний фестиваль на Мадейрі (Madeira Wine Festival / Festa do Vinho da Madeira), який проходить вкінці серпня - на початку вересня. Це цікаві шоу, фольклорні танці та багато іншого на честь відомого всьому світу напою - подія, яка безперервно триває цілий тиждень. Саме свято пов'язане з часом традиційного збору винограду і виготовлення вина. Також подією особливого масштабу вважають Кінофестиваль, який проходить кожного року навесні. Тут туристів чекає різноманітна програма, яка поєднує в собі кіноперегляди, концерти, лекції, семінари та творчі зустрічі з авторами фільмів [2;3].

Щодо концертів, то відомою подією в країні є концерт «NOS Alive», який проходить в Лісабоні щороку влітку. Також його відносять до популярних європейських фестивалів інді, рок та альтернативної музики. Для усіх відвідувачів, особливо це є вигідним для туристів, курсують безкоштовні автобуси між торговим центром Alegro Alfragide та місцем проведення NOS Alive [4].

Туризм для молоді в Португалії також передбачає ще нічний відпочинок. Любителі активного нічного відпочинку надають перевагу численним танцмайданчикам клубів та дискотек, де часто професіонали вчать аматорів новим па, а то і комбінаціям рухів у латиноамериканській програмі (самба, ча-ча-ча тощо). Наприклад, у місті Кайшкайш для молодих туристів представлений широкий вибір барів, парків атракціонів, а також ресторанах з живою джазовою музикою. Більшість розважальних закладів розташовано на узбережжі, поблизу готелів. Туристи приїжджають у місто Монті-Ешторіл, відвідавши нічний клуб «Bauhaus», знайомляться 3 місцевими музичними гуртами. Молодь в Лісабоні щовечора знаходиться на вулицях Старого міста, адже там $є$ велика кількість барів та клубів, що розташовані в області Россіо (центр міста) і на Авеніда да Лібердаді. Також в інших кварталах туристи відпочивають у караоке-барах, танцювальних клубах чи просто мають можливість послухати улюблені музичні твори у виконанні місцевих гуртів [5].

Щодо сімейного туризму, то він у Португалії $\epsilon$ звичним явищем, оскільки щороку тисячі сімей приїжджають сюди у відпустку. Сімейний відпочинок з дітьми в Португалії обирають переважно тому, що на території країни є велика кількість пляжів і всіляких розваг, а сприятливий клімат і навколишня екологія дає можливість оздоровитися як дітям, так і дорослим. 
Для туристів, які вперше відпочивають у Португалії з дітьми, є декілька особливостей, які варто пам'ятати:

- спершу слід дізнатися про умови, які пропонуються для туристів 3 дітьми. У деяких готелях Португалії є послуги няні, заняття в дитячому клубі або безкоштовні екскурсії для дітей;

- в країні є досить велика кількість кафе, але варто пам'ятати, що всі кафе в Португалії починають працювати з 19.30 вечора;

- у всіх супермаркетах і аптеках країни туристи мають можливість знайти широкий асортимент дитячого харчування, оскільки воно тут має великий попит [6].

Сімейний туризм в Португалії - це часто поєднання пляжного відпочинку з численними відвідуваннями різноманітних національних парків, парків розваг, прогулянках на яхті, а також ознайомлення із культурно-історичною спадщиною країни.

У країні пропонується широкий спектр розваг для дітей будьякого віку, що приваблює сім’ї з дітьми різного віку. Оскільки держава дбає про потреби молодшого покоління, створюючи їм всі умови для комфортного перебування і розвитку, туристи під час відпочинку з дітьми надають перевагу відвідуванням океанаріума, зоопарку або беруть участь в катанні на яхті, а також відвідують відомий парк розваг «Кідзанія». Він знаходиться в столиці країни Лісабоні. Щодня парк розваг приймає тисячі відвідувачів, оскільки не тільки туристи надають йому перевагу під час відпочинку, а й місцеве населення. Адміністрація парку розваг створює усі сприятливі умови для безпечного та корисного відпочинку дітей [7].

Наприклад, під час сімейної подорожі туристи надають перевагу аквапарку «Vila Real», оскільки єдиний простір розділяється на ділянки: безпосередньо аквапарк, місце для дітей, зона навчання кемпінг. Також в Лісабоні популярними місцями для туристів 3 дітьми є зоопарк та океанаріум [5].

Португалія стала першою країною, що отримала звання «туристичний напрямок, що доступний для всіх» від Всесвітньої туристичної організації. Нагорода, вперше вручена у 2019 році UNWTO спільно з Фондом ONCE (Іспанська національна організація незрячих), свідчить про визнання заслуг Португалії в розвитку туризму доступного для людей різного віку, достатку чи потреб. У Європі близько 90 мільйонів потенційних покупців послуг інклюзивного туризму, тому нагорода є важливою подією для Португалії.

Спеціально для тих, хто потребує особливої підтримки й має труднощі пересування, в країні є підготовлені тури (маршрути) по 20 містах $з$ розміткою особливими знаками, що вказують, що ці маршрути підходять для осіб з обмеженою рухливістю. Для осіб 3 обмеженими фізичними можливостями $є$ також переваги й в трансфері. Наприклад, в аеропортах Португалії при необхідності пасажири можуть також скористатися послугою MyWay - це персоналізований сервіс для осіб з обмеженою рухливістю. У Португалії у всіх великих містах існують автомобілі таксі, спеціально адаптовані для осіб з обмеженою рухливістю. Окрім трансферу в Португалії, влада країни також створює комфортні умови для відпочинку на пляжах У Португалії нараховується 215 різних пляжів, морських і річкових 3 доступом для осіб з обмеженою рухливістю. Ці пляжі відзначені спеціальним знаком - білим прапором з символом «Пляж зі зручним доступом» жовто-блакитного кольору [8].

Уряд за планом працює над перетворенням Португалії в країну, доступну для всіх. Ще у 2016 році була запущена програма «Все для всіх», метою якої стало розширення можливостей туристичного сектора, поширення інформації про готелі, транспорті, пляжах зі зручностями для людей з обмеженою мобільністю, допомога в створенні спеціальних маршрутів від Півночі до Півдня Португалії [9].

Туризм для різних соціальних груп - це багатогранний та різний за своєю функціональною структурою процес. Оскільки перелічені види туризму в Португалії відрізняються як за своєю організацією так і за видами діяльності. Влада країни намагається раціонально розділяти фінансування для кожного згаданого виду туризму, а також удосконалювати й розвивати їх у майбутньому.

Ситуація, яка склалася на сьогодні у світі через COVID-19, спричинила певні труднощі у розвитку туризму Португалії. Але Рада 3 туризму Алгарве разом з Радою з туризму Португалії працює над відновленням туристичної галузі. Вони стверджують, що доведеться поміняти принципи роботи компаніям з прокату автомобілів, аквапаркам і туристичним розважальним підприємствам. Також після запланованого скасування 3 травня 2020 року надзвичайного стану власники полів для гольфу, пляжів, готелів, ресторанів, барів, пристаней для яхт і рекреаційних портів отримають нові рекомендації, щодо наступних дій, щоб гарантувати безпеку та відновлення туристичної галузі.

\section{Список використаних джерел та літератури:}

1. Туризм для молодежи. URL:

2. https://www.visitportugal.com/ru/experiencias/jovem

3. Винные и гастрономические фестивали в Португалии. URL: http:// mastertura.com.ua/article/viewarticle/42/1509/ 
4. Madeira Film Festival. URL: http://madeirafilmfestival.com

5. Nos Alive. URL: https://nosalive.com

6. Активный отдых и развлечения в Португалии - как интересно провести время. URL: http://www.orangesmile.com/destinations/portugal/ attractions.htm

7. Семейный отдых с детьми в Португалии - куда съездить. URL: http://www.orangesmile.com/destinations/portugal/familychildren.htm

8. Семейный отдых в Португалии. URL: https://tripmydream.com/ portugalia/familytrip

9. Туризм для лиц с ограниченной подвижностью. URL: https://www. visitportugal.com/ru/experiencias/turismoacessivel?field_nome_sugestao_ value

10. Tourism for all. URL: https://www.tur4all.pt

\section{Анастасія Морозецька,}

студентка 4 курсу

Начіональний університет «Острозька академія»

\section{ГАСТРОНОМІЧНИЙ ТА ВИННИЙ ТУРИЗМ В ITA^IÏ У XXI CTOАITTI}

Гастрономічний туризм в останні роки набуває все більшого розвитку та стає повноправним гравцем на міжнародному туристичному ринку. Якщо ще у 2000-х роках цей процес не був туристичною діяльністю, яка приносить кошти, то починаючи з 2012 року та до сьогодні гастрономічний та винний туризм набуває все більшої популярності. У багатьох країнах гастрономічний та винний туризм уже стали одними із провідних галузей у сфері туризму, цьому сприяє розвиток мережі зв'язків на місцевому та регіональному рівнях економіки. Особливо популярними регіоном гастрономічного та винного туризму вважається Європа, а однією із тих країн, яка вже давно визнана як приваблива для туристів, які бажають пізнати національну кухню, $є$ Італія, яка займає 3 місце серед гастрономічних центрів Свропи та має світову репутацію у сфері кулінарії завдяки численним сертифікатам $Є$ С шодо якості продукції та напоїв. За статистикою, щороку країну відвідує близько 60 млн туристів, з яких 8 \% прибувають 3 метою участі у гастрономічних та винних турах та загалом цікавляться гастрономією.

Позитивний розвиток гастрономічного туризму зумовила унікальна національна кухня Італії, одна із найбільш поширених у світі. Історично склалось так, що північні регіони славляться своїми м'ясними та молочними стравами, адже тут надзвичайно розвинуте скотарство, а ось Південь Італії популярний своїми вегетаріанськими стравами та морепродуктами, оскільки ці регіони були біднішими. Здобули світову славу і стали інтернаціональними стравами піца, спагеті, равіолі, ризотто, лазанья, карпачо та тірамісу. 3а даними італійського звіту із гастрономічного та винного туризму 2019 року, Італія пропонує близько 825 продуктів, характерних для певного регіону та 5056 традищійних продуктів харчування. У країні розташовано майже 335 тисяч закладів харчування, близько 23 тисячі ферм та 114 тематичних музеӥв, які пов'язані із темою га-

(C) Анастасія Морозецька, 2020 
строномії, а також в Італії розташовано 173 «винні дороги» та 3900 виноробень. Позитивним фактором для розвитку гастрономічного та винного туризму у країні також $є$ політика уряду Італії. Зокрема, Національне Агентство з туризму в Італії підтримує гастрономічний туризм через програму «Готуємо з Італією», Міністерство внутрішньої торгівлі країни просуває усі італійські товари зі знаком «Made in Italy» на міжнародному ринку, а Інститут кухні, культури та енології Італії займається популяризацією традицій італійської кухні та культури за кордоном шляхом проведення лекцій, майстеркласів та уроків.

Як правило, гастрономічні тури є доповненням до головної цілі візиту у країну. Поширені гастрономічні тури всією країною. Найбільш популярний регіон гастрономічного туризму - це Тоскана Однак, чималий інтерес викликають регіони Ломбардія, Лаціо, Фріулі-Венеція-Джулія, П'ємонт. Найпоширенішими видами гастрономічного туризму на сучасному етапі $є$ дегустація місцево кухні регіону, відвідування продуктового ринку та ознайомлення із традиційними продуктами регіону, тури ресторанами та кафе, та різноманітні винні тури. Також, популярністю серед туристів користуються різного роду ярмарки, виставки продуктів, свята та дні їжі, відвідування фабрик із виробництва продуктів, також деякі регіони пропонують навчання у кулінарних школах та відвідування майстер-класів. Популярністю серед туристів користуються різноманітні ярмарки, виставки та свята їжі. Серед них: флорентійська ярмарка Pitti Taste у Флоренції (Тоскана), фестиваль шоколаду Eurococolate в Перуджі (Умбрія), ярмарок білого трюфеля Tarufo Bianco d'Alba в Альбі (П'ємонт), свято піци у Неаполі (Кампанія) та міланський тиждень їжі Milano Food Week (Марке). Щорічний осінній ярмарок білого трюфеля у місті Альба (П'ємонт) у 2019 році (89 ярмарок) зібрав близько 600 тисяч відвідувачів, 70\% 3 яких іноземці, переважно 3 країн Свропи (Швейцарія, Німеччина, Франція, Великобританія), а також збільшилось число туристів із США, Бразилії та Австралії. У 2018 році країну відвідало близько 120 тисяч туристів, які приїхали з метою полювання на трюфелі. Загалом, аналітики, оцінюючи цю галузь туризму країни, наголошують на тому, що зараз цей вид туризму оцінюється для Італії у близько 63 млн євро. Також, вони вважають, що протягом наступних 20 років, річний обсяг торгівлі трюфелями збільшиться та досягне 5,2 млрд євро. Досить поширеною розвагою серед туристів є також відвідування музеїв їжі. Зокрема, музей шинки у 2019 році прийняв найбільше відвідувачів серед музеїв Парми - 5457 туристів, а музей салямі - 5424 відвідувачів.
Музей пармезану має 234 тисячі відвідувачів щороку, а музей шоколаду вражає кількістю відвідувачів - 66 тисяч щороку.

Щодо винного туризму, то більш як 50 \% гастрономічних турів в Італію складають дегустаційні тури, які розташовані на 173-х «винних дорогах». Найпопулярнішими регіонами винного туризму вважаються П'ємонт та Тоскана, які відомі своїми переважно червоними винами: Неббіоло, Барбера, Дольчетто, однак популярні серед туристів також Ломбардія, де основними сортами винограду є Корвіна, Шардоне та Мерло, з яких виробляють червоні та білі вина, серед південних регіонів - Сицилія, де виробляють вино із таких сортів винограду як Фіано, Нурагус, Мальвазія та Греко. Кожна провінція змагається за пріоритет у мистецтві виноробства, крім того, вважається, що вина північних провінцій більш ніжні, ніж вина півдня (за винятком Сицилії). Подібно гастрономічним турам, самостійні винні тури передбачають відвідування місць, де виробляють вино, дегустація вин, проживання у винних дворах та можливість взяти участь у заходах, пов'язаних із виробництвом вина. Надзвичайно популярним $є$ регіон Сицилії, що пов'язано із близькістю до вулкана Етна. У період з 2013 по 2016 роки туристичний потік склав близько 150 тисяч, у період з 2011 по 2013 роки він становив 83 тисячі. Завдяки збільшенню туристів збільшується і виробництво вина, зокрема вино Spumante Etna Bianco у період з 2012 по 2018 рік збільшилось із 4 тисяч пляшок до 84 тисяч. Щодо фестивалів пов'язаних із вином, то популярними є фестиваль вина Fiera del Vino у Монтеф'ясконе (неподалік Риму, Лаціо), виставка вин Vinitaly у Вероні (Венето), фестиваль вин К'янті у Флоренції (Тоскана). Зокрема, у 2019 році виставка вин у Вероні зібрала близько 125 тисяч відвідувачів зі 145 країн світу (найбільше з США, ФРН, Великобританії, Китаю та Канади). Важливим є те, що ця виставка популяризує італійського виробника та продукцію за кордоном. У 2016 році виставка пройшла у Бразилії, а з 2020 року запущено платформу «Wine to Asia», перша виставка відбудеться у Шеньчжені (Китай) у 2020 році. Музеїв вина налічується досить багато, до прикладу у П'ємонті - музей вин Мартіні у Пессіоне, в Умбрії музей вин Lungarotti у Перуджі, у Марке - музей винних етикеток у Мілані.

Однак, попри досить велику кількість іноземних туристів, Італія все ще поступається своїм сусідам - Франції та Іспанії. Гастрономічний та винний туризм в Італії, як і інші види туризму, більш розвинені на півночі аніж на півдні, що пояснюється віддаленістю південних областей країни. Попри популярність еногастрономіч- 
ного туризму, досить мало інформації щодо гастрономічних та винних маршрутів країною. До прикладу, 24 \% «винних доріг» мають власний вебсайт з інформацією про маршрут для смартфонів, однак інша частина досі цього немає. Проте, беззаперечним $є$ той факт, що роль гастрономічного та винного туризму у країні з роками лише посилюється. Зокрема, активна участь країни у різноманітних форумах лише сприяє розвитку гастрономічного туризму. До прикладу, завдяки участі Італії у проєкті MEDFEST вдалось покращити ярмарку грибів, яка проходить у Сполето (Умбрія). Найголовніша ініціатива - залучення малих підприємців та місцевих туроператорів для покращення якості заходу та створення нових гастрономічних маршрутів місцевістю. Також, важливою ініціативою уряду було створення нових або ж використання історичних будівель для поширення туризму. У Звіті щодо гастрономічного та винного туризму в Італії 2019 року представниця винних заводів Florio Capa Монтальбано зазначила, що завдяки виділеним компанією коштам, було побудовано дегустаційну кімнату та відкрито панорамну терасу. Завдяки цьому, кількість туристів до заводів компанії складає близько 50 тисяч щороку. Тому попри проблеми, перспективи все ж переважають, адже уряд зацікавлений у покращенні та популяризації не лише цього виду туризму, а й бренду «Made in Italy». Для цього, було створено спеціальну фірму, яка спеціалізується на організації винного туризму - «Gourmet Getaways» та гастрономічного $-\ll$ Eating Italy».

\section{Список використаних джерел та літератури:}

1. Alba, olte 600000 visitatori alla Fiera internazionale del Tartufi bianco. URL: $\quad$ https://www.terraetradizione.com/2018/11/27/alba-oltre-600-000visitatori-alla-fiera-internazionale-del-tartufo-bianco/.

2. CBI What is the demand for outbound tourism on the European market? URL: https://www.cbi.eu/market-information/tourism/trade-statistics/

3. Deutsche Welle Italy attracts visitors with food and wine. URL: https:// www.dw.com/en/italy-attracts-visitors-with-food-and-wine/a-41374779.

4. East Lombardy Application. A taste of Italy. European region of Gastronomy 2017. URL: https://europeanregionofgastronomy.org/wpcontent/uploads/2016/12/6.East-Lombardy.pdf.

5. Eurochocolate, a Perugia il festival del cioccolato. URL: https:// www.ilturista.info/blog/12464-Eurochocolate_a_Perugia_il_festival_del_ cioccolato/.

6. Fiera Intarnazionale Tartufi Bianco D'Alba. URL: https://www. fieradeltartufo.org/.
7. Find Your Italy The rising opportunity of wine tourism in Italy. URL: https://www.findyouritaly.com/rising-opportunity-wine-tourism-italy/.

8. First report on Italian food and wine tourism. URL: https://www. robertagaribaldi.it/first-report-food-and-wine-tourism/?lang=en.

9. Focus Sicilia I numeri di ViniMilo 39. URL: https://www.focusicilia. it/2019/09/11/vinimilo-numeri-evento-enogastronomia-etna/.

10. IGCAT Report on Food Tourism in Italy: gastronomy as key factor in the decision-making process. URL: https://igcat.org/report-food-tourismitaly-gastronomy-key-factor-decision-making-process/.

11. Italia Convention Report on Italian food and wine tourism, 2019. URL: https://www.italiaconvention.it/en/news-en/food-and-wine-report-2019/.

12. ITALIA: Agenzia Nazionale Turismo. Gastronomy. Italy, Territory of taste. URL: http://www.italia.it/en/travel-ideas/gastronomy.html.

13. La casa del cioccolato esiste ed è a Perugia. URL: http://familylife. tgcom24.it/2015/11/30/la-casa-del-cioccolato/.

14. MED Culinary heritage experiences: how to create sustainable tourist destinations. URL: https://medfest.interreg-med.eu/it/.

15. Officine Turistiche Why is food and wine tourism important in Italy? URL: http://www.officineturistiche.it/en/perche-turismo-enogastronomicoimportante-per-l-italia/.

16. Record di visite per i Musei del Cibo. Prosciutto di Parma superstar. URL: https://www.informacibo.it/record-visitatori-musei-del-cibo-2019/.

17. Statista. URL: https://www.statista.com/.

18. The Local it "Truffle tourism" worth 63 million euros in Italy. URL: https://www.thelocal.it/20181123/truffle-tourism-worth-63-million-eurosin-italy.

19. Tourism Review Italian gastro-tourism registers growth. URL: https:// www.tourism-review.com/gastro-tourism-in-italy-still-very-attractivenews 10928

20. Truffle hunting and truffle eating in Italy. URL: https://www. beerandcroissants.com/truffle-hunting-in-italy/.

21. Vinitaly Lungarotti, 50 VinItaly tra vino, cultura e ospitalità. URL: https://www.vinitaly.com/it/verona/news/parola-alle-aziende/lungarotti-50vinitaly-tra-vino-cultura/.

22. Vinitaly. URL: https://www.vinitaly.com/

23. Visàvin Musei del vino in Italia. URL: http://www.visavin. it/2019/02/07/turismo-enologico-musei-del-vino-in-italia-da-visitare/.

24. Winery Tasting Sicily Contrade Dell'Etna in Sicilia 2019. URL: https://www.winerytastingsicily.com/blog/events/contrade-dell-etna-2019april-14-15-at-the-castello-romeo/.

25. Wining. Un portale di ottima annata. URL: http://www.wining.it/ vinitaly-ledizione-numero-53-chiude-125-mila-visitatori-33-mila-buyer/.

26. Гастрономические и винные туры в Италию. URL: https 
27. Гастрономические туры в Италию. URL: https:/www.svoiludi.ru/ italy/gastronomic-tours.html.

28. Gastronomic cities: City strategy on gastronomy as a tool for tourism ad employment development. Baseline Study. Published by EU, 2014. P. 16.

29. Global Report on Food Tourism. AM Reports: Volume four. Published

by UNWTO, Madrid, 2015. P. 8-9.

30. Key trends in culinary tourism. Published by GlobalData, 2018. P. 8, 20.

31. MEDFEST. Gastronomy and Tourism Success Stories in the Mediterranean. Published by Troodos Network of Thematic Centres, Platres, 2019. P. 19-20.

32. Roberta Garibaldi Food, Art and Tourism as a boost for innovation: successful experience from Italy. University of Berhamo. Published by IGCAT, 2016. P. 1-4.

33. Second Global Report on Gastronomy Tourism. Affiliate Members Report: Volume sixteen. Published by UNWTO, Madrid, 2017. P. 152.

\section{Анна Беленкова,}

студентка 4 курсу

Національний університет «Острозька академія»

\section{ТУРИСТИЧНА ІНАУСТРІЯ КОРЕЙСЬКОЇ РЕСПУБАІКИ}

Республіка Корея - країна у Східній Азії. Знаходиться у південній частині Корейського півострова. Корейський півострів, розташований в Північно-Східній Азії, омивається з 3-х сторін морем. На сході - Японським морем, на заході - Жовтим, на півдні - СхідноКитайським морем. Межує з Японією, КНР і Північною Кореєю. Згідно з даними за 2020 р., населення країни складає 51,4 млн осіб.

Останні десятиліття країна активно розвиває власну сферу туризму і вже сьогодні можна спостерігати значні успіхи. Щороку, популярність країни як туристичної дестинації росте. Можна виділити праці багатьох дослідників в галузі культурології, економіки та маркетингу, зокрема Лазарєва К. В., Новікова Є.Ю та Хан Джи-хи, які підіймають питання стану та розвитку туристичної індустрії в Південній Кореї.

Ця країна - центр економічної, культурної та творчої діяльності в Азії. Корея була колонізована Японією на початку XX-го століття, а пізніше їй довелося пережити Корейську війну (1950 - 1953 рр.), але вона домоглася разючого економічного зростання за короткий період відомого як «Диво на річці Хан».

Країна славиться своєю унікальною та довгою історією, що бере початок ще 3 II тис. до н.е. та не менш стародавніми храмами та палацами, багато 3 яких входять в перелік світової спадщини ЮНЕСКО. Серед них, головний палац країни Кьонбоккун, усипальниця Чьонмьо, палац Чандоккун та інші храми.

Також, країна відома своїми щорічними фестивалями. Кожен 3 них, фінансується адміністраціями міст та орієнтовані не тільки на те, щоб забезпечити місцевим жителям гарний відпочинок та цікаве дозвілля, а й на залучення гостей міста та іноземних туристів до культури та традицій Кореї та ознайомлення їх 3 особливостями окремих регіонів країни. Розглянемо детальніше найпопулярніші 3 них.

(C) Анна Бєлєнкова, 2020 
Міжнародна виставка квітів у Кояні проходить з 1997 р. Цього року захід відбудеться вже в 12 раз. Щорічно виставку відвідує більш як 6200000 туристів з Кореї та інших країн, завдяки чому захід можна заслужено назвати основною квітковою виставкою Кореї міжнародного масштабу. Зимова пора в Кореї також багата на різноманітні фестивалі. Наприклад, Фестиваль форелі у Хвачхоні - це зимовий фестиваль, в районі Хвачхон провінції Канвон-до, де можна взяти участь в лові форелі, що мешкає в струмку, вода в якому кристально-чиста і замерзає раніше інших водойм. Захід проходить з 27 січня по 16 лютого, квиток на фестиваль для іноземців коштує 10000 вон $(\$ 8,45)$.

Загалом, можна сказати, що корейці з великою повагою ставляться до свят і відзначають їх барвисто і шумно. Корея вже відома на весь світ своїми неповторними та атмосферними фестивалями, стати глядачем і учасником яких, мріють мільйони туристів 3 усього світу.

Уже як декілька десятиліть Корея розвиває сферу туризму і робить в цьому великі успіхи. На сьогодні найпопулярнішими та найприбутковішими є такі види туризму, як: діловий туризм, медичний, гірськолижний, пляжний, освітній та культурний.

До кінця ХХ століття Республіка Корея увійшла в число економічних лідерів планети, створивши всесвітньо відомі марки на ринку автомобілебудування і ставши лідером в освоєнні Інтернету й інформаційних технологій. Не менш важливо, що вона зуміла створити демократичну політичну систему з вільними виборами. У цій країні захищені права людини та свобода слова. Так, фонд «Хансум» присвоїв Республіці Корея 16-е місце серед країн «Великої двадцятки», 1-е місце у сфері ефективності законодавчих дій та 17-е у просуванні політичної стабільності та ефективності. На тлі економічного зростання стає привабливою південнокорейська культура. Її популярність вийшла за рамки держави, особливо серед молоді в сусідніх азійських країнах. По всьому світу з кінця 1990-х рр. спостерігається «Халлю», або «K-Wave»- чимраз більша популярність всього корейського: від моди до кухні. Все це, на думку експертів, $є$ ресурсом для створення «м'якої сили», використовуючи яку, Республіка Корея починає проєктувати свою роль в міжнародних відносинах і глобальних інформаційних мережах.

На національному рівні питаннями розвитку туризму в країні займається Міністерство культури й туризму Республіки Корея. Розширення географії та обсягу поїздок громадян за кордон, залучення в країну інтуристів розглядається корейським урядом як важлива ланка в процесі подальшої інтеграції країни у світову спільноту і $є$ одним з пріоритетних напрямків його діяльності. Для практичного вирішення цих завдань в структурі міністерства в 1962 р. була створена Корейська національна організація розвитку туризму (Korean National Tourism Organization - KNTO). Організація веде статистику поїздок південнокорейських громадян за кордон, відвідування країни іноземними туристами.

Зараз найбільшим партнером Південної Кореї з обміну туристами $є$ сусідня Японія. Японські туристи приїжджають для того, щоб провести тут відпустку, а корейці їдуть до Японії як для відпочинку, так і з діловими цілями, а також для того, щоб відвідати своїх родичів і друзів. Багато туристів обирають Корею, тому що за рівнем злочинності це одна 3 найбезпечніших країн у світі. Тут практично немає наркоманії (наркотики знаходяться під абсолютною забороною), випадки кишенькових крадіжок або нападу вкрай рідкісні, викрадення автомобіля досі вважається сенсацією, а традиційна мораль суспільства настільки сильна, що зустріти випадки відкритого хамства або грубості майже неможливо.

Отже, Південна Корея - унікальна країна, де переплітається сучасна високотехнологічна ера 3 древніми будівлями, що ретельно оберігаються державою. Можна 3 впевненістю сказати, що в цій країні туристу завжди буде що робити й на що подивитись. Тут, також, є широкий вибір різної туристичної діяльності - від гірськолижного спорту до шопінгу. Розуміючи свої сильні сторони Республіка Корея, активно розвиває свою сферу туризму та просуває себе у світі як один з головних центрів ділового, медичного, а головне культурного туризму. Зокрема, медичний туризм набуває все більшої популярності не лише у сфері пластичної хірургії, а й в діагностиці, стоматології, дерматовенерологія та лікуванні тяжких хвороб. Крім того, в жодній країні він не має такої потужної державної підтримки, як в Південній Кореї.

Аналіз функціонування туристичної індустрії Кореї пояснює, чому ця країна домоглася таких високих показників розвитку туризму. Здебільшого це результат високого рівня підтримки туристичної індустрії з боку держави, як фінансової, так і організаційної. У Кореї вироблено чітке позиціювання видів туризму, що забезпечує високу міжнародну конкурентоспроможність індустрії на світовому ринку. Крім того, важливу роль грає високий рівень розвитку транспортної інфраструктури. Навіть в період кризи 1997 р. більшу частину позики у МВФ країна направила на розвиток транспортної інфраструктури, що в чималому ступені сприяло виходу з кризи. Корея забезпе- 
чила низькі транспортні витрати усередині країни з безліччю пільг, в тому числі й для туристів. Південна Корея використала для залучення туристів всі інструменти маркетингу на 100\% - від івент-маркетингу і знижок для туристів до всіляких пільг для малого бізнесу. Варто зазначити, що основою для розвитку міжнародного туризму послужив, насамперед, розвиток масового внутрішнього туризму.

Також, важливими факторами успіху є високий рівень безпеки перебування туристів на території країни та активна позиція країни в міжнародних туристичних організаціях. Держава активно сприяє туризму, спрощуючи візовий режим з багатьма країнами та надаючи безліч програм навчання, стажування та працевлаштування для іноземних студентів.

Поширене раніше уявлення про Корею як маленьку країну змінилося: зараз Корея є привабливою туристичною дестинацією. Підвищилася цінність бренду Південної Кореї, а також зросла гордість корейців за свою країну. Надалі Республіка Корея готова розвивати туризм $з$ ще більшим розмахом і досягти ще більших успіхів в цій cферi.

Список використаних джерел і літератури:

1. Дворец Кёнбоккун. URL: https://russian.visitkorea.or.kr/rus/ ATT/3 2 view.jsp?cid=336027.

2. Достопримечательности Сеула. URL: https://tonkosti.ru/\%D0\%94 $\%$ D0\%BE\%D1\%81\%D1\%82\%D0\%BE\%D0\%BF\%D1\%80\%D0\%B8\%D $0 \%$ BC $\%$ D0\%B5\%D1\%87\%D0\%B0\%D1\%82\%D0\%B5\%D0\%BB $\%$ D $1 \%$ $8 \mathrm{C} \% \mathrm{D} 0 \% \mathrm{BD} \% \mathrm{D} 0 \% \mathrm{BE} \% \mathrm{D} 1 \% 81 \% \mathrm{D} 1 \% 82 \% \mathrm{D} 0 \% \mathrm{~B} 8 \% \mathrm{D} 0 \% \mathrm{~A} 1 \% \mathrm{D} 0 \% \mathrm{~B} 5$ $\% \mathrm{D} 1 \% 83 \% \mathrm{D} 0 \% \mathrm{BB} \% \mathrm{D} 0 \% \mathrm{~B} 0$

3. Как Корея за 40 лет из отсталой аграрной страны стала технологическим лидером. URL: https:/www.vedomosti.ru/partner/ articles/2019/02/14/793589-futuristicheskaya-volna.

4. Королевская усыпальница Чонмё. URL: https://russian.visitkorea. or.kr/rus/ATT/3_2_view.jsp?cid=336035.

5. Международная выставка цветов в Кояне. URL: https://russian. visitkorea.or.kr/rus/ATT/3_5_view.jsp?cid=336472.

6. Південна Корея: Загальні відомості про країну. URL: http://www. big-lib.com/book/50 Ekonomichna i socialna geografiya zarybijnih krain/5407 Pivdenna Koreya.

7. Фестиваль форели в ледяной стране Хвачхон. URL: https://russian. visitkorea.or.kr/rus/ATT/3_5_view.jsp?cid=917854.

\section{Анастасія Бонь}

студентка 4 курсу

Начіональний університет «Острозька академія»

\section{ВИАОВИЩНО-РОЗВАЖАЛЬНІ ПРОГРАМИ В ШОТААНАІЇ ЯК ОАИН 3 РІЗНОВИАІВ НОВИХ ВИАІВ ТУРИЗМУ}

Шотландці - це досить весела нація, з гордістю шанують свої традиції, зацікавлені в своїй історії. Тому не дивно, що крім офіційних і національних свят, широкого поширення набули різні тематичні фестивалі в Шотландії. Наприклад, в Единбурзі з початку зими і майже до самого кінця осені змінюють один одного різні фестивальні дії, де можна продемонструвати свій талант, дізнатися чи спробувати щось новеньке.

Шотландці не забули свої язичницькі традиції, незважаючи на християнство. I коли в Свропі і Великобританії суспільну увагу присвячено більше Різдву, то в Единбурзі святкують саме Новий рік, або скоріше останній день року, що минає - Хогманай. У ці дні Единбург відвідує до 300 тисяч туристів, місто перетворюється в галасливу карнавальну вечірку з вуличними виступами, конкурсами та різноманітними шоу, в яких можуть взяти участь і глядачі [2].

Найвідоміший у світі фестиваль військових оркестрів дає прекрасну можливість познайомитися 3 найяскравішими проявами шотландської культури. Королівський фестиваль військових оркестрів в Единбурзі невипадково отримав неофіційний титул «головне шоу Шотландії». 3 моменту виникнення фестивалю в 1950 році тут виступили музиканти, танцюристи та артисти 348 країн світу, а його відвідувачами стали понад 14 мільйонів чоловік. Це свято проходить також в Австралії та Новій Зеландії. Крім цього, наглядачів чекає масштабна театрально-танцювальна постановка, що розповідає про історію та культуру Шотландії. Фіналом цього фестивалю стає загальне дефіле оркестрантів і грандіозний салют. Ціна квитків на Единбурзький фестиваль - від 31 фунта [1]

На честь дня небесного захисника Шотландії в країні щорічно влаштовують всенародні торжества з яскравим національним колоритом. День Святого Андрія, якого ще називають Saunt Andra's Day,

(C) Анастасія Бонь, 2020 
є одним з найважливіших національних фестивалів Шотландії, нарівні з Хогманай. Символ святого - Андріївський хрест навіть ліг в основу шотландського прапора і увійшов в число найбільш пізнаваних державних символів. Сьогодні День Святого Андрія стає початком сезону великих зимових свят в Шотландії. Основні урочистості 3 приводу Дня Святого Андрія в Шотландії проходять в столичному Единбурзі. У цей день місто стає ареною масових народних гулянь, лейтмотивом яких стає прославляння традиційної шотландської культури через музику, танцювальні уявлення і гастрономічні заходи. На відкритті свята, де щорічно збираються основні клани, прийнято пити коктейль Роб Рой. Наймасштабніше святкування St Andrew's Day можна спостерігати в старовинному місті СентЕндрюс на східному узбережжі Шотландії, де за переказами зберігаються мощі апостола [2].

Единбурзький Fringe - найбільший в світі фестиваль мистецтв. У серпні фестиваль «Фріндж» («Окраїна») збирає в шотландській столиці найдивовижніших, а, часом, і відверто дивних артистів 3 семи континентів. Тисячі вуличних музикантів, танцюристів, жонглерів, фокусників, коміків і просто фріків перетворять центральні вулиці Единбурга в подобу величезної пересувної ярмарки. На три тижні місто наповниться екстравагантними вбраннями, яскравими фарбами афіш, галасливими натовпами людей і феєричними шоу, що змагаються за увагу глядачів. Сьогодні Fringe вважається вітриною британської комедії та драми. Спонтанність і непередбачуваність - головна родзинка цієї дії [6].

Один 3 найстаріших кінофестивалів світу може похвалитися не тільки статусом запрошених зірок екрану, але і неповторним шотландським шармом. Edinburgh International Film Festival (EIFF) стартував в 1947 році як частина грандіозної програми Единбурзького фестивалю. За списком «зоряних» учасників Единбурзького кінофестивалю можна вивчати історію британської та світової кіноіндустрії. У різні роки в ньому фігурували такі знаменитості, як Джон X’юстон, Джин Келлі, Жак Таті, Дженніфер Лоуренс, Тільда Суїнтон, Еван Мак Грегор, Роберт Карлайл, Девід Кроненберг, Кейт Бланшетт, Клінт Іствуд та Шон Коннері .

Національні спортивні змагання «Горські ігри» - справжнє свято шотландської культури. Причому, взяти участь в ньому може кожен, навіть турист. Види змагань досить специфічні: метання каменів, молота, стовпів і снопів; перекидання вантажів через перекладину; богатирські змагання - боротьба «бекхолд» і перетягування каната. I, звичайно ж, конкурси з танців і гри на музичних інструментах
- скрипці і барабані. Горські ігри в Шотландії проходять в різних регіонах Хайленд і Лоуленда 3 травня по вересень. Всього на території Шотландії за сезон проводиться більше 60 «Горський ігор» [2].

Виготовляти віскі в Шотландії почали ченці спочатку в лікарських цілях, а пізніше до виробництва підключилися і місцеві фермери, замінивши виноград на ячмінь. Напій назвали «uisge beatha» (кельтс. «вода життя»). А вже потім англійці трансформували назву в uisge - uiskie - whisky [3]. Шотландський віскі трохи пахне димом i його непросто пити нерозбавленим. Найбільш відомі марки: White Horse, Chivas Regal, Cardhu, Johnnie Walker, Glenfiddich.

Віскі в Шотландії виготовляють в чотирьох основних регіонах його виробництва (Highlands, Speyside, Islands, Lowland) [4]. Bci peгіони можуть похвалитися своєю цікавою історією і неповторною природою, причому в кожному з них віскі мають свої особливі старовинні традиції. Мабуть, найцікавішими для відвідування можна назвати наступні:

1. Гленкінчі (Glenkinchie) - регіон Лоулендс знаходиться за пів години від Единбурга пропонують для туристів інформативні тури, прекрасна дегустація віскі з різних регіонів [5].

2. Ахентошен (Auchentoshan) - регіон Лоулендс, що знаходиться на околиці Глазго пропонує м'яке віскі потрійної перегонки.

3. Гленгойн (Glengoyne) - регіон Хайлендс пропонує тури досить пересічні, та й туристів чимало однак тут є чудова фішка - «урок майстра- блендера»: цікава лабораторія, де 37 сортів односолодового віскі за годину належить створити власний бренд. Ось коли розумієш: віскі - це мистецтво!

4. Едрадор (Edradour) - регіон Хайлендс. Найменша віскікурня в Шотландії, яка зберегла «фермерські» методи виготовлення.

5. Балвені (Balvenie) - регіон Спейсайд. Групи не більш 7 осіб проходять 3 дуже докладним туром по цеху, виробництві, бондарні (одне з двох місць в країні, де можна побачити обробку бочок) і знаменитому складу 24, де зберігаються рідкісні бочки [3].

6. Макаллан (Macallan) - регіон Спейсайд. Особливий акцент в турах зроблений на властивостях дубових бочок (у Макаллані навіть власні дубові ліси є). Дегустації прекрасні, з докладними поясненнями карти смаків. А оглядове вікно дегустаційної кімнати дивиться в кабінет Боба Далгарно, головного «нюхача», який відбирає бочки для розливу прямо на очах у туристів.

7. Аберлауер (ABERLOUR) - регіон Спейсайд. Двогодинні тури чудесні, спробувати дають все, починаючи від проміжних продук- 
тів (сусла, браги, свіжовигнаного спирту) до красивих витриманих сортів віскі.

8. Гленморанжі (Glenmorangie) - регіон Хайлендс. Віскікурня відноситься до експериментаторів: тут весь час пробують нові розливи і незвичайні бочки робить дегустації цікавими для знавців.

9. Спрінбанк (Springbank) - регіон Кембелтаун. Весь цикл виробництва, від вирощування ячменю до витримки, робиться тут. Візит сюди - дотик до історії [4].

\section{Список використаних джерел та літератури:}

1. Праздники в Шотландии. URL: https://travelcalendar.ru/category/ shotlandiya/

2. Календарь основных событий в Шотландии. URL:https://www. comeintour.com/eventsinscotland

3. Старинные вискикурни Шотландии. URL: https://holidaymtours. livejournal.com/249980.html

4. Виски-тур по Шотландии. URL: https://tcc.com.ua/countries/ great britain/hotels/viskityr_po_shotlandii/

5. Лучшие вискикурни Шотландии. URL: http://miss-tourism.ru/ luchshie-viskikurni-shotlandii.html

6. Рыжкин Ю.Е. Физическая рекреация в сфере досуга человека. URL: https://tourlib.net/statti_tourism/ryzhkin.htm

\section{Вікторія Ліщук,}

студентка 4 курсу

Національний університет «Острозька академія»

\section{РОЗВИТОК ІНАУСТРІЇ КУРОРТНО-ПАЯЖНОГО ТУРИЗМУ НА КАНАРСЬКИХ ОСТРОВАХ B XXI CTOAITTI}

Стрімкий розвиток туристичного бізнесу в наші дні дозволяє мандрівникам вибирати все більш незвичайні види туризму: підкорення гірських вершин, візити до значимих святинь світу, спуски по гірських річках - кожен може вибрати відпочинок до душі. Однак, незважаючи на таке різноманіття варіантів, найпопулярнішим видом відпочинку з року в рік все-таки залишається пляжний туризм. А Канарські острови, в свою чергу, є найчастішим вибором у любителів сонця і пляжного відпочинку, особливо тих, хто проживає в холодному європейському кліматі.

Канарські острови (ісп. Las Islas Canarias) - мальовничий архіпелаг островів вулканічного походження в Атлантичному океані, 3 круглорічними сонячними днями, ідеальним кліматом, смарагдовими долинами, химерними скелями і піщаними пляжами. Офіційно Канари - автономна провінція Іспанії, що складається 37 великих островів (Ієрро, Ла-Пальма, Ла-Гомера, Тенеріфе, Лансароте, ГранКанарія і Фуертевентура) і декількох маленьких.

Незважаючи на те, що Канарські острови належать Іспанії, атмосфера на островах не зовсім європейська. Туристи їдуть сюди за справжньою екзотикою: тропічними пейзажами, м'якими океанськими хвилями, чорними вулканічними пляжами і стиглими фруктами. На Канарах присутня також велика кількість унікальних доісторичних пам'яток, вулканів, водоспадів, «місячних» долин із застиглої лави.

Незважаючи на спільність походження і незначні відстані островів архіпелагу, кожен з них по-своєму унікальний, тому варто проаналізувати особливості кожного з Канарських островів.

Тенеріфе - найбільший з Канарських островів, своєю формою нагадує каченя, і $є$ найпопулярнішим серед туристів. Щоб справлятися 3 щорічними більш ніж трьома мільйонами туристів, які без-

\footnotetext{
(С) Вікторія Лімук, 2020
} 
перервним потоком прибувають на острів, на Тенеріфе було побудовано аж два аеропорти - на півночі та півдні. Тенеріфе - острів, так би мовити, універсальний: різні курортні містечка і селища відповідають вимогам різних вікових і соціальних груп відпочивальників, тому здійснити подорож на цей острів можна рекомендувати i тусовщикам, і пенсіонерам, і сім'ям із маленькими дітьми. До речі, саме Тенеріфе став першим островом, з якого почалося туристичне освоєння архіпелагу. Попри те, що острів має досить скромні розміри, клімат і природні умови в його північній і південній частинах відчутно різняться. Південь Тенеріфе більш сонячний, погожий, безвітряний і теплий, але в природному плані досить одноманітний.

Поряд зі столицею, Санта-Крус-де-Тенеріфе, великим туристичним центром північної частини острова $є$ місто Пуерто-де-ла-Крус, в межах якого знаходиться чотири пляжі. Кожен з них має свої особливості, зокрема і Плайя Хардін (Playa Jardin). Він рукотворний, але на відміну від Плайя-де-лас-Тересітас його не стали захищати від хвиль. Тому над пляжем часто майорить червоний прапор, який попереджає туристів про іноді небезпечне купання, зате для серферів тут створено ідеальні умови.

Загальним рахунком на Фуертевентурі 150 пляжів, сумарна довжина яких сягає 340 км. Острів Фуертевентура обирають поціновувачі спокійного відпочинку, або з сім'єю, а також досвідчені сервери. В додаток до цього на острові 3 тис. безхмарних годин щороку і тому зрозумілий вибір любителів серфінгу, дайвінгу, снорклінгу, плавання на байдарках і інших видів активного відпочинку, поширених на Фуертевентурі.

Як курорт, найбільшу популярність має півострів Хандія -південний край Фуертевентури, відокремлений від неї вузьким, шириною в п'ять кілометрів, перешийком. Саме на курорти Хандії припадає найбільша частина відвідувань туристів. Плайя-дель-Маль-Номбре (Playa del Mal Nombre) $\epsilon$ ще одним місцем, яке відмінно підходить для відпочинку з дітьми. Пляж 3 красивим золотистим піском, який відтіняється великою чорною галькою. На узбережжі, зовсім поруч з водою, є скелясті утворення, які під час припливу розділяють Плайя-дель-Маль-Номбре на кілька затишних бухт.

Гран-Канарія (Gran Canaria) - третій за величиною острів в архіпелазі. Форма острова - практично правильна окружність, завдяки чому дуже просто говорити про масштаби і відстані. Наприклад, діаметр острова - майже 50 км, а центральною точкою є давно згаслий вулкан Піко-де-лас-Ньевес.
Як і Тенеріфе, Гран-Канарію можна розділити на дві частини, які мають різний клімат: на півночі гірського хребта посушливо, на півдні - більш волого, тому більшість курортів розташовано саме на півдні. Найбільша туристична зона на острові - Маспаломас. Найкрасивішим і популярним пляжем цієї місцевості є Дюни Маспаломaca (Dunas de Maspalomas) - п'ятикілометрова смуга золотистого піщаного узбережжя і невелика пустеля, яка розкинулася поруч.

На о. Лансароте (Lanzarote) найчастіше приїжджають знімальні групи, а там сама природа постаралася над неймовірними декораціями. Ця фантастична місцевість $\epsilon$ територією національного парку Тіманфайя. Взагалі весь острів Лансароте з його вулканічними пустелями, печерами і кратерами охороняється ЮНЕСКО, як біосферний заповідник.

Якщо згадувати особливості місцевого клімату, то варто зазначити, що Лансароте найбільш прохолодний з усіх Канарських островів. Острів першим приймає на себе пасати 3 північного сходу Атлантики, які впливають на зміни погоди. Дощі тут нечасте явище, оскільки на острові немає високих гір, що затримують дощові хмари, тому сухих і сонячних днів на Лансароте більше.

Ла-Пальма (La Palma), як відомо, утворилася останньою з усіх Канарських островів тим же вулканічним шляхом, і на півдні острова до сих пір є ймовірність вивержень вулканів. Як і вищезгаданий о. Лансароте, Ла-Пальма також знаходиться в списку ЮНЕСКО, як світовий біосферний заповідник. Тут само, на цій горі, знаходиться однойменна обсерваторія, що займається дослідженнями Сонця, Чумацького Шляху і транснептунових об’єктів.

Якщо говорити про клімат Ла-Пальми, то він ідеально годиться для комфортного пляжного відпочинку. Субтропічний клімат пом'якшується за рахунок холодних північних вітрів і прохолодної Канарської течії. Вода в океані тримається на комфортній позначці в 22 градуси навіть в зимові місяці, повітря влітку прогріте до 25 градусів.

Одним 3 найпопулярніших курортів $є$ дуже сонячний (близько 3300 годин на рік) Пуерто-Наос, який може похвалитися найдовшим на всій Ла-Пальмі пляжем, чистим чорним піском і розвиненою туристичною інфраструктурою.

Передостанній за величиною острів Канарського архіпелагу ЛаГомера (La Gomera) розташувався поруч з Тенеріфе, 3 якого його навіть можна побачити неозброєним оком, якщо забратися куди вище - наприклад, на вулкан Тейде. У цього клаптика суші така багата історія, культура та природа, що за кілька годин перебування на ньо- 
му неможливо все охопити і взагалі скласти для себе уявлення про унікальність Ла-Гомери.

Як висновок можна сказати, що Канарські острови є універсальними для різних категорій туристів, які прагнуть не лише відпочити на пляжах островів, а й зайнятись активним відпочинком, серфінгом, віндсерфінгом,цікавими екскурсіями або пізнанням культури, архітектури, природи, відмінностей від класичної іспанської ментальності, тощо.

Список використаних джерел та літератури :

1. Испания. Канарские острова. UR.: https://100dorog.ru/guide/ articles/101236/

2. Канары. Какой остров выбрать? URL: http://malpatravel.com/ novosti/stati/kanarskie-ostrova-kakoy-vybrat.html

3. Канарские острова -основные курорты и районы, экскурсии и достопримечательности, музеи, отзывы туристов о Канарских островах. URL: https://tonkosti.ru/

4. Канари. URL: https://www.piligrim.lviv.ua/blog/kanari

5. Пляжи Канарских островов. URL: https://www.ice-nut.ru/spain/ spain05902.htm

6. Number of international tourists arriving in Spain in 2019, by country of residence. URL: https://www.statista.com/statistics/447683/foreigntourists-visiting-spain-by-country-of-residence/

7. Number of tourists in the Canary Islands 2019, by island. URL: https:// www.statista.com/statistics/706967/canary-islands-tourist-numbers-byisland/

\section{Владислав Мойсеєць,}

студент 4 курсу,

Начіональний університет «Острозька академія»

\section{БРЕНАОВА ТА МАРКЕТИНГОВА СТРАТЕГІЯ ТУРИСТИЧНОГО РИНКУ УКРАЇНИ}

Туризм - один з небагатьох видів вітчизняного бізнесу, який останні роки має тенденцію розвитку. Розвиток туризму в Україні сприяє створенню сприятливого організаційно-правового та економічного середовища для розвитку цієї галузі, формування конкурентоспроможного на світовому ринку вітчизняного туристичного продукту на підставі ефективного використання природного та історико-культурного потенціалу України, забезпечення ії соціально-економічних інтересів і екологічної безпеки.

Сьогодні туристична галузь має величезні перспективи розвитку. Однак туризм також має велику залежність від зовнішніх і внутрішніх факторів, особливо під впливом наслідків світової кризи. Україна, завдяки відкритому війському конфлікту на Донбасі, залишається непривабливою для іноземців завдяки сформованому за останні три роки негативному іміджу держави, відвідування якої може бути небезпечним для життя і здоров'я туристів. Тому актуальним завданням виступає формування ефективної системи антикризового управління з урахуванням сучасних проблем в туристичній сфері.

За останні три роки в туристичній галузі України сталося багато змін як позитивних, так і негативних. Головним і поки єдиним позитивним моментом можна вважати прийняття «Стратегії розвитку туризму і курортів на період до 2026 року», в якій прописані п’ять головних векторів розвитку даної галузі: безпека, правова база, інфраструктура, людські ресурси, маркетинг.

Негативних моментів, на жаль, набагато більше. До них можна віднести:

- політичну нестабільність і проведення антитерористичної операції в східних регіонах (АТО);

- відсутність міністерства з розвитку туризму, працює тільки відповідний департамент, який має обмежений бюджет і повноваження; фінансування галузі за залишковим принципом;

(C) Владислав Мойсеєиь, 2020 
- низький рівень мотивації суб'єктів туристичної діяльності 3 боку держави; нерівномірний розвиток туристичних дестинацій і інше.

Однією з основних галузей діяльності туристичного підприємства являється маркетингова стратегія, яка гарантує переважання у боротьбі конкурентів, які досягаються шляхом надавання туристичних послуг, які найбільше відповідають вимогам клієнтів, кращого рівня обслуговування клієнтів, а також аналіз споживачів для найбільш вдалого підбору продуктів.

Довготривале функціонування будь-якого туристичного підприємства на ринку визначається не стільки за якістю послуг, ціною та його розмірами, скільки за його перевагою над іншими підприємствами. Тобто саме конкурентоспроможність являється основним індикатором підбору маркетингової стратегії.

Маркетинг інфраструктури служить найважливішим і в довгостроковому плані найбільш стабілізаційним елементом, оскільки інфраструктура - це опорний каркас і фундамент одночасно. Надійне енергопостачання, якісна освіта, чиста питна вода, розвинені комунікації, безпека на вулицях - ознаки розвиненої інфраструктури. Ïї наявність ще не гарантує регіонального зростання, але їі відсутність або поганий стан робить таке зростання неможливим.

Сьогодні імідж України можна оцінити більше як негативний чим позитивний. Склалося це звичайно не тільки від подій 2014 року, а й від економічних проблем та того, що Україна не використовує всі свої ресурси на туризм, хоч їх і має. В України немає чіткої позиції щодо туризму та його управлінням. Та найголовніше, що в Україні немає міністерства туризму.

Питання фінансування завжди було і залишається болючим i жалюгідним. Попри позитивні зміни шляхом прийняття стратегії розвитку туризму, ситуація майже не змінилася. I хоча вперше в державний бюджет було закладено 30 млн грн витрат на маркетинг і просування туристичного бренду під назвою Україна, але насправді це мізер, у порівнянні з тим, які кошти виділяють на розвиток туризму інші європейські країни. Так, наприклад, Грузія, в десять разів менша за Україну, тільки на рекламу виділяє щорічно близько 18 млн євро. А світова практика показує, що планувати витрати на туристичний маркетинг потрібно з розрахунку 4-6 доларів на кожного прибулого іноземця. Для України відповідно це повинно бути більше 50 млн євро на рік. Очевидно, що українським туристичним підприємствам потрібно розраховувати тільки на себе, не тільки в збільшенні своїх доходів, але і в поліпшенні туристичного іміджу України й, тим самим, приваблювати іноземних відвідувачів.

Одна з головних проблем і негативних тенденцій туризму в Україні - це нерівномірний розвиток туристських дестинацій. Львів, Одеса, Київ, Карпати - найбільші, відомі на весь світ, дестинації та головні поповнювачі бюджету

Яку б модель брендингу не обрала для себе Україна, людям потрібно говорити правду про країну, пропагувати іiї цінності. Головним завданням має бути показати, що Україна це європейська держава з родючою землею, сприятливими кліматичними умовами.

Підсумовуючи вищесказане, можна зробити висновок, що в сучасній науці приділено велику увагу питанню антикризового управління туристичним підприємством. Багато праць присвячено маркетинговому антикризовому управлінню. Але проблема виходу з кризи туристичних компаній України, а також можливості маркетингу і брендингу, які актуальні для сучасного українського туристичного ринку, залишаються недостатньо висвітленими. На жаль, сьогодні практика українських підприємств свідчить про неефективне використання або повне ігнорування маркетингових і брендингових інструментів

\section{Список використаних джерел та літератури:}

1. Антонюк О. Міжнародний імідж та іміджева політика держави. Наукова періодика України URL: www.nbuv.gov.ua/Antonuk_210.htm

2. Бобрицька Н., Кирилова А. Маркетингове антикризове управління туристичними підприємствами в сучасних умовах. Економіка: реалії часу. 2014. № 5 (15). C. 41-46

3. Васюкова O. Моделі управління іміджем держави. URL: http:// dspace.univer.kharkov.ua/bitstream/123456789/6781/2/Vasyukova.pdf.

4. Волошина М. Анализ рынка туристических услуг в Украине: проблемы и перспективы. URL: https://koloro.ua/blog/issledovaniya/ analiz-rynka-turisticheskikh-uslug-v-Ukraine.html

5. Гуляєв В. Організація туристської діяльності. М.: Нолидж, 1996. 312 с.

6. Державна служба статистики України: офіційний URL: http:// www.ukrstat.gov.ua.

7. Котлер Ф., Асплунд К., Рейн И., Хайдер Д. Маркетинг мест. Привлечение инвестиций, предприятий, жителей и туристов в города, коммуны, регионы и страны Европы. СПб. : Стокгольмская школа экономики в Санкт-Петербурге, 2005. 376 с.

8. Кудла Н. Про застосування комплексу маркетингових заходів у сільському туризмі 2011. № 2. С. 79-85.

9. Кулєшова Н. Маркетингова стратегія як інструмент ефективної діяльності підприємства 2007. С. 131-142. 


\section{Ірина Партико, \\ студентка 4 курсу}

Начіональний університет «Острозька академія»

\section{ПРОБЛЕМИ ТА ПЕРСПЕКТИВИ РОЗВИТКУ ЛІКУВААЬНО-ОЗАОРОВЧОГО ТУРИЗМУ У ШВЕЙЦАРСЬКІЙ КОНФЕАЕРАЦІї}

Експерти Всесвітнього економічного форуму в Давосі оприлюднили рейтинг конкурентоспроможності 130 країн світу у сфері туризму. Кращою країною за співвідношенням вартості відпочинку, безпеки, екології та ще 11 критеріям визнана Швейцарія, до п’ятірки кращих держав також увійшли Австрія, Німеччина, Австралія та Іспанія.

Розвиток лікувально-оздоровчого туризму у Швейцарії багато в чому визначився географічним положенням країни й наявними природними ресурсами.

Природні ресурси мають численні функції, проте однією з найважливіших є можливість їх використання як засіб відновлення фізичних і духовних сил людини. Природні туристські ресурси слід розглядати як ресурси, які активно використовуються для збереження або підтримки здоров’я людини. До них можна віднести як весь природний комплекс, так і окремі компоненти природи. Однак ступінь використання природних ресурсів може бути різний і залежить головним чином від спеціалізації регіону. Велике значення при цьому мають такі фактори, як географічне положення, ландшафт, клімат, гідромінеральна база і унікальні природні лікувальні фактори. Наявність усіх цих природних чинників і роблять лікувально-оздоровчий туризм Швейцарії одним із головних джерел надходжень до державного бюджету країни [7, с. 42].

Відмінна риса швейцарських гірськолижних курортів - високий рівень сервісу і комфорту, а швейцарський рівень підготовки трас вважається еталоном у всьому світі. Велика кількість сучасних витягів, їх висока пропускна здатність і відсутність черг навіть в самий розпал сезону гарантує прекрасне катання з листопада по квітень, а на курортах Цермат і Саас-Фе - навіть влітку. Але існують і проблеми в цій галузі.

(C) Ірина Партико, 2020
По-перше, у Швейцарії від кризи потерпають у першу чергу гірськолижні курорти, адже ощадливі європейські туристи обирають дешевші Австрію та країни Східної Свропи. Наприклад, у регіоні Енгадін в модернізацію фунікулерів за останні роки інвестовано близько 60 мільйонів франків. Дещо згодом у містечку планують розширити мережу лижних трас. «Зароджуються» плани нових проєктів. Реалізувати ці плани вдасться лише у випадку, якщо кількість відвідувачів не зменшуватиметься [11]

На підтримку того, що курорти Швейцарії є найдорожчими, свідчить наступний факт. Найбільше товариство автомобілістів Німеччини - ADAC - порівняло актуальні ціни у п'яти країнах, які полюбляють європейські туристи взимку: Австрії, Італії, Німеччині, Франції та Швейцарії. Вийшло, що в Німеччині за тиждень у готелі, включно з лижними перепустками, двоє людей заплатять в середньому на 798 євро менше, ніж у Швейцарії. Згідно з дослідженням, серед згаданих країн Німеччина лідирує за дешевизною готелів, в середньому відпочинок тут обійдеться в 929 євро на тиждень на двох осіб. За нею йде Італія (1296 євро), Австрія (1414 євро) та Франція (1702 євро). Найдорожчою вийшла Швейцарія, де лижний відпочинок коштує 1727 євро [11].

Особливо вплинула на розвиток лікувально-оздоровчого туризму світова фінансова криза 2008 року. Саме тоді навіть найпопулярніші курортні зони втратили близько третини своїх відвідувачів.

Для привертання більшої кількості туристів на курортах Швейцарії сьогодні існує велика кількість знижок. Це свідчить про те, що підприємцям на лижних курортах несолодко. Майже всі туристичні послуги вже стали дешевшими. Денний абонемент на канатну дорогу тепер можна придбати за 25 франків, а не 73, як раніше. Приблизно стільки ж він коштує у країнах Східної Свропи. Знижки мали б стати «приманкою» для молоді та сімей [11].

Суттєво знизити ціни на нічліг та харчування у Швейцарії складно, тому підприємці роблять ставку на якість. Як зазначає відомий в країні підприємець Міхаель Вагнер: «У нас надто дорогі витрати на проживання. 3 цим ми нічого не можемо зробити. Тож ми намагаємося пропонувати високу якість послуг». Для роботи у його готелі він найняв близько 60 осіб. До фінансової кризи швейцарець працював у банківському секторі у Франкфурті-на-Майні. Згодом він повернувся на батьківщину і відкрив свій готель. Його працівники здебільшого походять 3 Португалії, Греції та країн Східно Свропи. «Мінімальна зарплата, відповідно до наших законів, починається 33500 франків брутто. Чим більше досвіду та чим вища 
кваліфікація, тим, відповідно, вищою є оплата», - пояснює підприємець [5, с. 183].

Високий курс франка (а отже і значна вартість туристичних послуг) $є$ основною проблемою для лікувально-оздоровчого туризму Швейцарії. Тим часом, швейцарські курорти посилено шукають шляхи виходу на нові ринки. Постійних відвідувачів намагаються «втримати» новими ідеями. Не втрачають надію і «заманити» нових клієнтів на швейцарські широти. Хоча місцеві мешканці песимістично заявляють, що пік туризму уже в минулому. Можливо тому швейцарські підприємці взяли курс на дальні ринки. Останнім часом дедалі більше гостей приїжджають зі Сполучених Штатів, Бразилії або Китаю. За останні роки їхня частка серед туристів підвищилася до 30 відсотків.

Поточний туристичний баланс у Швейцарії сьогодні позитивний. Однак не всі гроші, витрачені іноземними туристами в країні перебування, можуть автоматично поліпшити ії платіжний баланс. Світовій практиці відома низка витрат, які несе сторона, яка приймає туристів. В першу чергу витрачаються предмети й товари, звичні для іноземного туриста, але не вироблені або не споживані в країні перебування, починаючи від будівельних і оздоблювальних матеріалів готелів, готельного та ресторанного обладнання, меблів, спортивного інвентарю і закінчуючи харчовими продуктами, напоями та сувенірами. Збільшення прийняття іноземних туристів створює додаткове навантаження на місцеву інфраструктуру: водо- та електропостачання, каналізацію, прибирання сміття, дороги, транспорт, зв’ язок, службу безпеки [8].

Виявляється необхідність розширення і розвитку аеропортів, вокзалів, морських або річкових портів, готелів, доріг і т.д., для чого необхідно інвестувати величезні кошти. У країнах, що розвивають індустрію туризму, це робиться, як правило, коштом іноземних інвесторів.

Залучення ж закордонних інвесторів призводить до необхідності повернення частини отриманих ними доходів у країну інвестора. У ряді країн розвиток туризму призводить до необхідності залучення іноземних сезонних робітників, що також викликає додаткові валютні витрати та навантаження на місцеву сферу обслуговування. Для держави важливо так збалансувати доходи, одержувані від в'їзного туризму, з витратами на нього (включаючи повернення валюти країні-інвестору, довгострокові витрати на будівництво та підтримку хорошого стану готелів, доріг, аеропортів, засобів зв'язку, підготовку персоналу для створення комфортних умов перебування іноземним туристам), щоб в кінцевому підсумку забезпечити стійкий позитивний платіжний баланс країни за статтею «Туризм» [2, с. 183].

Жорстка конкуренція на ринку європейського туризму та проблеми туристичної галузі Швейцарії потребують їі підтримки з боку держави.

Підтримка туристичної сфери полягає у створенні умов для підвищення конкурентоспроможності швейцарського туристичного бізнесу шляхом створення та модернізації туристичної інфраструктури, підвищення якості та різноманітності туристичних послуг, популяризації швейцарських курортів.

У 2017 р. було реалізовано цілу низку проєктів у сфері туризму, завдяки яким суттєво зросла туристична привабливість низки лікувально-оздоровчих центрів. Серед успішних проєктів, наприклад, можна назвати організацію в літні місяці в м. Бад-Рагац безкоштовного для відвідування щоденного світлового шоу, що залучає в місто туристів з сусідніх районів. Даний захід проводиться в рамках спільного проєкту, учасниками якого стали місцеві підприємства ресторанного та готельного бізнесу, адміністрація міста та агентство туристичного розвитку м. Бад-Рагац.

У рамках нової регіональної політики надано сприяння будівництву великого велнес-центру при одному з готелів в невеликому місті Ла-Шо-де-Фон. Суспільне значення даного проєкту, що дозволяє використовувати державні кошти для його будівництва, обумовлено тим, що даний центр доступний не тільки для тих, хто проживає в готелі, але і для гостей міста, що сприяє туристичній привабливості району, зростанню відвідуваності даного туристичного центру, а у підсумку збільшення доданої вартості, створюваної у сфер туристичних послуг [4].

У 2019 р. стартував ще один важливий проєкт, в рамках якого буде запущена нова система підбору кадрів, орієнтована на підприємства туристичної інфраструктури, що працюють в сезонному режимі (що вельми характерно для Швейцарії). Спеціальний інтернет-pecypc («Match-Making») сприятиме легшому і швидшому налагодженню контактів між роботодавцями й сезонним найманим персоналом. За підсумками тестування даного ресурсу, яке проходило у 2017 р. в кантонах Граубюнден і Тічіно, було прийнято рішення про запуск проєкту на загальнодержавному рівні. Проєкт отримав схвалення і фінансується коштами, що виділяються державою для реалізації нової регіональної політики [1].

У 2019 році продовжена робота над великим інфраструктурним проєктом з прокладання високовольтних ліній і оптоволоконних ка- 
белів в гірському районі Енгадін кантону Граубюнден, менш економічно розвиненого в порівнянні з іншими кантонами.

Зараз в області підтримки туризму у Швейцарії йде робота по 300 аналогічним проєктам. За час першого етапу реалізації нової регіональної політики (2008-2015рр.) число бізнес-проєктів, яким була надана підтримка, досягло 1800. Потенційна можливість фінансування проєкту з даних коштів залежить від стратегічних цілей, які визначає кантон, закріплюючи їх у власній програмі реалізації нової регіональної політики [10].

Не лише державна підтримка туристичної галузі зі здоров'я прогнозує, що до 2022 року туризм і сектор охорони здоров'я стануть одним з найважливіших секторів економіки у світі. У країнах, що розвиваються, 3 найбільшими відправними ринками, збільшення частки населення похилого віку є найважливішою демографічною тенденцією. Більш досвідчені літні люди в їх подорожах збільшують попит на галузь індустрії оздоровчо-лікувального туризму. У суспільствах соціального забезпечення також зростає потреба пов'язувати самофінансовані медичні послуги з туристичним досвідом. Такі тенденції й сприятимуть зростанню попиту на послуги лікувально-оздоровчого туризму Швейцарії

Отже, як вважають менеджери туристичні організації та експерти у галузі туризму, лікувально-оздоровчі події є одним з найдинамічніших напрямів розвитку у сфері туризму. Лікувально-оздоровчий туризм $\epsilon$ найбільш бажаним видом туризму, тому що він $\epsilon$ помірним по сезонності й також за середньою тривалістю перебування, високим рівнем витрат гостя і легким примиренням з принципами сталого туризму.

\section{Список використаних джерел та літератури:}

1. Абрамов В.В. Історія туризму: підручник. Х: ХНАМГ, 2010. 294 с.

2. Александрова А.Ю. Международный туризм : учебник для студентов вузов, обучающихся по специальности «География». М. : Аспект Пресс, 2004 (ОАО Можайский полигр. комб.). 463 с.

3. Алєшугіна Н.О. Основи туристичного країнознавства : опорний конспект у таблицях і схемах: навч.-наочн. посіб. Ніжин: НДУ, 2010. $351 \mathrm{c}$.

4. Аржанов Н.П. Посредники: история курортного лечения в Швейцарии. Провизор. 2003. № 22. С. 37-40.

5. Бабкин А.В. Специальные виды туризма: учеб. пособие. Ростов на Дону: Феникс, 2008. 154 с.

6. Ветитнев А.М. Курортное дело. М.: КНОРУС, 2017. 212 с.
7. Ветитнев А.М. Курортное дело: учебное пособие. М. : КНОРУС, 2006. $320 \mathrm{c}$.

8. Державна служба туризму і курортів URL: http://www.tourism.gov. ua/PublicationsList.aspx?id=46

9. Державний комітет статистики України: офіційний сайт URL: www.ukrstat.gov.ua.

10. Ефимова В.М. Курортология, антропоклиматология, лечебный туризм: словарь-справочник. Симферополь: АнтиквА, 2010. 260 с.

11. Міжнародний туристичний портал TripAdvisor. URL: http://www. 


\section{Олег Височанський,}

\section{студент 4 курсу}

Начіональний університет «Острозька академія»

\section{ВПЛИВ ОАМПІЙСЬКИХ ІГОР НА РОЗВИТОК ТУРИЗМУ В КРАЇНАХ ПРОВЕАЕННЯ}

Олімпійські ігри - наймасштабніший тип спортивних заходів. Вони збирають в одному місці тисячі спортсменів, що змагаються у сотнях спортивних дисциплін. На це приїжджають подивитись мільйони глядачів та сотні мільйонів спостерігають за екранами своїх телевізорів. До Олімпійських ігор прикута неабияка увага, і навколо них обертаються величезні кошти. Все це, так чи інакше, впливає на туризм, особливо для країн, в яких ці ігри проводяться.

Провівши дослідження організації та проведення чотирьох Літніх Олімпійських ігор, а також загальні характеристики проведення Паралімпійських та Всесвітніх ігор, можна виявити, що, по-перше, організаторів Олімпійських ігор переслідують дуже схожі проблеми. Дорожнеча змагань звісно є проблемним моментом, але не є проблемою сама по собі, адже усі організатори очікують вигодою перекрити затрати. Проблема в тому, що це рідко виходить. Передусім це відбувається через неефективне використання ресурсів та недостатньо продуману стратегію щодо проведення змагань.

Ігри в Пекіні 2008 та в Ріо-де-Жанейро 2016 р., окрім того, що відбувались не на території Європи мають ще ряд спільних ознак. Перша 3 них, і найочевидніша - бажання, принаймні задеклароване, підняти за рахунок проведення Олімпіади індустрію туризму на новий рівень, а також покращення устрою та інфраструктури в місті проведення. Спільний також той факт, що частина запланованого не справдилась. Різняться обсяги того, чого вдалось досягнути завдяки проведенню Олімпіади. У Китаї завдяки більш чіткій та ефективній організації вдалось отримати певні довгострокові здобутки, натомість, в Бразилії спостерігались лише тимчасові піднесення показників під час проведення Олімпійських ігор. Схожа проблема для обох олімпіад - наявність незатребуваних, дорогих спортивних об' єктів по завершенню ігор. Суми вкладені в підготовку і організацію змагань значно різняться. Хоч організація Ріо і перевищувала свій початково запланований бюджет, однак є суттєво меншою, ніж та, що вклали організатори Пекіну-2008. Це звісно, пояснюється різницею у ресурcax, якими володіють дві держави. Через цю різницю та відмінність у способах управління держави та культурно-суспільних особливостей життя, різняться і підходи до підготовки ОI та кінцевий результат. Через це важко на основі досвіду цих двох Олімпіад виділити особливості проведення Олімпійських ігор поза межами Європи.

Олімпійські Ігри в Лондоні 2012, в Афінах 2004 р., хоч і об’єднані спільним регіоном проведення, мають дуже мало спільних рис Мова йде передусім про їх ефективність. За рахунок кращих ресурсів, в тому числі уже наявної інфраструктури високого рівня, наявного досвіду, більш ефективної та добросовісної підготовки, Олімпійські ігри в Лондоні значно виграють у Олімпіади в Афінах за показниками відвідуваності, коротко- та довгострокового прибутку, покращення туристичних показників. Організатори Лондонської олімпіади продемонстрували яскравий приклад ефективної Олімпіади, вдало розділивши ресурси та заздалегідь спланувавши подальшу долю усіх об'єктів, які були задіяні на Олімпійських іграх Відповідальні за Олімпіаду 2004 р. вдалися до тих само помилок, які допускали, до того і після, організатори Олімпіад та спортивних форумів у інших частинах світу. Обидві країни після проведення змагань збільшили туристичний потік, однак Велика Британія отримала більш помітний та стабільний зріст кількості відвідувачів. Велика Британія довела, що навіть для успішного міста чи країни можна отримати певний зиск та серйозний ріст туристичних показників за грамотної та ефективної організації.

3 чотирьох розглянутих Олімпіад лише одну можна назвати стовідсотково вдалою. Мова йде, про Лондонську Олімпіаду 2012 р. Ї̈і можна назвати скоріше виключенням із правил, де вдало поєднались фактори наявних фінансових та інфраструктурних ресурсів із ефективною організацією. Саме це дало змогу відчути найбільший, як прямий так і непрямий, прибуток. Зміни у туристичних потоках спостерігались у кожній країні проведення, однак саме у Великій Британії вони були найбільш стабільними та помітними. Також певні успіхи мала й Пекінська олімпіада внаслідок чіткого управління, однак там були вкладені значно більші кошти, ніж в Ігри у Лондоні. Частково недоцільність Олімпіади можна виявити вже на етапі обрання міста. Адже деякі спортивні споруди будуть незатребуваними там, де непопулярні ті чи інші види спорту, якщо, звичайно, їх не переобладнати.

Щодо нових спортивних форумів, таких як Всесвітні ігри, Параолімпійські та Юнацькі Олімпійські ігри, то їх популярність, очевид-

(с) Олег Височанський, 2020 
но, поки що помітна мала, але стабільно зростає. Також, відповідність цих форумів до світових тенденцій дає їм перевагу у майбутньому.

Всесвітні ігри, Юнацькі Олімпійські та Параолімпійські ігри відносно нові явища у спортивному туризмі, зокрема, та у світовому туризмі, загалом. Обидва типи змагань були запроваджені в другій половині XX ст. 3 різницею у приблизно 20 років. Параолімпійські ігри, як і Юнацькі, проводяться, як взимку так і влітку, у роки Зимових чи Літніх Олімпійських ігор. Всесвітні ж ігри проводять тільки під час календарного літа, раз на чотири роки, за рік після проведення Літніх Олімпійських ігор. Також Ігри відрізняються тим, що Параолімпійські ігри проводяться на підготовлених до Олімпіад об'єктах, а організатори Всесвітніх та Юнацьких ігор мають повністю розбудовувати нову інфраструктуру та спортивні об'єкти. Всесвітні ігри зазвичай проводяться в нерозпіареному у світовій спільноті місті, в той час, як Параолімпіади вслід за Олімпійськими іграми проходять у найвідоміших містах світу. Спільною рисою Всесвітніх, Паралімпійських та Юнацьких Олімпійських ігор є відносна мала відвідуваність, хоча й Параолімпіади помітно виграють у Всесвітніх Ігор за цим показником. Також обидва типи спортивних подій помітно додають у свої популярності, перманентно збільшуючи кількість глядачів на своїх заходах. Це є наслідком наступної спільної риси - відповідність світовим тенденціям, що дає змогу перехопити на себе увагу медіа та усієї світової спільноти. Особливо це стосується молоді.

Отож, у підсумку можна сказати, що проведення Олімпійських ігор не $\epsilon$ гарантією стрімкого розвитку туризму. Для того, щоб вони мали позитивний вплив на туризм, потрібно врахувати багато факторів і забезпечити ефективну організацію.

\section{Список використаних джерел та літератури:}

1. Athens 2004 Olympic Games. URL: https://www.britannica. com/ event/Athens-2004-Olympic-Games

2. BEIJING 2008. URL: https://www.olympic.org/beijing-2008

3. Rio 2016 price tag rises to $\$ 13.2$ billion URL: https://www.reuters. com/article/us-olympics-brazil-cost/rio-2016-price-tag-rises-to-13-2-billionidUSKBN19539C

4. Ruin of Olympics. URL: http://rendezvous.blogs.nytimes. com/2012/07/15/ruin-porn-the-aftermath-of-the-beijing-olympics/

5. The World Games. URL: https://www.theworldgames.org/

6. WHAT IS YOG? URL: https://www.olympic.org/news/what-is-yog

7. Лондонська олімпіада окупилась через рік. URL: https:// www. ukrinform.ua/rubric-sports/1521524-londonska_olimpiada_okupilasya cherez_rik_1846465.html

Олександра Печерська,

студентка 4 курсу

Національний університет «Острозька академія»

\section{ТЕНАЕНЦІЇ РОЗВИТКУ ФЕШН-ТУРИЗМУ В XXI CTOЛITTI}

3 XXI століття розпочинається стрімке збільшення популярності фешн-туризму і переосмислення ролі Тижнів моди, вони стають головними подіями індустрії моди на міжнародному ринку зі стабільним графіком проведення. Основними центрами туризму у рамках річного циклу Тижнів моди стали Нью-Йорк, Лондон, Мілан і Париж, так звана «Велика четвірка». Помітними, крім «Великої четвірки», в останні роки стали покази у Сеулі, Копенгагені, Бейруті, Гонконзі, Токіо, Тбілісі, Києві, Лос-Анджелесі, Дубаї, Москві, Сіднеї, Берліні, Сан-Паулу, Римі, Монако, Шанхаї, Мадриді, Ванкувері, Джакарті, Нью-Делі, Аммані. Поступово стираються межі сезонності внаслідок збільшення мобільності населення та відчутного зростання швидкості передавання інформації. А на показах 3 2018 року дизайнери Том Форд і Томас Барбері порушили класичне правило сезонів, не чекали пів року та запустили формат «Дивись та купуй вже зараз», продаючи свої колекції одразу після демонстрації. Цю тенденцію швидко підхоплюють й інші Будинки моди та дизайнери.

У XXI столітті, поряд із професіями, що вже традиційно стали безпосередньо пов'язаними 3 проведенням показів (дизайнери, модельєри, стилісти, візажисти, моделі, закрійники одягу, швачки), зростає роль колористів, креативних директорів, продюсерів, торгових агентів, кастинг-директорів, піар-агентів та працівників рекламної сфери, IT спеціалістів, маркетологів, контент-менеджерів, дистриб'юторів, логістів, івент-агентів, режисерів-постановників, аудіо-, відео режисерів, кухарів для харчування учасників шоу за лаштунками.

Мода почала реагувати на суспільні зміни та навіть сама формувати ці зміни. На міжнародних подіумах стираються расові, вікові, гендерні обмеження, частіше запрошують моделей різних вагових категорій, змінились вимоги до модельних стандартів. Різноманіт-

(с) Олександра Печерська, 2020 
ність та відмінність стали нормою, що вивело Тижні моди у наступне покоління. Осінь 2017 року стала першим сезоном, коли під час кожного показу на подіум виходила як мінімум одна модель не європеоїдної раси. Сезон весна/літо 2018 побив усі попередні рекорди: на 266 основних показах у чотирьох столицях моди понад $30 \%$ моделей були негроїдної, австралоїдної або азійської раси. Лідером у цьому русі був Нью-Йорк (36,9\% моделей), за ним слідує Лондон (31\%) і Париж (27\%). Найбільш консервативним залишились представники Мілану $(24,7 \%)$, хоча і на місцевих показах показник зріс з 2015 року на 9\%. Найбільш расової збалансованості дотримуються такі будинки: «Kenzo», «Sophia Webster», «Ashish», «Chromat», «Tome».

3 огляду на поступове розширення критеріїв щодо параметрів моделей і світове зростання попиту на одяг більших розмірів, на подіум все частіше виходять представниці Plus-Size. Однією із натхненниць руху та найвидатніших моделей Plus-Size $\epsilon$ Меліса Аронсон, яка увійшла у 1994 році до рейтингу «50 найкрасивіших людей» журналу «Реople» 3 вагою 86 кг та стала однією з найбільш високооплачуваних моделей цієї категорії у 90-их роках ХХ століття. Також впливовими моделями з вагою 80-100 кг стали Інга Ейріксдоттір, Ешлі Грехем, Хейлі Гермс, Тара Лінн, Робін Лоулі, Бішамбер Дас, Кендіс Хаффін. Окрім участі в показах, ці моделі є творцями власних ліній спідньої білизни та спортивного одягу для жінок із розміром одягу від 42 до 54, пишуть статті у провідні видання, виступають з власною позицією на публіці, беруть участь у проєктах щодо захисту жінок від насилля, ініціюють створення психологічних центрів.

Частіше учасницями Тижнів моди стають maternity models, які успішно увійшли на ринок одягу для вагітних. Зокрема, у НьюЙорку у 2018 році дефілювала жінка на сьомому місяці вагітності. На подіуми Тижнів моди частіше запрошують моделей старшого віку. Зокрема, восени 2017 року 21 модель була старше 50-и років, а у 2018 - 27 осіб (з них 10 на подіумах Нью-Йорка, 7 - Мілана, 7 Парижа, 3 - Лондона). Серед таких моделей у 2018 році виділялись Коко Мітчелл («Тоте»), Сьюзан Ціансіоло («Eckhaus Latta»), Софія Ламар («Helmut Lang») та Емма («Chromat»). Для них індивідуально формують план харчування, фізичних вправ та догляду, за станом здоров’ я постійно слідкують лікарі.

В рамках привернення уваги до кліматичних змін, 3 ініціативи захисниці прав тварин Емманюель Рієнда, у жовтні 2018 року в Каліфорнійському ринковому центрі було проведено всесвітню кон- ференцію «Майбутнє моди», де в ході дискусії підіймались питання клімату та моди, були представлені інновації, які не шкодять тваринному світові, а також пройшли покази за стандартами веганських норм, зокрема японського бренду Енда. У лютому 2019 року вперше світ побачив Веганський Тиждень моди, який пройшов у ЛосАнджелесі. Темою весняного сезону стала «Мода - це активізм», де продовжується рух щодо розв'язання проблем кліматичних та екологічних змін задля завершення ери нещадної експлуатації тваринного світу. Під егідою руху animal friendly та fur free бренди масово відмовляються від використання натурального хутра. Зокрема, одним із натхненників став бренд «Calvin Klein», що зробив цей крок у 1994 році, бренд «Stella McCartney» відмовився від хутра і шкіри у 2001 році. «Ralph Lauren» у 2006 році зупинив виробництво одягу iз хутра, а свою попередню колекцію в кількості 1200 одиниць передав на благодійність. Бренд «Vivienne Westwood» також з 2006 року відмовився від хутра, і сумки з натурального хутра кролика віддали до заповідника живої природи. Це питання особливо часто почали підіймати у 2010-их роках. До попередніх брендів приєднались i «Tommy Hilfiger» (2007), «Hugo Boss» (2015), «Armani» (2016), «Michael Kors», «Gucci», (2017), «Versace», «Chanel», «Burberry», «Jean Paul Gaultier» (2018), «Coach», «DKNY» (2019). Про відмову до 2020 року заявили й в Prada, щоб до того часу розпродати уже створену продукцію. Лондонський Тиждень моди вже повністю заборонив покази із використанням натурального хутра.

Отже, у XXI столітті Тижні моди переходять на якісно новий рівень організації, вони наповненні видовищами, мають продуману концепцію, залучають до роботи спеціалістів різноманітних профілів. Приваблюючи увагу масштабним шоу Тижні моди формують ставлення громадськості до нових модних течій, а також важливих соціальних тем як дискримінація за расовими, віковими, гендерними, зовнішніми характеристиками, збереження природи, зменшення шкідливих викидів у навколишнє середовище. Крім чотирьох світових столиць мод до створення яскравого шоу приєднуються десятки інших міст по всьому світу.

\section{Список використаних джерел та літератури:}

1. 150 модных брендов снизят негативное воздействие на окружающую среду. URL: https://vogue.ua/article/fashion/brend/32modnyh-kompanii-poobeshchali-snizit-negativnoe-vozdeystvie-naokruzhayushchuyu-sredu.html 
2. 3 Ways NY Fashion Week Is Redefining Beauty Standards. URL https://www.leaf.tv/10852484/3-ways-ny-fashion-week-is-redefiningbeauty-standards/

3. 9 Curvy Models Taking the Modeling Industry by Storm. URL: https:// www.thebalancecareers.com/curvy-models-taking-industry-4034144

4. Fashion Week Schedules, History and Facts. URL: https://glowsly. com/fashion-week-schedules-history/

5. For the first time, every NYFW catwalk had a model of colour. URL: https://www.harpersbazaar.com/uk/fashion/shows-trends/news/a40097/newyork-fashion-week-autumn-winter-2017-diversity-report/

6. Landmark Gains for Nonwhite, Transgender and Plus-Size Models on the Spring 2018 Runways. URL: https://www.thefashionspot.com/runwaynews/768143-runway-diversity-report-spring-2018/

7. The Big 4 Fashion Capitals. URL: https://www.zayahworld.com/ seasons-in-fashion-industry-year

8. Top 31 Plus-Size Models of All Time. URL: https://glowsly.com/topplus-size-models/

\section{Олександра Фомін,}

студентка 4 курсу

Начіональний університет «Острозька академія»

\section{РЕАІГІЙНИЙ ТУРИЗМ В ОАЕ В ХХІ СТОАІТТІ: ПРОБЛЕМИ ТА ПЕРСПЕКТИВИ}

Релігійний туризм, як галузь, виник у XIX столітті. В цей період він закріпився в ряді туристичних напрямків країн світу. Відвідування культових споруд різних конфесій, чи участь у релігійному святі не завжди вказують на те, що людина належить то тієї чи іншої конфесії. Багато людей обирають релігійний туризм, подорожуючи групами або індивідуально, маючи за мету не тільки паломницькі та місіонерські цілі, а й проведення власного дозвілля чи наукового дослідження. Тим не менше, релігійний туризм є однією з найбільш високодохідних галузей туризму країн. Иого значення, як джерела фінансових та валютних інвестицій, важливо та необхідно дослідити, адже середньостатичний турист витрачає близько 600 доларів на день в тому чи іншому місці відпочинку. На сьогодні, Об'єднані Арабські Емірати входять в число країн-лідерів Близького Сходу в сфері релігійного туризму, що окреслює динаміку економічного зростання країни.

Вагомий внесок у наукове вивчення релігійного туризму здійснили Арті Саундалкар, Амна Етешам Хайшгі, Ісмаіл Себугваво, Йоанна Андрювс, Маріо Манічуло та інші науковці. Зокрема, дослідження цього виду туризму базується на комплексному аналізі окресленні подальшої динаміки його розвитку. Позитивно оцінюючи внесок згаданих вчених у розробку проблеми варто зауважити, що існує низка недосліджених питань. Більш детального вивчення потребує таке нове явище для країни, як ліцензування храмів, програма «Рік толерантності», проведення релігійних конференцій, форумів світового рівня, а також збільшення конкурентоспроможності ОАЕ серед регіонів світу, де релігійний туризм складає третю частину від загального доходу туризму. 3 огляду на це тема без сумніву $\epsilon$ актуальною.

Близький Схід уже багато століть $є$ «найбільшим локомотивом світу в напрямку релігійних подорожей, туризму та гостинності»,

(C) Олександра Фомін, 2020 
як відзначив Кевін Райт, президент Всесвітньої асоціації релігійних подорожей (WRTA). У 2019 році OAE розпочали робити значні кроки для збільшення кількості туристів різних конфесій, тим самим розвиваючи релігійний туризм, який тільки в регіоні Близького Сходу приносить більше 18 мільярдів доларів щорічно, що на 8 \% більше у порівнянні з Державою Ізраїль, де найбільший показник прибутку від цього виду туризму був зафіксований у 2019 році - 9,7 млрд доларів.

Варто відзначити і розвиток інфраструктури релігійного туризму в ОАЕ. Зокрема, на початку 2019 року було відкрито тематичний Парк Корані, що розташований в Аль-Хаванеї, де відвідувачам пропонується поглибити власні уявлення про Священний Коран. Найвідомішим місцем серед туристів, які обирають релігійний туризм, як відпочинок, в ОАЕ є Велика мечеть шейха Заїда в Абу-Дабі, яку в 2017 році відвідало майже 5,8 мільйонів туристів - порівняно 3 2014 роком, коли відвідувачів було в 3 рази менше. 3 кожним роком кількість туристів до цієї культової пам'ятки зростає на 1,5\%. Саме ця мечеть $€$ улюбленим місцем і серед світових знаменитостей, громадських діячів: співачка Ріанна, чемпіон Формули-1 Льюїс Гамільтон та королева Єлизавета II. Тим не менше, в ОАЕ можна знайти місця поклоніння будь-якого віросповідання, що служать не тільки місцем уособлення віри, але і культурно-історичною спадщиною, витвором мистецтва та архітектури. Одним із яскравих прикладів $\epsilon$ сикхський храм - Гурдвара. Важливе значення для розширення не тільки туристичної інфраструктури, але і для розвитку релігійного туризму відіграє Ехро 2020. Адже розширення роздрібної торгівлі, нові проекти та розвиток транспортних шляхів, залучення туристів різних релігій світу, відкриє більший ринок послуг і товарів. Все це буде досягнуто завдяки підготовці до проведення цього заходу світового масштабу.

Також, 2019 рік був визначений «Роком толерантності» у країні. Член Департаменту туризму ОАЕ, Сурендер Сингх Кандхарі заявив, що країна $\epsilon$ «живим прикладом толерантності, мостом між народами різних культур у шанобливому середовищі, яке відкидає екстремізм та наголошує на прийнятті інших». Це підтверджує те, що країна відкрита для туристів різних релігій та переконує, що державний апарат поступово трансформує країну для мультикульрного населення. Така заява одного із співробітників Департаменту туризму створює відчуття безпеки для туристів у мусульманській країні. Також, для підтримання відповідних цінностей «Року толерантності» було, запущено програму «The Mosques Tour Initiative» у рамках міжконфесійного партнерства, яку започаткував Департамент культурного туризму при Генеральній владі у справах ісламу та фондів церков, з ініціативи святих отців християнських церков Андерсона Томпсона та Фахро, виконавчого директора 3 питань ісламу Омара Харбтора Аль Дарей. Ця програма передбачала безкоштовні екскурсії значущими культовими місцями: мечеті Шейх Султан бін Заїд, Аль Карім в Аль-Марині, Аль-Азіз на острові Рем, Шейх Заїд бен Султан, Друга мечеть в Аль-Халідії, Мечеть Маріам та Умм Ейза в Аль-Мушріф. Під час екскурсійних турів всі гості країни мали можливість ознайомитися з етикетом відвідування мечетей, їх роллю в ісламському суспільстві та історичними фактами про релігійне значення цих культових місць.

Тим не менше, на початку 2019 року було переглянуто законодавство ОАЕ, під гаслом «Заклик до гармонії». Ключове рішення полягало в тому, щоб об'єднати всі заклади багатьох віровчень під однією ліцензією. Іншими словами, такі заклади, як храми, церкви та гурудвари для сикхів почало регулювати DCD (Департамент розвитку громади). Раніше згадані місця культу не були визнані законодавством ОАЕ. Основною метою такого кроку з боку уряду країни $\epsilon$ «надання офіційного єдиного каналу в уряді для релігійних органів, щоб ліцензовані культові місця звертатися за спеціальними проханнями та коли їм необхідна підтримка, чи допомога», прокоментував цю ініціативу Султана аль-Дхахері, виконавчий директор із питань громадської діяльності та спорту при DCD. Також, ще у 2012 році відбулося дарування земельних ділянок для сикхів, призначених під будівництва їх храмів. Що стосується християнських храмів, то в 2019 році запущено програму будівництва 19 немусульманських культових місць для громад, які проживають в Абу-Дабі, з яких 17 - це церкви та каплички. Така політико-правова ініціатива була запущена в дію задля контролю державою всіх релігійних установ у країні, щоб убезпечити населення ОАЕ від релігійно-культурних конфліктів. Таким чином, держава підтримуватиме, регулюватиме дії багатьох конфесій, які мають власні храми, церкви на території країни.

Зібраний і проаналізований фактичний матеріал дозволяє проілюструвати проблеми та перспективи розвитку релігійного туризму в ОАЕ. Так, важливою проблемою сучасності $є$ політично нестабільний регіон, що спричиняє загрозу безпеці туристів, які зацікавленні у відпочинку в Еміратах. Цей фактор змушує гостів країни вибирати інші, більш стабільні регіони для відпочинку. До числа проблем можна віднести і забезпечення спеціалізованим персона- 
лом інфраструктурні комплекси та культові місця для обслуговування представників тих чи інших релігій, підготовка якого потребує відповідних коштів і навичок професійної діяльності. Таким чином, забезпечення належного обслуговування на базі інфраструктурного комплексу чи центру проведення культових заходів часто переходить понад дозволені рамки бюджету, передбаченого заздалегідь на організацію події, створює проблему для подальшого фінансування всієї галузі туризму.

Що стосується перспектив розвитку цього виду туризму, то дослідивши статистичні дані стає зрозуміло, що загальна кількість подорожей $з$ релігійною метою залишається незмінною. Проте, в Об'єднаних Арабських Еміратах кількість туристів, які здійснювали подорож до країни з культурно-пізнавальною метою, що включає і ознайомлення 3 релігійними пам'ятками та особливостями країни, зросла до 16,66 млн закордонних відвідувачів в 2019 році, це на 2,9\% більше в порівнянні з 2018 роком. Тим не менше, разом 3 туристами, практикуючі багатьох конфесій приносять значний дохід в економіку ОАЕ, через відсотковий податок від загальної суми на послуги чи товари, які вони обирають включно 3 відпочинком на базі туристичних комплексів. Так, в середньому податок на продукти харчування складає 2-5\% від ціни товару, а на оренду житла чи машини - 15-20\%. Цей факт підтверджує те, що бюджет держави збільшується від кожної плати туристом за товар чи послугу в країні.

Отже, основні аспекти релігійного туризму - культурний відпочинок, наукове дослідження, різного роду конфесійні конференції, форуми, конгреси, ініціативи мають переваги у вигляді розробки різноманітних туристичних програм. Під час дослідження було розглянуто проблеми розвитку цієї галузі туризму в країні - нестабільна політична ситуація на Близькому Сході та нестача професійних кадрів для обслуговування туристів різних конфесій.

\section{Список використаних джерел:}

1. 300m Religious Tourists in Middle East p.a. Financial Tribune. 2014 URL: https://financialtribune.com/articles/travel/5492/300m-religioustourists-in-middle-east-pa

2. Abu Dhabi Hotel Performance Report Q3 2019. Department of culture and tourism. 2019. URL: https://tcaabudhabi.ae/DataFolder/reports/hotelestablishment/2019/Abu-Dhabi-Hotel-Performance-Q3-2019-English.pdf

3. Dubai Tourism Statistics 2019. Global Media Insight. 2019. URL https://www.globalmediainsight.com/blog/dubai-tourism-statistics/
4. Dubai's economy grew $2.1 \%$ in first half of 2019. Gulf News Web Report. 2019. URL: https://gulfnews.com/uae/government/dubais-economygrew-21-in-first-half-of-2019-1.1574618428492

5. Mario Masciullo. Christian tourists to have 17 more places of worship to see in UAE. eTN Italy. 2019. URL: https://www.eturbonews.com/256959/ christian-tourists-to-have-17-more-places-of-worship-to-see-in-uae/

6. Початок Рамадану: Питання та відповіді про священний для мусульман місяць. 112. ua. 2019. URL: https://ua.112.ua/golovni-novyni/ pochatok-ramadanu-pytannia-ta-vidpovidi-pro-sviashchennyi-misiats-dliamusulman-490652.html

7. Рамадан в 2020 году: начало и конец поста. 2020. URL: https:// www.kp.ru/putevoditel/kalendar-prazdnikov/ramadan/ 


\section{Олена Герасимчук,}

студентка 4 курсу

Національний університет «Острозька академія»

\section{ТЕМАТИЧНІ ПАРКИ КУРОРТУ TOKYO DISNEY RESORT}

Транснаціональна компанія Disney керує курортами, що поділяються на тематичні парки в багатьох країнах світу. Кожен парк має свою особливу структуру з безліччю атракціонів. Зазвичай у них тематично втілені медіафраншизи, якими володіє THK Disney. Тематичні парки користуються популярністю не лише у дітей, найбільше їх відвідують туристи віком від 18 до 39 років. Tokyo Disney Resort розташований в Ураясу, Тіба, Японія. Курорт поділяється на два тематичні парки: Tokyo Disneyland та Tokyo DisneySea. A також окремо виділяють торгово-розважальний комплекс 3 великим фудкортом Ikspiari. Кожен парк поділяється на певну кількість тематичних земель, що, в свою чергу, містять магазини, заклади харчування, готелі та інші атракціони.

Тематичний парк Tokyo Disneyland займає площу 47 га. Він поділяється на шість тематичних земель. П'ять 3 них традиційні для Діснейлендів: Adventureland, Westernland, World Bazaar, Fantasyland i Tomorrowland, а також дві міні-землі: Critter Country та Mickey’s Toontown.

Тематична земля World Bazaar є пропускним пунктом до інших областей. World Bazaar-це основна торгова зона в Tokyo Disneyland, вона складається 3 двох вулиць Main Street та Center Street. Ця тематична земля містить постійний навіс, у вікторіанському стилі, що охоплює райони цих двох вулиць. Найпопулярнішими атракціонами тут $є$ Omnibus, оскільки він переміщується територією всієї тематичної землі, що дозволяє побачити всі визначні пам'ятки з сидіння омнібусу.

Тематична земля Adventureland поділяється на дві взаємозалежні області в тематиці Нового-Орлеану та джунглів. Тут розташований унікальний атракціон Western River Railroad. Також до популярних пам'яток відносяться Jungle Cruise та Pirates of the Caribbean. Це два атракціони типу dark ride. Перший з них популярний тим, що в оформленні використані роботизовані макети тварин в повному їх розмірі. Другий з них популярний, завдяки тому, що в цьому атракціоні втілено відому кінофраншизу «Пірати Карибського моря».

Westernland - це тематична земля, побудована в стилі вестерну. Найбільш відомими атракціонами $є$ Big Thunder Mountain та The Diamond Horseshoe. Перший 3 них популярний, тому що це найвищі гірки в парку. Атракціон The Diamond Horseshoe це театр-ресторан, гості якого можуть скуштувати японську кухню та подивитися виставу.

Fantasyland містить майже точну копію замку Попелюшки, що знаходиться у Флоридському Діснейленді. Найпопулярнішими атракціонами є Alice's Tea Party, Cinderella Castle та Cinderella's Fairy Tale Hall, тому що в них втілено кінофраншизи компанії, такі як «Аліса в Країні чудес» та «Попелюшка». Cinderella Castle користується популярністю також, тому що розташований в найвищому місці тематичної землі.

Тематична земля Tomorrowland побудована у стилі ретрофутуризму. Серед визначних пам'яток, найвідомішими є Space Mountain та Star Jets, а також Pan Galactic Pizza Port, ресторан, який містить велику аудіо-аніматронічну машину для виготовлення піци. А Critter Country - це невелика територія парку, в якій міститься визначна пам'ятка, гора Splash. Єдиний атракціон, який тут знаходиться Beaver Brothers Explorer Canoes.

Mickey's Toontown - це тематична земля, що є дзеркальним відображенням такої ж області у Флоридському Діснейленді. Найбільш популярною пам'яткою тут $є$ Chip 'n Dale's Treehouse. Вона $є$ точною копією будинку з мультфільму «Чіп і Дейл спішать на допомогу».

Другий парк має назву Tokyo DisneySea. Його площа становить 71,22 га. Він поділяється на сім тематичних земель, або ж як їх ще називають сім морських тематичних портів: Mediterranean Harbor, American Waterfront, Lost River Delta, Port Discovery, Mermaid Lagoon, Arabian Coast i Mysterious Island. Цей парк має загальну морську тематику. Входом до Tokyo DisneySea служить тематична земля Mediterranean Harbor. Вона оформлена в стилі італійського портового міста з венеційськими гондолами. У цій тематичній земл розташована велика кількість ресторанів та магазинів. Найпопулярнішим атракціонам $є$ нічне шоу «Fantasmic!» у ньому використовуються феєрверки, лазери, водні ефекти, піротехніка, музика, аудіоаніматроніка, прожектори та проекції туману, що приваблює значну кількість туристів.

(C) Олена Герасимчук, 2020 
Mysterious Island - це тематична земля на горі Прометей, що являє собою вулкан, який є центральною частиною парку і найпопулярнішою визначною пам'яткою. Він заснований на розповідях Жуля Верна та міфології з серії книг «Вулканія». Ця тематична земля побудована у вікторіанському стилі і $є$ найменшою в парку.

Тематичний порт Mermaid Lagoon - це місце в якому розташовуються герої франшизи «Русалонька». Ця тематична земля здебільшого знаходиться в приміщенні, щоб створити відчуття перебування під водою. В Mermaid Lagoon розташовані такі атракціони як Flounder's Flying Fish Coaster, Scuttle's Scooters, Jumpin' Jellyfish, Ariel's Playground, а також The Mermaid Lagoon Theater, де проходить музичне шоу, що демонструє історію русалки Аріель.

Arabian Coast - це тематична земля, що відтворює арабську гавань у поєднанні з реалізацією світу з франшизи «1001 Arabian Nights». Вона містить 4 пам'ятки Sindbad's Storybook Voyage, Caravan Carousel та карусель Jasmine's Flying Carpets i The Magic Lamp Theater, де проводиться шоу з використанням 3-D анімації.

Тематичний порт Lost River Delta розташовується у віддаленій частині парку. У ньому знаходяться руїни старовинної піраміди ацтеків, в якій розташований найпопулярніший атракціон dark ride під назвою Indiana Jones Adventure: Temple of the Crystal Skull.

Port Discovery - це тематична земля в стилі ретрофутуризму. В ній розташований популярний ресторан Horizon Bay. Port Discovery містить два атракціони: Aquatopia, що являє собою прогулянку на човні, а також вузькоколійка DisneySea Electric Railway, що перевозить туристів до наступного тематичного порту.

Тематична земля American Waterfront поділяється додатково на дві тематичні області Old Cape Cod та New York Harbor. Основними пам'ятками є Tower of Terror, Turtle Talk та Toy Story Mania! Також у цій тематичній землі зосереджена велика кількість ресторанів, кав'ярень та їдальнь.

Tokyo Disneyland та Tokyo DisneySea займають третє та четверте місце в світі за відвідуваністю в 2018 році, із кількістю туристів 17 907000 та 14651000 відповідно. Показники зросли приблизно на 7\% у порівнянні з попереднім роком. Найбільш відвідуваним парком в Tokyo Disney Resort $\epsilon$ Tokyo Disneyland. Щодня його відвідують в середньому 37064 туристи. У середньому кожен відвідувач витрачає в парку 11820 єн, без ПДВ. На відвідуваність курорту в Японії впливає велика кількість факторів і головним з них є природні умови, що змушують Діснейленд працювати відповідно до обставин. Основна проблема парків Tokyo Disneyland та Tokyo DisneySea полягає в тому, що попит перевищує пропозицію. Транснаціональна компанія Disney намагається боротись 3 цим шляхом розширення території парку, проте це не усуває проблему повністю. Популярні тематичні землі так і залишаються надто завантаженими, а нові не завжди стають популярними і з часом змушені закриватися.

На ринку індустрії розваг у ТНК Disney основними конкурентами є Merlin Entertainments Group та Universal Parks and Resorts. Остання 3 них також втілює франшизи власних фільмів у своїх тематичних парках. ТНК Disney модернізує старі атракціони та будує нові задля утримання провідних позицій. Проте така діяльність не завжди є ефективною. Наприклад, тематична земля Glacier Bay після відкриття не набула популярності серед відвідувачів і керівництвом компанії. було прийняте рішення закрити ії на реконструкцію. Згодом було вирішено відкрити нову тематичну зону з втіленням франшизи THK Disney «Історія іграшок», оскільки цей мультфільм набув великої популярності серед японської аудиторії в 2010 році.

Ще однією проблемою в розвитку тематичних парків компанії в Японії є нерівномірність туристичних потоків. Наприклад, основними туристичними потоками Tokyo Disney Resort $\epsilon$ внутрішні туристи Японії, та незначна частка з сусідніх країн, таких як Південна Корея та Китай. Основною віковою категорією, що відвідують Tokyo Disney Resort є діти віком від 12 до 17 років. Проте зважаючи на особливості національної системи освіти, тривалість навчального року в школярів становить 240 днів на рік, що обмежує можливість відвідування тематичних парків цією віковою категорією.

Отже, тематичні парки курорту Tokyo Disney Resort мають особливу інфраструктуру. Tokyo DisneySea $\epsilon$ унікальним парком і не має аналогів в інших курортах THK Disney. Найбільшою популярністю користуються вони в туристів віком від 18 до 39 років. Tokyo Disneyland знаходиться на другому місці за кількістю відвідувачів в світі. Відповідно до популярності певних атракціонів та появи нових франшиз ТHК Disney відкриває нові, або замінює старі тематичні зони та розважальні майданчики. Тематичні парки ТНК Disney $\epsilon$ дуже перспективним напрямком розвитку туристичної галузі та відіграють важливу роль в туристичній привабливості Японії.

\section{Список використаних джерел та літератури:}

1. Breakdown of guests at Tokyo Disneyland and DisneySea theme parks in Japan in fiscal year 2018, by age group. URL: https://www.statista. com/statistics/996957/guests-age-distribution-tokyo-disneyland-disneyseatheme-park/ 
2. Combined attendance at Tokyo Disneyland and DisneySea theme parks in Japan from fiscal year 2009 to 2018. URL: https://www.statista.com/ statistics/996751/japan-combined-attendance-tokyo-disneyland-disneyseatheme-park/

3. Corporate Social Responsibility Update 2017. URL: https:// thewaltdisneycompany.com/app/uploads/2017disneycsrupdate.pdf

4. Disney Enterprises Inc. Annual Report. URL: http://www.secinfo.com/ dsvRs.bq.htm

5. Disneyland Expansion Plan: What happened to «Glacier Bay»? URL: https://disneyandmore.blogspot.com/2009/07/hong-kong-disneylandexpansion-plan.html

6. The Walt Disney Company Reports Fourth Quarter and Full Year Earnings for Fiscal 2019. URL: https://www.thewaltdisneycompany.com/ the-walt-disney-company-reports-fourth-quarter-and-full-year-earnings-forfiscal-2019/

7. Theme index. Museum Index 2018. URL: https://www.aecom.com/ wp-content/uploads/2019/05/Theme-Index-2018-4.pdf

8. World's most popular theme parks. URL: https://edition.cnn.com/ travel/article/most-popular-theme-parks-world-2018/index.html

\section{Олена Контаріз,}

студентка 4 курсу

Начіональнии університет «Острозька академія»

\section{ПРОБАЕМИ І ПЕРСПЕКТИВИ РОЗВИТКУ ТУРИЗМУ У ФІНАЯНАІї}

Фінляндія - це країна, яка володіє великим національним, природним і духовним надбанням. За останні роки країна перетворилась на одного з лідерів туристичного бізнесу в Свропі. Державна політика щодо впровадження сталого розвиту туристичної галузі та турбота про високий рівень життя принесла позитивний результат - у секторі туризму зайнято близько 150 тис. чоловік. Це складає приблизно 4 млрд. євро податкових надходжень на рік і становить понад 4\% ВВП [8].

Своєрідним каталізатором розвитку туризму в Фінляндії виступає уряд країни. Починаючи з 2004 року, він витрачає більше 260 млн євро на розвиток туристичної індустрії. Значна частина цих коштів спрямовується на рекламу Фінляндії, як туристичного напрямку в багатьох країнах світу. У 2005 році Фінський уряд прийняв рішення провести ряд заходів, спрямованих на експорт фінської культури, однією з форм якого виступає розвиток культурного туризму [6].

Туризм надає величезний мультиплікативний ефект на економічну активність в різних областях Фінляндії і $\epsilon$ великою галуззю промисловості. У цілому є більше 150000 працівників по найму. Тобто, більше 5\% зайнятого населення Фінляндії заробляє на життя в різних секторах туризму. Понад однієї десятої робочого населення зайнято в секторах приватних послуг туристичного бізнесу. Джерелом майже 5\% державних податків і податкових платежів індустрія туризму [7].

Варто зазначити, що у Фінляндії економічний вплив туризму безперервно підвищується. Успіх в туризмі врівноважує регіональний розвиток, так як багато ключових туристичних баз відпочинку і туристичних підприємств розташовані за межами центрів зростання. Туристичні послуги або додатковий попит сприяють наданню більш різноманітних і якісних послуг для місцевих жителів і створюють 
основну інфраструктуру, забезпечуючи основу для розвитку інших форм підприємницької діяльності $[3,132]$.

У Стратегії туризму Фінляндії до 2020 р. викладена політика вкладу державного сектора на підтримку туризму. У ній визначені основні цілі розвитку, перераховані заходи для досягнення цих цілей і описані кроки, необхідні для відстеження ефективності проведених заходів [5, 78].

Що стосується цін на фінські туристичні послуги, то у європейському масштабі вони $є$ високими через високі податки і трудовитрати. Згідно зі Стратегією пропонується утримати ПДВ на конкурентоспроможному рівні в європейському масштабі, а податок на електрику в сфері послуг знизити до рівня, який застосовується в промисловості.

Вирішальне значення для туризму має доступність. У зв'язку з цим Стратегія пропонує, щоб залізничне сполучення було збільшено за рахунок модернізації вокзалів у Гельсінкі і Тіккуріли. Крім того, в ній запропоновані термінові субсидії для збільшення обсягів чартерних рейсів і сприяння відкриттю нових маршрутів польоту.

Літні канікули у Фінляндії не заплановані на однаковий час з рештою частиною Європи. Стратегія передбачає, що літні канікули в школах і інших навчальних закладах будуть відкладені на два тижні, а зимові канікули будуть розподілені більш рівномірно в лютомуберезні протягом 7-11 тижнів.

Також, згідно зі Стратегією, заходи, які спрямовані на розвиток туризму, повинні грунтуватися на перевірених сильних і слабких сторонах Фінляндії і привести в кінченому підсумку до потреб розвитку. Головні конкуренти Фінляндії на міжнародному ринку туризму - Швеція і Норвегія. Таким чином, iї сильні і слабкі сторони також розглядаються щодо цих країн.

Щодо сильних сторін фінського туризму, то вони включають в себе унікальне розташування, привабливі зони відпочинку-туризму, а також різноманітні послуги.

Слабкими ж сторонами туризму в Фінляндії є поінформованість про країну, ії доступність для туристів, високий рівень цін, недостатня кількість націлених на роботу іммігрантів та велика кількість зон, де туризм має сезонний характер.

Оперативні передумови туристичного бізнесу можуть бути поліпшені шляхом заохочення інвестицій в інфраструктурні зони туризму, що не будуть спотворювати конкуренцію між підприємствами. Ці заходи підвищать цінність бренду Фінляндії і зроблять країну більш привабливим і популярним місцем для туристів.
Перспективним напрямком розвитку туризму у Фінляндії може стати екологічний та культурний туризм. Також, країні слід подумати про інформаційне забезпечення для кращого просування свого туристичного товару на міжнародний ринок.

Фінляндія реалізувала ряд нових стратегій і проектів, таких як перерозподіл стратегії біо-економіки, екологічно шкідливих субсидій, стимулювання продажу еко-інновацій всіх видів Tekes (Національне агентство за фінською технологією) проекту: розумне місто, розумний пошук, інновацій та технологій міста і Північного Льодовитого океану [1].

Що стосується еко-інновацій, то Фінляндія досягла інноваційної економіки, що характеризується високим рівнем продуктивності. Варто зазначити, для країни характерний високий обсяг інвестицій, що в загальному є вищим, ніж в країнах-членах ЄС. Наприклад, у Фінляндії на мільйон населення інвестують в зелені проекти 38,17 млн євро, в той час як в середньому по ЄС було тільки 12,3 млн євро [4]. Також, країна дотримується експортно-орієнтованої економіки, $65-90 \%$ експорту [2].

Таким чином, сучасна Фінляндія є одним 3 найперспективніших і найбільш екологічно чистих туристичних центрів у світі. В країні активно впроваджуються проекти, які сприяють розвитку сталого культурного туризму, зокрема, це інформаційний каталог про культурний туризм в центральній Фінляндії, проекти «Шлях в минуле» та «Метал в житті». Потужний потенціал має ідея розробки проекту «Культурна спадщина південного Саво». Тому можна стверджувати, що геополітичні та соціально-економічні умови є вкрай сприятливими для подальшого розвитку туризму в країні.

\section{Список використаних джерел та літератури:}

1. Макеева Д.Р. Зарубежный опыт формирования национальной системы качества туристских услуг: опыт Финляндии. URL: https://readera.org/zarubezhnyj-opyt-formirovanija-nacionalnoj-sistemykachestva-turistskih-uslug-14057780

2. Мировой атлас данных. Финляндия. URL: https://knoema.ru/atlas/ $\% \mathrm{D} 0 \% \mathrm{~A} 4 \% \mathrm{D} 0 \% \mathrm{~B} 8 \% \mathrm{D} 0 \% \mathrm{BD} \% \mathrm{D} 0 \% \mathrm{BB} \% \mathrm{D} 1 \% 8 \mathrm{~F} \% \mathrm{D} 0 \% \mathrm{BD} \% \mathrm{D} 0 \% \mathrm{~B} 4 \% \mathrm{D}$ $0 \% \mathrm{~B} 8 \% \mathrm{D} 1 \% 8 \mathrm{~F}$

3. Терес Н. Досвід Фінляндії з розвитку історико-культурного туризм. Етнічна історія народів Європи. 2018. Вип. 55. С. 130-135.

4. Туризм приносит Финляндии больший доход, чем лесная или пищевая промышленность. URL: http://fontankafi.ru/articles/32615/ 
5. Ягула К.П. Туристско-рекреационный потенциал Финляндии Демографические риски XXI века: материалы III Межвузовской студенческой конференции с международным участием, 13 мая 2016 г., Минск, Беларусь / БГУ, геогр. фак.; редкол.: Е.А. Антипова (гл. ред.). Минск: Белсэнс, 2016. С. 185-186.

6. Finlandas a tourist destination. URL:https://toolbox.finland.fi/lifesociety/finland-as-a-tourist-destination/

7. Industry Brief: Tourism. URL: https://www.lapland.fi/business/ tourism-industry-in-lapland/

8. Tourism in Finland stays on record level. URL: https://www. businessfinland.fi/en/whats-new /news/ 2019 /tourism-in-finland-stays-onrecord-level

\section{Яна Катрецька,}

студентка 4 курсу

Національний університет «Острозька академія»

\section{IPААНАСЬКІ ПИСЬМЕННИКИ ТА ЇХ ВНЕСОК У ЛІТЕРАТУРНІ АЕСТИНАЦІЇ ВЕАИКОБРИТАНІЇ}

Ірландія - це країна зі старовинною і багатою культурою, унікальними музичними та літературними традиціями. Туристи з усього світу з'їжджаються до Ірландії, щоб познайомитися з численними історичними пам'ятками цієї країни, надихнутися її мальовничими пейзажами і насолодитися веселими ірландськими святами.

Нині у всій світовій літературі не знайдеться аналога англо-ірландської літератури, назва якої викликає дискусій про те, кого до неї відносити. Якщо з авторами, які пишуть ірландською мовою все зрозуміло, то художня приналежність ірландців, які пишуть англійською мовою досить неоднозначна.

Проте, слід зазначити, що ірландські письменники відіграли важливу роль саме в літературі Великобританії - саме Ірландія подарувала багату культурну та літературну спадщину.

Дублін - особливе місце для любителів інтелектуальної літератури. Місто дало світові трьох лауреатів Нобелівської премії: Джорджа Бернарда Шоу, Семюела Беккета і Вільяма Батлера Йетса. У списку письменників світового значення, життя яких було пов'язане 3 ірландською столицею, значаться також Оскар Вайльд, Джеймс Джойс, Джонатан Свіфт і навіть Брем Стокер, автор «Дракули».

Дублінський музей письменників - це цілий будинок, розташований у центрі міста, призначений для того, щоб зберегти пам'ять про знаменитих ірландських авторів, у кожного з яких є одна згадка в резюме, яка їх об'єднує - час, проведений в Дубліні. Багато з них дійсно народилися в столиці Ірландії, а деякі поховані на дублінських кладовищах. Музей розділений на кілька поверхів - існує кімната, присвячена дитячій літературі, а також простір, який регулярно використовується для літературних читань [5].

У восьми милях від Дубліна знаходиться одна 3 важливих і цікавих пам’яток Ірландії - вежа Джеймса Джойса. Вона є музеєм,

(C) Яна Катрецька, 2020 
присвяченим пам'яті відомого письменника. Потрапивши сюди, ви зможете ближче ознайомитися з його життям і творчістю [10].

Справжня назва будови - вежа Мартелло, це своєрідний замокфорт, один $з$ побудованих на всій території Англії та Ірландії для оборони від наполеонівських військ. Свою назву вона отримала за назвою споруд на острові Корсика, де англійським солдатам випала можливість перевірити їй оборонну силу.

Першим, хто оселився в одному з фортів, став поет Олівер Гогарті. Це і послужило першою передумовою появи музею Джеймса Джойса, адже письменники за життя були друзями. У підсумку вежа, в якій оселився Гогарті, справила таке враження на Джойса, який пробув тут в гостях шість днів, що він описав ії в своєму романі «Улісс». Особливо докладно на сторінках була описана одна 3 кімнат. Зараз у цьому приміщенні повністю відтворений інтер'єр 3 роману. Втім, інші приміщення теж не пустують. Всі два поверхи займає чудова експозиція, що складається з фотографій, листів, автографів і особистих речей Джеймса Джойса. Тут зберігаються прижиттєві видання його творів, за які багато колекціонерів готові викласти круглу суму. До речі, на стіні одного з примішень ви знайдете невелику обпалену дірочку, що залишилася від пістолетного пострілу. Це пам'ять про одну зі сварок Гогарті і Джойса. Сьогодні, замок-форт $є$ пам'яткою Дубліна і одним з найпопулярніших музеїв столиці [7].

Роман «Улісс», який зачаровує своєю багатогранністю, а також за деякими версіями визнається кращим твором 20 ст., вивів Джойса на світову письменницьку арену. На батьківщину літератора, в Дублін, не перестають з'їжджатися шанувальники його таланту, а тому двері центру Джеймса Джойса, що на Норт Грейт Джордж-стріт, завжди відкриті для відвідувачів.

Будівля 3 червоного каменю, виконана в класичному георгіанському стилі, зберігає у своїх кімнатах меблі, якою за життя користувався письменник. Крім того, тут можна побачити предмети побуту і деякі особисті речі, що допоможуть оживити в уяві образ знаменитого автора. «Родзинкою» експозиції музею є справжні двеpi будинку, в якому проживав зі своєю невірною дружиною головний персонаж роману «Улісс» [12].

Невеликий, але дуже красивий, особливо у вогнях нічної ілюмінації, міст Джеймса Джойса став пам'яткою Дубліна відносно недавно. Урочисте відкриття об'єкта відбулося 16 червня 2003 р. Міст знаходиться в досить вузькому місці течії річки Ліффі. Завширшки міст має всього 33 м, але на цьому просторі вміщаються не тільки чотири смуги руху, а й дві пішохідні доріжки і місця для лавочок, 3 яких відкривається чудовий краєвид на річку [8].

Не випадково була обрана дата відкриття моста. Саме на 16 червня припадає святкування Дня Блума - присвяченого головному герою роману Джеймса Джойса «Улісс». У цей день в 1904 р. Стівен і Блум здійснили свою подорож по місту, маршрут якого повторюють сотні Дублінців і приїжджають на свято туристи. Влаштовуються масові читання роману і прогулянки по знайомих провулках [17].

3 ім'ям Джойса пов'язано ще одне знакове місце-будинок №15 по Ушерс Айленд, який виходить вікнами на міст, в ньому відбуваються головні події роману «Мертві» [11]

Джеймс Джойс стверджував, що за його романом «Улісс» можна буде відновити місто Дублін у разі руйнування, оскільки місце дій завжди вказано з великою точністю. По ірландській столиці можна гуляти не один день, проходячи «Улісса» розділ за розділом.

Екскурсію по Дубліну Джойс має сенс почати там, де починається дія великого роману. Стівен Дедал, Бик Малліган і Хейнс живуть в одній з сторожових веж Мартелло, які вже були згадані мною. Поруч 3 вежею розташований легендарний пляж, на якому бував сам Джойс, на ньому бували і його герої.

Маршрут «Каліпсо» - Екклс-стріт, будинок 7 - така адреса простого дублінця Леопольда Блума в «Уліссі». У житті це була адреса одного $з$ друзів Джойса. Саме $з$ цього будинку починається сучасна Одіссея Леопольда Блума. На жаль, оригінальна будівля знесена, як знесені і всі інші будинки на непарній стороні вулиці. Тепер на їх місці розташована лікарня. Бронзова плита на асфальті біля входу в неї - перша в серії бронзових плит, що позначають маршрут головного героя «Улісса», званий в середовищі фанатів «стежкою Блума». Звідси стартують екскурсії по місцях, пов'язаних з Джеймсом Джойсом, організовані дублінськими туристичними агенціями. Звідси ж ніхто не забороняє стартувати самостійно, поклавши в рюкзак важкий том «Улісса», який використовується в якості путівника [13].

Маршрут «Лотофаги» - похоронне бюро Ніколса розташоване на тому ж самому місці, що і при Джеймсі Джойсі. Від поштового відділення на Вестленд-роу залишилася зовнішня стіна, в якій колись знаходився вхід в поштове відділення. У ньому Блум отримав любовне послання. Зараз ці двері ведуть у касу залізничної станції Вестленд-роу [4].

Гідне завершення маршруту - аптека Sweny, яка дійсно $з$ того часу нікуди не переїхала. Нині, на ній навіть відновлена вивіска епохи Джойса [15]. 
Маршрут «Аїд» - шлях від будинку Падді Дігнама в Сендімаунті (будинок 9 по Ньюбрідж-авеню) до католицького кладовища 3 дивно назвою «Проспект» можна повторити на таксі [18]. Відповідна частина оповідання Джойса містить назви вулиць, по яких колись котилася скрипуча карета 3 містером Блумом, що їде на похорон шкільного товариша. Серед орієнтирів по дорозі - пам'ятник засновнику ірландської парламентської партії Чарльзу Стюарту Парнеллу [20]. Біля пам'ятника починається вулиця Парнелла, на якій знаходиться Центр Джеймса Джойса - музей, найцікавіший експонат якого - вже вище згадані двері будинку Леопольда Блума.

Маршрут «Еол» - редакція найбільшої щоденної газети Freeman’s Journal перебувала на Прінс-стріт, відразу за будівлею головної пошти Дубліна на О>коннел-стріт у світі Джойса. У сучасному світі це редакція Irish Independent на Міддл-Еббі-стріт [6]. А на О〉коннелстріт, можна зустріти бронзового Джеймса Джойса [9].

Куди відправитися далі? «У який же саме питний заклад?»- риторично запитував колись Ленехан і сам собі відповідав: «Даю свій голос за Муні!». На жаль, його рекомендацію розділити неможливо. Паб Mooneys не зберігся. Втім, це далеко не єдина назва пабу на сторінках «Улісса». У книзі Леопольд Блум одного разу поставив собі питання, чи можна перетнути місто Дублін, жодного разу не пройшовши повз пабу?

Маршрут «Лістрігони» - у пабі Davy Byrne’s на Дюк-стріт, сьогодні можна не тільки перекусити, але і як слід пообідати [3]. Якщо ви потрапите в цей паб 16 червня, в День Блума, то здивуєтеся, яка кількість клієнтів може вміститися в маленькому залі і тому, який відсоток відвідувачів замовляє страву під назвою «Блум спешіал», тобто сендвіч з сиром горгонзола і гірчицею до келиха бургундського. Сендвіч покладається різати тонкими скибочками. Про цей паб Леопольд Блум думав так: «Цілком пристойний заклад».

Гуляти по ірландській столиці можна нескінченно довго, але рано чи пізно будь-яка людина, будь то Улісс, Леопольд Блум або просто літературний турист, повинен повертатися на Ітаку, тобто до себе додому.

Прогулянка по георгіївському району Дубліна багато в чому пов'язана з ім'ям Оскара Вайльда. Хоча багато людей вважають, що Оскар Вайльд англійський письменник, адже він поїхав вчитися в знаменитий Оксфорд, де отримав бездоганний англійський акцент. Крім того, місце дії двох найбільш відомих його творів, «Кентервільський привид» $\mathrm{i}$ «Портрет Доріана Грея», ніяк не пов'язане з Ірландією. Проте, Оскар Фінгал О১Флагерті Вілс Вайлд народився 16 жовтня 1854 р. у Дубліні, у будинку №21 на вулиці Вестленд Роу. Сьогодні в цьому будинку знаходиться одне з літературних підрозділів Трініті-коледжу [90]. Буквально через дорогу розкинувся зелений парк Мерріон Сквер, крізь грати паркану якого проглядає пам'ятник Вайльду [14].

Багато туристів не знають, як Дублін пов'язаний з Дракулою адже всім відомо, що його прообраз, жорстокий князь Цепеш жив у Трансільванії. Однак Брем Стокер, який написав знамениту книгу, ніколи там не був. Він народився в столиці Ірландії і все життя говорив $з$ дублінським акцентом.

Рідний будинок Стокера знаходиться за адресою: 15, Marino Crescent. На невеликій будівлі сірого кольору немає ніякої таблички. Зате в кафе поруч можна побачити бюст автора і зображення вампірів на стінах [1].

«Замок Дракули» в Дубліні - це відносно нова пам’ятка. Він відкрився в грудні 2014 р. До нього була виставка Bram Stoker Dracula Experience, яка не користувалася популярністю. Тепер декорації оживляють актори і спецефекти. Дітям вхід дозволений починаючи з 14 років [2].

Ще однією причиною того, щоб відвідати Дублін - це знайти дім, де народився відомий на увесь свій письменник Джордж Бернард Шоу. Драматург народився 26 липня 1856 р. на околиці Дубліна в невеликому, але дуже затишному вікторіанському будинку на вулиці Сінг, де зараз знаходиться його будинок-музей. Він прожив тут всього 20 років, але цього стало цілком достатньо, щоб зрозуміти, яке було дитинство у майбутнього великого літератора. Внутрішнє оздоблення і атмосфера будинку Джорджа Бернарда Шоу були повністю відновлені, тому тут можна побачити іграшки, книги, сервізи і картини, які оточували маленького Бернарда. Будинок-музей відкритий для відвідування протягом року з вівторка по четвер 3 11:00 до 15:30, а також щосуботи з 14:00 до 17:00 [19]. Можна також замовити екскурсію, де вам розкажуть про те, чим займалася сім'я Шоу, і які витівки здійснював Бернард в підлітковому віці.

Узагальнюючи дослідження про ірландських письменників та їх внесок в літературні дестинації Великобританії слід зазначити, що вони відіграли важливу роль у розвитку літературного туризму. Ірландія подарувала Сполученому Королівству велике культурне надбання - дійсно величних письменників, а саме Оскара Вайльда, Джорджа Бернарда Шоу, Джеймса Джойса, Джонатана Свіфта, Брема Стокера, які прославляли не тільки свою батьківщину, але й сусідню країну. «Ставши на ноги» на рідній землі, більшість із творців вирушали у вільне «плавання» до Лондона, шукаючи розвитку, слави, визнання та кращого життя. 


\section{Список використаних джерел та літератури:}

1. Bram Stoker Signature URL: http://www.bramstoker.ie/index.php/ where-bram-s-birthplace

2. Castle Dracula Dublin URL: http://www.castledracula.ie/

3. Davy Byrne's pub URL: https://davybyrnes.com/

4. Dublin Pearse URL: https://www.irishrail.ie/station/dublin-pearse

5. Dublin Writers Museum. Visit Dublin URL: https://www.visitdublin. com/see-do/details/dublin-writers-museum

6. Freeman's Journal URL: http://m.joyceproject.com/

7. James Joyce (1882-1941) URL: https://www.joycetower.ie/our-stories/ james-joyce/

8. James Joyce Bridge. Bridges of Dublin URL: http://www. bridgesofdublin.ie/bridges/james-joyce-bridge

9. James Joyce Statue URL: https://www.tripadvisor.ru/Attraction Review-g186605-d2322360-Reviews-James_Joyce_Statue-Dublin_County_ Dublin.htm

10. James Joyce Tower \& Museum | Sandycove Dublin Ireland URL: https://www.joycetower.ie/

11. James Joyce: Exhuming bones and resurrecting house of The Dead URL: https://www.bbc.com/news/world-europe-50390837

12. Joyce Centre Dublin URL: https://web.archive.org/ web/20140424081801/http://jamesjoyce.ie/

13. Seven Eccles street URL: http://m.joyceproject.com/ notes $/ 040005$ seveneccles.html

14. Statue of Oscar Wilde URL: https://www.atlasobscura.com/places/ statue-of-oscar-wilde

15. Sweny's - The Dublin pharmacy featured in James Joyce's URL: http://sweny.ie/site/

16. Trinity Oscar Wilde Centre URL: https://www.tcd.ie/OWC/

17. День Блума в Ирландии URL: https://www.calend.ru/ holidays/0/0/1249/

18. Джеймс Джойс Улисс ; Аннотация URL: http://www.libed.ru/ knigi-nauka/925067-23-dzheyms-dzhoys-uliss-annotaciya-velikiy-irlandskiypisatel-dzheyms-dzhoys-1882-1941-stoit-istokov-vsey-moderni.php

19. Дом-музей Джорджа-Бернарда Шоу (Show birthplace) URL: http://aleksandrfridman.ru/countries/ireland/capitaldublin/\% D $0 \% 94 \%$ D $0 \%$ B E \% D $0 \%$ B C - \% D 0 $\%$ B C \% D $1 \% 83 \%$ D $0 \%$ B $7 \%$ D $0 \%$ B $5 \%$ D $0 \%$ B $9-\%$ D $0 \% 9$ $4 \%$ D $0 \%$ B $6 \%$ D $0 \%$ B E $\%$ D $1 \% 80 \%$ D $0 \%$ B $4 \%$ D $0 \%$ B $6 \%$ D $0 \%$ B $0-\%$ D $0 \% 91 \%$ D $0 \%$ B $5 \%$ D $1 \% 80 \%$ D $0 \%$ B D $\%$ D 0\%B0\%D1\%80\%D0\%B4\%D0\%B0-\%D0\%A8\%D0\%BE\%D1\%83.html

20. Памятник Чарльз Стюарт Парнелл в Дублине URL: https:// ru.depositphotos.com/85080662/stock-photo-monument-to-charles-stewartparnell.html

\section{Вікторія Бондар,}

студентка магістеріуму

Начіональний університет «Острозька академія»

\section{ІНКАЮЗИВНИЙ ТУРИЗМ У ТУРЕЧЧИНІ}

Існує велика різноманітність визначень поняття «доступний туризм». «Доступний туризм», також відомий як «туризм для всіх», «універсальний туризм», «інклюзивний туризм»- туризм і подорожі, доступні всім людям 3 обмеженими можливостями чи ні, включаючи людей з обмеженою рухливістю, слухом, зором, когнітивними або інтелектуальними та психосоціальними вадами, літніх людей та осіб з тимчасовими вадами». Останніми роками, разом 3 наданням іншого значення поняттю «інвалід», людей 3 обмеженнями розглядають як спільноту, яка має однакові права 3 іншими людьми в суспільстві і яка бореться за інтеграцію з суспільством у відповідності до цих прав, а не як пасивних та нужденних індивідів

Концепція інклюзивного туризму може бути цінним доповненням до родини термінів (наприклад, відповідальний туризм, соціальний туризм, доступний туризм), які складають це понятійне поле. Інклюзивний туризм визначається як «Трансформативний туризм, в якому маргіналізовані групи займаються етичним виробництвом або споживанням туризму та розподілом його переваг». У багатьох країнах можливості подорожі та проживання для людей з потребами у доступності є дуже обмеженими. Такі речі, які трапляються під час подорожі, як відсутність достатньої кількості кімнат, що дозволяють проїзд крісла-коляски, дефіцит обладнання, відсутність систем звукової сигналізації в підйомниках, продаж неправильних або незручних турів викликають проблеми у туристів 3 необхідністю доступності. Попит на туризм не є простим заходом для осіб, що мають потреби в доступності, оскільки передбачає такі послуги, як бронювання, проживання, трансфер та транспорт. Усі особи мають право користуватися послугами, які надає туристичний бізнес. Крім того, широко прийнято вважати, що бажання подорожі індивіда 3 обмеженими можливостями і людини без обмежень, є однаковим.

Зростає кількість людей, які мають інвалідність через старіння населення, будь-яке нещастя, таке як стихійне лихо чи аварія, і їм

(C) Вікторія Бондар, 2020 
потрібно подорожувати, сьогодні також можна побачити доступний туризм як нішевий напрямок у літературі. Світовий туристичний сектор зіткнувся $з$ попитом на туризм, очікуючи на кращі можливості доступу до транспорту, проживання, подорожей, турів, пляжів, ресторанів та туристичних автобусів. Люди з обмеженими можливостями та їх родини бажають віддавати перевагу туристичним продуктам, що мають ці особливості.

Фізична доступність, безумовно, є основною умовою надання доступності тим, хто має особливі потреби. Туристичні напрямки, готелі, транспортні засоби, пошук інформації для турів та бронювання чи придбання квитків потребують доступності. У ході дослідження Darcy зазначив, що 45\% учасників зауважили, доступність інформації для них важлива, оскільки, плануючи подорожі, люди 3 обмеженими можливостями ставляться до цього детальніше, ніж особи, які не є інвалідами. Інваліди дізнаються про свою подорож, беручи до уваги особливі потреби. Вимога щодо більшої доступності означає більше інформації, яка відповідає потребам цих клієнтів.

У своєму дослідженні Albayrak (2014) уточнила ергономічні проблеми, які виникають у людей з фізичною вадою в ресторанах туристичної індустрії; вона виявила, що люди з обмеженими фізичними можливостями не лише стикаються 3 проблемами, пов'язаними 3 фізичними особливостями, але також мають такі проблеми, як сором отримувати допомогу під час їжі, відчувають незручність від поглядів інших, нечутливої та недоброзичливої поведінки персоналу. Отже, розуміння поняття «туризм для всіх» має бути прийняте для того, щоб відповідати очікуванням доступності в управлінні дестинаціями з туристичною галуззю.

Коли доступний туризм розглядається як право, яке мають особи, це представляється необхідністю, щоб уряди мали виконати усі заяви щодо обслуговування доступного туризму. Тим не менш, необхідна умова, щоб люди могли використовувати право, яке вони мають, що залежить від усвідомлення цього питання та координації між урядом та приватним сектором. Туристична діяльність сьогодні $\epsilon$ необхідною потребою для людей. Для того, щоб відповідати очікуванням від цього важливого виду діяльності, слід прийняти норми, які можуть відповідати різним видам туристів і які можуть задовольнити потреби туристів.

Айше Нілай Евсіл пропонує цікавий тематичний випадок проблем, з якими стикаються користувачі на інвалідних візках в одній 3 найвідоміших туристичних визначних пам'яток Туреччини, на площі Султанахмет у Стамбулі. 125 респондентів зазначили, що у них були проблеми з тротуарами, пандусами, сходами та парковкою. Розмірковуючи про значення концепції «універсального дизайну», що базується на принципі справедливості, Евсіл, таким чином, зазначає, що цілі збереження та реставрації можуть суперечити цілям доступності для людей з обмеженими можливостями. По суті, відсутність доступності створює соціальну нерівність.

Разом з імплементацією положень у різних країнах, які не враховуються роками, люди з обмеженими можливостями почали більше подорожувати. У Туреччині та в розвинених країнах відповідно до важливості, що надається основним правам людини та свободи, було прийнято правове регулювання для того, щоб люди з обмеженими можливостями могли легше долучитися до соціального життя. Ці нормативно-правові акти є істотними як для орієнтації інвалідів на соціальне життя, так і для участі їх у туристичній діяльності. Сюди можна віднести 26-ту статтю Хартії основних прав, прийняту Свропейським Союзом, Закон про людей з обмеженими фізичними можливостями, прийнятий у 1990 році, та Закон про дискримінацію інвалідності - спрямований на те, щоб припинити дискримінацію, 3 якою стикаються багато людей з обмеженими можливостями, що відіграють важливу роль у туристичному секторі.

До слова, у Туреччині затверджено Конвенції Організації Об'єднаних Націй про права людей з інвалідністю, а також створення «Комітету туризму без обмежень для всіх» Асоціацією турецьких туристичних агентств (Türkiye Seyahat Acentaları Birliği / TÜRSAB) від 15 червня 2006 року, для виявлення незручностей, що виникають у цій місцевості, та допомоги вітчизняним та іноземним туристам $з$ обмеженими можливостями подорожувати до Туреччини без обмежень, можна оцінити як важливі кроки. Однак, незважаючи на існуючі правові норми, все ще існують проблеми щодо доступності в археологічні пам'ятки, музеї, міські центри, підприємства харчування, пляжі, підприємства розміщення та транспортні засоби.

Туреччина є туристичною країною, тобто вона зобов'язана великою часткою свого валового внутрішнього продукту (ВВП) своїй туристичній галузі та шукає шляхи отримання переваг в цьому висококонкурентному секторі. Крім того, країна зіткнулася з серйозною фінансовою кризою і намагається зміцнити свої конкурентні переваги. Тому доступний туризм виступає прекрасною можливістю для країни, особливо для іiі менш розвинених регіонів.

Історичний огляд законодавства про інвалідів в Туреччині показали, що Республіка Туреччина прийняла «Загальну Декларацію прав людини», «Декларацію про права інвалідів», а також в 1989 
році положення в «Свропейській соціальній хартії. У 2005 році був прийнятий і введений в дію закон Туреччини про інвалідність, який забезпечує дотримання зручностей у всіх громадських місцях і службах для інвалідів. У Туреччині в останні два десятиліття в законодавстві стали з'являтися спеціальні положення у формі рекомендацій. Які-небудь повноваження по застосуванню санкцій чітко не визначені, а тому застосування цих положень не може бути забезпечене. 3 прийняттям «турецького закону про інвалідність» Туреччина переживає перехід до держави, у якій забезпечуються права громадян-інвалідів.

\section{Список використаних джерел та літератури:}

1. Association of Turkish Travel Agencies (Türkiye Seyahat Acentaları Birliği/TÜRSAB). «Engelsiz Turizm». 2014. URL: www.tursab.org.tr/tr/ engelsiz-turizm

2. Council of Europe. «European Social Charter». 1961. URL: www. refworld.org/docid/3ae6b3784.html

3. Darcy S. Inherent complexity: Disability, accessible tourism and accommodation information preferences. Tourism Management. 2010. 31(6). P. 816-826

4. Darcy S., Dickson T. (2009) A Whole-of-Life Approach to Tourism: The Case for Accessible Tourism Experiences. Journal of Hospitality and Tourism Management, 16(1). P. 32-44.

5. United Nations. Universal Declaration of Human Rights. New York. 1948. URL: www.un.org/en/documents/udhr/index.shtml

6. United Nations. Declaration on the Rights of Disabled Persons New York. 1975. URL: www.ohchr.org/EN/ProfessionalInterest/Pages/ RightsOfDisabledPersons.aspx

7. World Tourism Organization Manual on Accessible Tourism for All: Principles. Tools and Good Practices. Module II: Accessibility Chain and Recommendations. UNWTO Madrid. 2015.

8. World Health Organization. «World report on disability». 2011. URL www.who.int/disabilities/world_report/2011/en/

\section{MİCT}

\section{СЕКЦі் 1}

АКТУАЛЬНІ ПРОБЛЕМИ ЗАРУБІંЖНОГО РЕГİОНОЗНАВСТВА

\section{Анастасія Мартинюк}

БОРОТЬБА ЗА ГЕНАЕРНУ РІВНІСТЬ У ШВЕЦІї

Віктор Лазарчук

ВІАНОСИНИ ЄВРОПЕЙСЬКОГО СОЮЗУ ТА

ШВЕЙЦАРСЬКОЇ КОНФЕАЕРАЦЇ̈ В УМОВАХ ВRЕХІТ ...7

\section{Свгеній Чопа,}

ВПЛИВ АЕЗІНТЕГРАЦІЙНИХ ПРОЦЕСІВ В КАТАЛОНІЇ

НА ВНУТРІШНЬОПОЛІТИЧНУ СИТУАЦІЮ В

КОРОЛІВСТВI ІСПАНІЯ

Нікіта Беляев

ІНІЦІАТИВА «ОАИН ПОЯС , ОАИН ШЛЯХ» ЯК НОВІТНЯ ФОРМА ЕКОНОМIЧНОÏ ВЗАЄMOAIÏ KHP TA ЄC

Олександр Шама

ЗМІНА СУСПІЛЬНОГО СТАНОВИЩА ГАЛИЦЬКОЇ

ШЛЯХТИ У ХІХ - НА ПОЧАТКУ ХХ СТ

Ігор Вознюк

ПРОБЛЕМИ ВПРОВААЖЕННЯ ПЛАНУ

АОНАЛЬАА ТРАМПА «МИР ЗАРААИ ПРОЦВІТАННЯ» 2

Вікторія Гордійчук

РОЛЬ ТЕРИТОРІАЛЬНИХ СУПЕРЕЧОК У ВІАНОСИНАХ ЯПОНІї ТА ПІВАЕННОÏ KOPEÏ

СЕКЦіંЯ 2

\section{СУЧАСНІ ТЕНДЕНЩІї̈ РОЗВИТКУ} МІЖЖНАРОДНОГО ТУРИЗМУ

Анастасія Машенцова

РОЗВИТОК ТУРИЗМУ АЛЯ РІЗНИХ СОЦІААЬНИХ ГРУП

У ПОРТУГАЛІЇ

Анастасія Морозецька

ГАСТРОНОМІЧНИЙ ТА ВИННИЙ ТУРИЗМ В ІТААЇ

У XXI CTOЛITTI 
Анна Белєнкова

ТУРИСТИЧНА ІНАУСТРІЯ КОРЕЙСЬКОЇ РЕСПУБЛІКИ ....43

Анастасія Бонь

ВИАОВИЩНО-РОЗВАЖАЛЬНІ ПРОГРАМИ

В ШОТААНАІЇ ЯК ОАИН З РІЗНОВИАІВ НОВИХ

ВИАІВ ТУРИЗМУ

Вікторія Аіщук

РОЗВИТОК ІНАУСТРЇ̈ КУРОРТНО-ПАЯЖНОГО

ТУРИЗМУ НА КАНАРСЬКИХ ОСТРОВАХ

В XXI СТОЛITTI ......

Владислав Мойсеєць

БРЕНАОВА ТА МАРКЕТИНГОВА СТРАТЕГІЯ

ТУРИСТИЧНОГО РИНКУ УКРАЇНИ

\section{Ірина Партико}

ПРОБЛЕМИ ТА ПЕРСПЕКТИВИ РОЗВИТКУ

ЛІКУВАЛЬНО-ОЗАОРОВЧОГО ТУРИЗМУ

У ШВЕЙЦАРСЬКІЙ КОНФЕАЕРАЦІЇ

Олег Височанський

ВПЛИВ ОЛМПІЙСЬКИХ ІГОР НА РОЗВИТОК ТУРИЗМУ

В КРАЇНАХ ПРОВЕАЕННЯ

Олександра Печерська

ТЕНАЕНЦІЇ РОЗВИТКУ ФЕШН-ТУРИЗМУ

B XXI CTOЛITTI

Олександра Фомін

РЕЛІГІЙНИЙ ТУРИЗМ В ОАЕ В ХХІ СТОЛІТТІ

ПРОБЛЕМИ ТА ПЕРСПЕКТИВИ

Олена Герасимчук

ТЕМАТИЧНІ ПАРКИ КУРОРТУ ТОКYО DISNEY RESORT ... 76

Олена Контаріз

ПРОБЛЕМИ І ПЕРСПЕКТИВИ РОЗВИТКУ ТУРИЗМУ

У ФІНЛЯНАІЇ .

Яна Катрецька

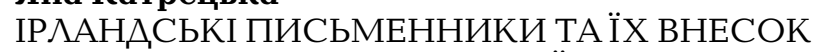

У ЛІТЕРАТУРНІ АЕСТИНАЦІЇ ВЕЛИКОБРИТАНІЇ

Вікторія Бондар

ІНКЛЮЗИВНИЙ ТУРИЗМ У ТУРЕЧЧИНІ 
Наукове видання

\section{МІЖНАРОДНІ ВІДНОСИНИ І ТУРИЗМ: СУЧАСНІСТЬ ТА РЕТРОСПЕКТИВА}

Збірник матеріалів Десятої всеукраїнської науково-практичної конферениї студентів та молодих учених

28 травня 2020 р., м. Острог

Buпуск 10

Дякуємо за допомогу в підготовці конференцї̈ колективу
кафедри краӥнознавства

Відповідальний секретар і упорядник Олександра Фомін Комп'ютерна верстка Наталії Крушинської

Контакти: Факультет міжнародних відносин

Адреса: 35800 вул. Семінарська, 2, м. Острог, Рівненська обл.,

+380365430832 e-mail: studconference@ukr.net

Формат 42х30/4. Ум. друк. арк. 5,7. Наклад 50 пр. Зам. № 39-20.

Папір офсетний. Друк цифровий. Гарнітура «TimesNewRoman».

Оригінал-макет виготовлено у видавництві

Національного університету «Острозька академія»,

Україна, 35800, Рівненська обл., м. Острог, вул. Семінарська, 2.

Свідоцтво суб' єкта видавничої справи РВ № 1 від 8 серпня 2000 року.

Виготовлено ФОП видавець Свинарчук Р. В.

Свідоцтво суб’єкта видавничої справи РВ № 27 від 29 липня 2004 року.

Тел. +3806868358000, e-mail: 35800@ukr.net 